\title{
Sedimentology and Ichnology of Upper Montney Formation Tight Gas Reservoir, Northeastern British Columbia, Western Canada Sedimentary Basin
}

\author{
Edwin I. Egbobawaye \\ Department of Earth and Atmospheric Sciences, University of Alberta, Edmonton, Canada \\ Email: egbobawayeiii@gmail.com
}

How to cite this paper: Egbobawaye, E.I. (2016) Sedimentology and Ichnology of Upper Montney Formation Tight Gas Reservoir, Northeastern British Columbia, Western Canada Sedimentary Basin. International Journal of Geosciences, 7, $1357-$ 1411.

http://dx.doi.org/10.4236/ijg.2016.712099

Received: January 19, 2016

Accepted: December 23, 2016

Published: December 28, 2016

Copyright (๑) 2016 by author and Scientific Research Publishing Inc. This work is licensed under the Creative Commons Attribution International License (CC BY 4.0).

http://creativecommons.org/licenses/by/4.0/

\section{Abstract}

Several decades of conventional oil and gas production in Western Canada Sedimentary Basin (WCSB) have resulted in maturity of the basin, and attention is shifting to alternative hydrocarbon reservoir system, such as tight gas reservoir of the Montney Formation, which consists of siltstone with subordinate interlaminated very fine-grained sandstone. The Montney Formation resource play is one of Canada's prime unconventional hydrocarbon reservoir, with reserve estimate in British Columbia (Natural Gas reserve $=271 \mathrm{TCF})$, Liquefied Natural Gas $(\mathrm{LNG}=12,647$ million barrels), and oil reserve (29 million barrels). Based on sedimentological and ichnological criteria, five lithofacies associations were identified in the study interval: Lithofacies F-1 (organic rich, wavy to parallel laminated, black colored siltstone); Lithofacies F-2 (very fine-grained sandstone interbedded with siltstone); Lithofacies F-3A (bioturbated silty-sandstone attributed to the Skolithos ichnofacies); Lithofacies F-3B (bioturbated siltstone attributed to Cruziana ichnofacies); Lithofacies F-4 (dolomitic, very fine-grained sandstone); and Lithofacies F-5 (massive siltstone). The depositional environments interpreted for the Montney Formation in the study area are lower shoreface through proximal offshore to distal offshore settings. Rock-Eval data (hydrogen Index and Oxygen Index) shows that Montney sediments contains mostly gas prone Type III/IV with subordinate Type II kerogen, TOC ranges from $0.39-3.54$ wt\% with a rare spike of 10.9 wt\% TOC along the Montney/Doig boundary. Vitrinite reflectance data and Tmax show that thermal maturity of the Montney Formation is in the realm of "peak gas" generation window. Despite the economic significance of the Montney unconventional "resource-play", however, the location and predictability of the best reservoir interval remain conjectural in part because the lithologic variability of the optimum reservoir lithologies has not been 
adequately characterized. This study presents lithofacies and ichnofacies analyses of the Montney Formation coupled with Rock-Eval geochemistry to interpret the sedimentology, ichnology, and reservoir potential of the Montney Formation tight gas reservoir in Fort St. John study area (T86N, R23W and T74N, R13W), northeastern British Columbia, western Canada.

\section{Keywords}

Montney Formation, Sedimentology, Ichnology, Tight Gas Reservoir, Oil and Gas, Petroleum Geology, British Columbia, Western Canada Sedimentary Basin

\section{Introduction}

The Montney Formation is the basal stratigraphic unit of the Triassic succession in the subsurface of western Canada. It rests, unconformably in most areas, upon carbonate or mixed siliciclastic-carbonate strata of Carboniferous to Permian age [1] [2] [3] [4]. The succession was deposited in a west-facing, arcuate extensional basin on the western margin of Pangaea [4] [5] [6]. The Montney Formation is a primary focus of tight gas exploration in western Canada because: 1) it is a source rock rich in organic matter [7] which lies within gas generating thermal maturity window, and contains gas prone Type II/III kerogen; 2) the present study shows that the kerogen of the Montney Formation in the study area also comprises Type III/IV kerogen (TOC range from 0.34 - 4 $\mathrm{wt} \%$; and upto $8.2 \mathrm{wt} \%$ TOC are rare, but present); 3) it has a reservoir thickness up to 320 meters in northeastern British Columbia; 4) it hosts substantial volumes of unconventional gas, (Natural Gas reserve $=271 \mathrm{TCF})$, Liquefied Natural Gas $(\mathrm{LNG}=12,647$ million barrels) and oil reserve (29 million barrels) according to BC Ministry of Energy, Mines and Natural Gas report [8]; and 5) porosity range from $2 \%-10 \%$, and sporadically $>10 \%$ in some intervals where facies heterogeneity and trace fossils burrows, dolomite dissolution, or feldspar leaching have resulted in the formation of secondary porosity. These criteria make the Montney Formation an unconventional resource play with high potential within the Fort St. John study area (T86N, R23W and T74N, R13W), northeastern British Columbia (Figure 1). However, despite strong economic interest in unconventional silt-hosted hydrocarbon reservoirs within this stratigraphic interval, the geology, geochemistry, mineralogy and sedimentology have not been adequately characterized.

The Montney Formation consists of siltstone, very fine-grained sandstone, bioclastic packstone/grainstone (coquina, in Alberta) [4] [5], interlaminated, interbedded, dolomitic silty-sandstone [9] [10]. The Lower Triassic Montney Formation is separated by an unconformity from the underlying Permian Belloy Formation [11] [12]. The unconformity along the Permian-Triassic boundary has been interpreted by [1] [5] [13] to be related to a global eustatic sea level fall. The global eustatic fall was related to the amalgamation of Pangaea Supercontinent, and was followed by a protracted Late 


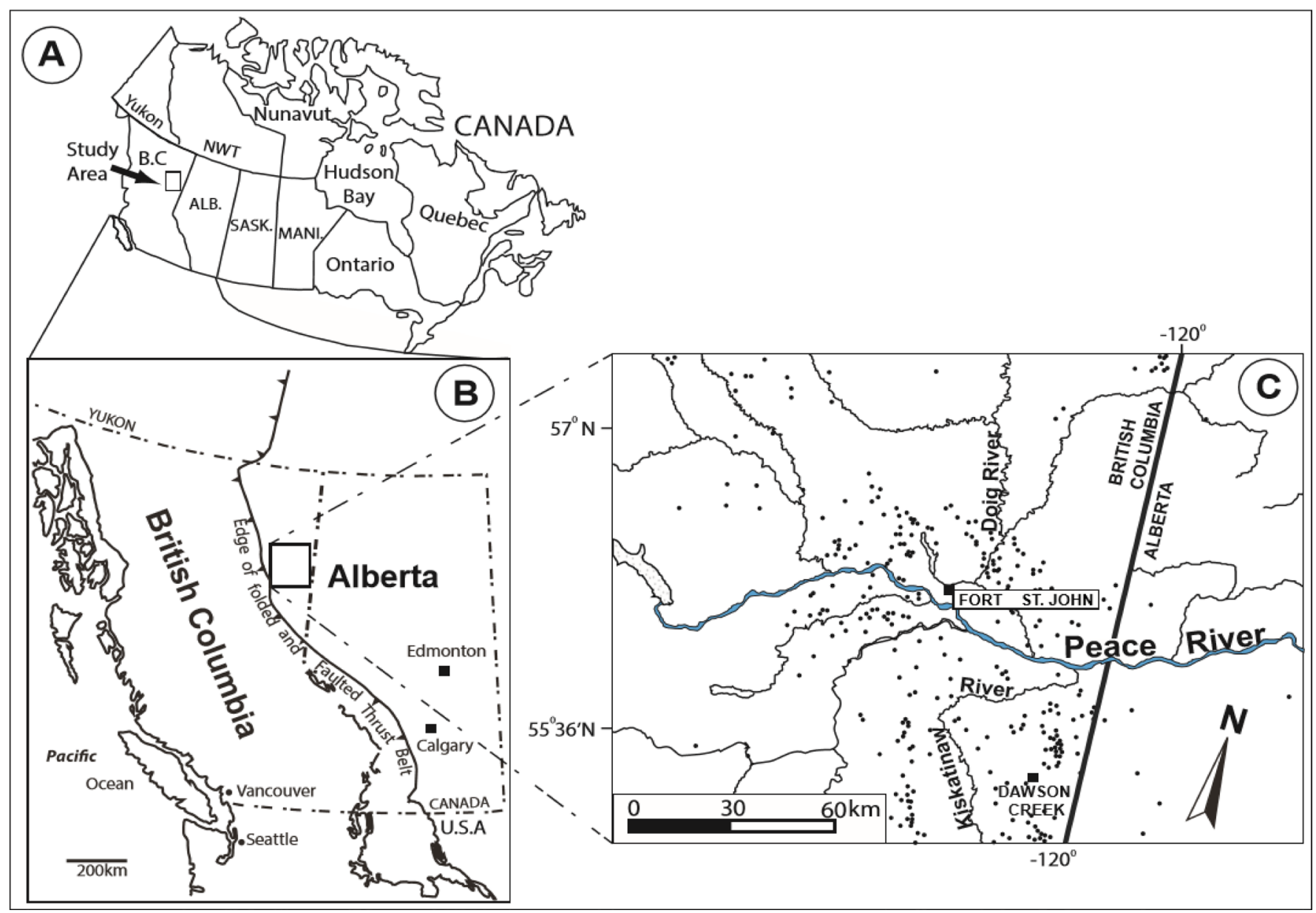

Figure 1. (A) Map of Canada showing provinces; (B) shows tectonic deformation and structure in Western Canada Sedimentary Basin [14]; (C) shows location map of study area in northeastern British Columbia. The black dots represent drilled wells.

Permian transgression that continued into the Triassic period [13]. The transgression was accompanied by anoxic conditions that induced profound environmental change [14], and may have severely increased levels of greenhouse gases [15] [16] [17]. These were the primary factors that contributed to the Late Permian-Triassic extinction crises, the largest extinction episode in geologic history [4] [13].

The Montney Formation is separated from the overlying Doig Formation by a strongly radioactive, high gamma ray (GR) reading on well logs (Figure 2), and phosphate rich interval known informally as the "Doig Phosphate Zone" [3] [18]. This boundary is an erosional surface, and has the same paleomagnetic record of normal polarity, which likely corresponds to the normal polarity interval MT2 in the bottom of the Anisian age that starts at $\sim 245 \mathrm{Ma}$ [19]. The Montney/Doig boundary is locally represented by a coplanar Trypanites-Glossifungites demarcated discontinuity surface (Figure 3 and Figure 4), which is correlatable on a regional scale [10] [19] [20]. The outcrop equivalent of the Montney Formation is the Grayling and Toad formations in northern British Columbia; Sulphur Mountain Formation in British Columbia, the Grayling and Toad formations south of the Peace River area in Alberta [3] [6] [21]. 


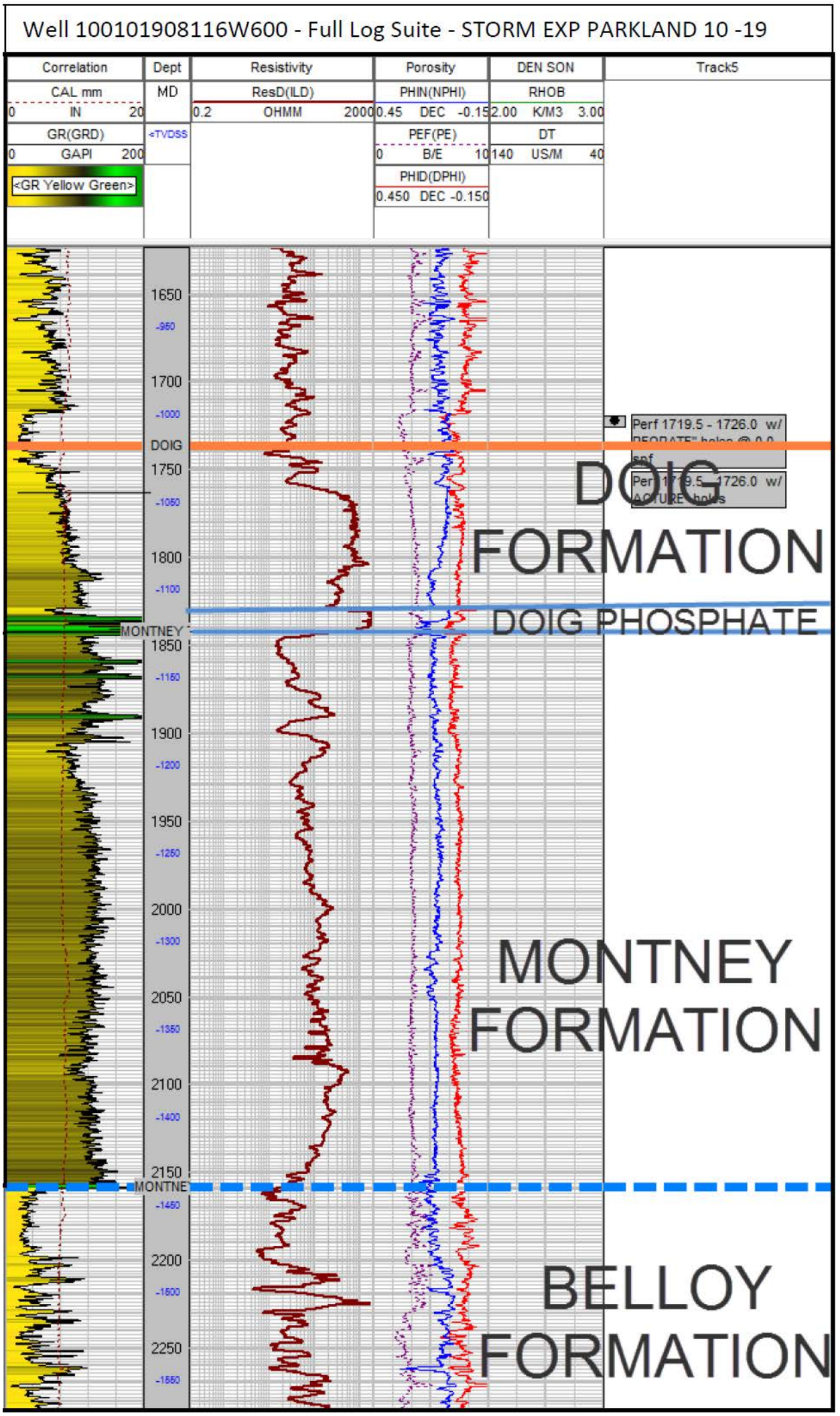

Figure 2. Type Log of the Montney Formation in the study area, northeastern British Columbia, Western Canada Sedimentary Basin (WCSB), adapted from [22]. 
Location: d-39-F/93-P-9 \#1

 grain size class

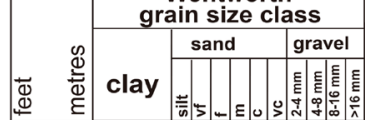

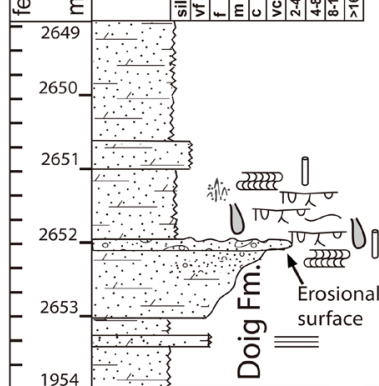

$-1954 \frac{\because\}\}}{\because \cdots\}}$

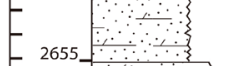

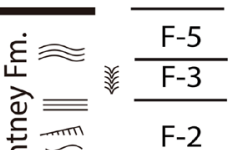

- $2 6 5 6 \longdiv { \square }$

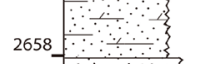

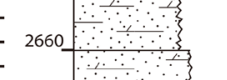

$266120\}$

$2662 \therefore$

$-2663(\because \because\}$

2664

$=2664$

$F^{2665}$

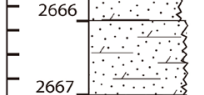

$\because\}$

${ }^{2668} \because 3$

2669

2670

2671

$2671 \square$

$2672 \because \because\}$

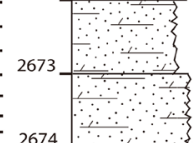

总而西

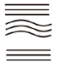

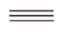

=

$\overline{\bar{\equiv}}$

$\equiv$

$\stackrel{\text { min }}{\underline{\underline{\underline{m}}}}$

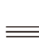

F-

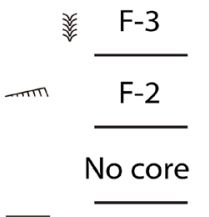

$\overline{\overline{\underline{ }}}$

$\overline{\bar{\equiv}}$

F-1

$\overline{\overline{ }}$

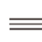

$\equiv$

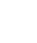

F-1

F-2

$F-3$

F-2

-1

F-3

F-2

o core

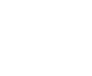

F-3

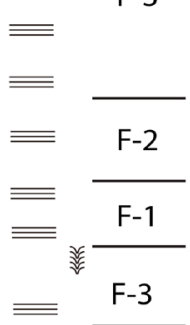

Location: d-39-F/93-P-9 \#2

\begin{tabular}{|l|l}
\hline & Wentworth
\end{tabular} grain size class

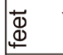

clay

sand

gravel

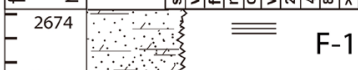

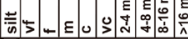

- $2675-\because\}$

[ 2676$] \quad \ldots$

-

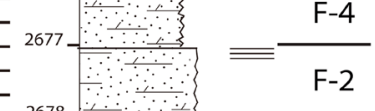

- 2678 - $\because \because 3$

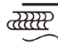

-

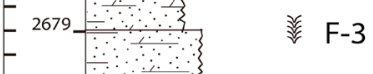

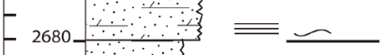

-

- 2681 의

$\because \equiv$

- 2682 - $\because \because \because\}$

F-1
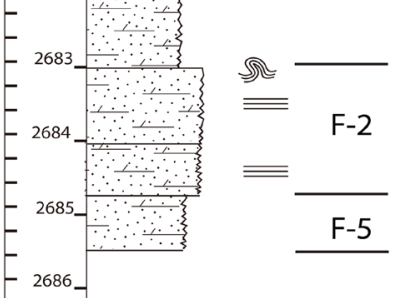

$-2686$

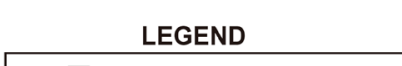

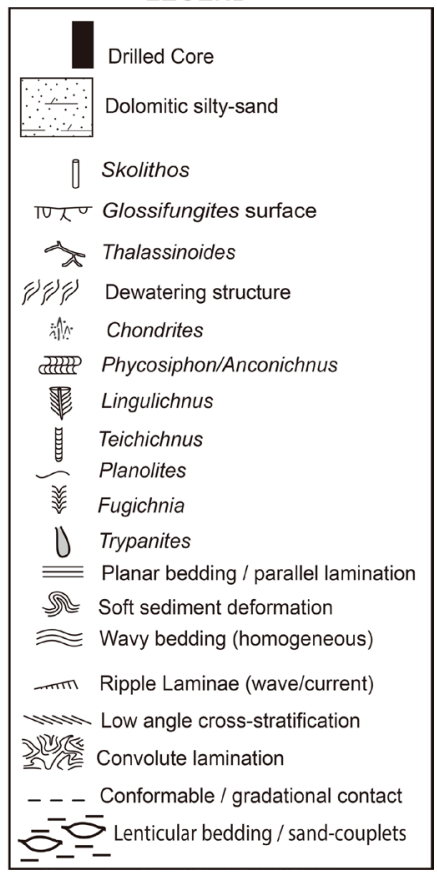

Figure 3. Logged core (well: d-39-F/93-P-9) showing lithofacies of the Montney Formation, and the overlying erosional contact of Glossifungaties - Trypanites surface demarcating the overlying Doig Formation from the Montney Formation in the subsurface of northeastern British Columbia. 

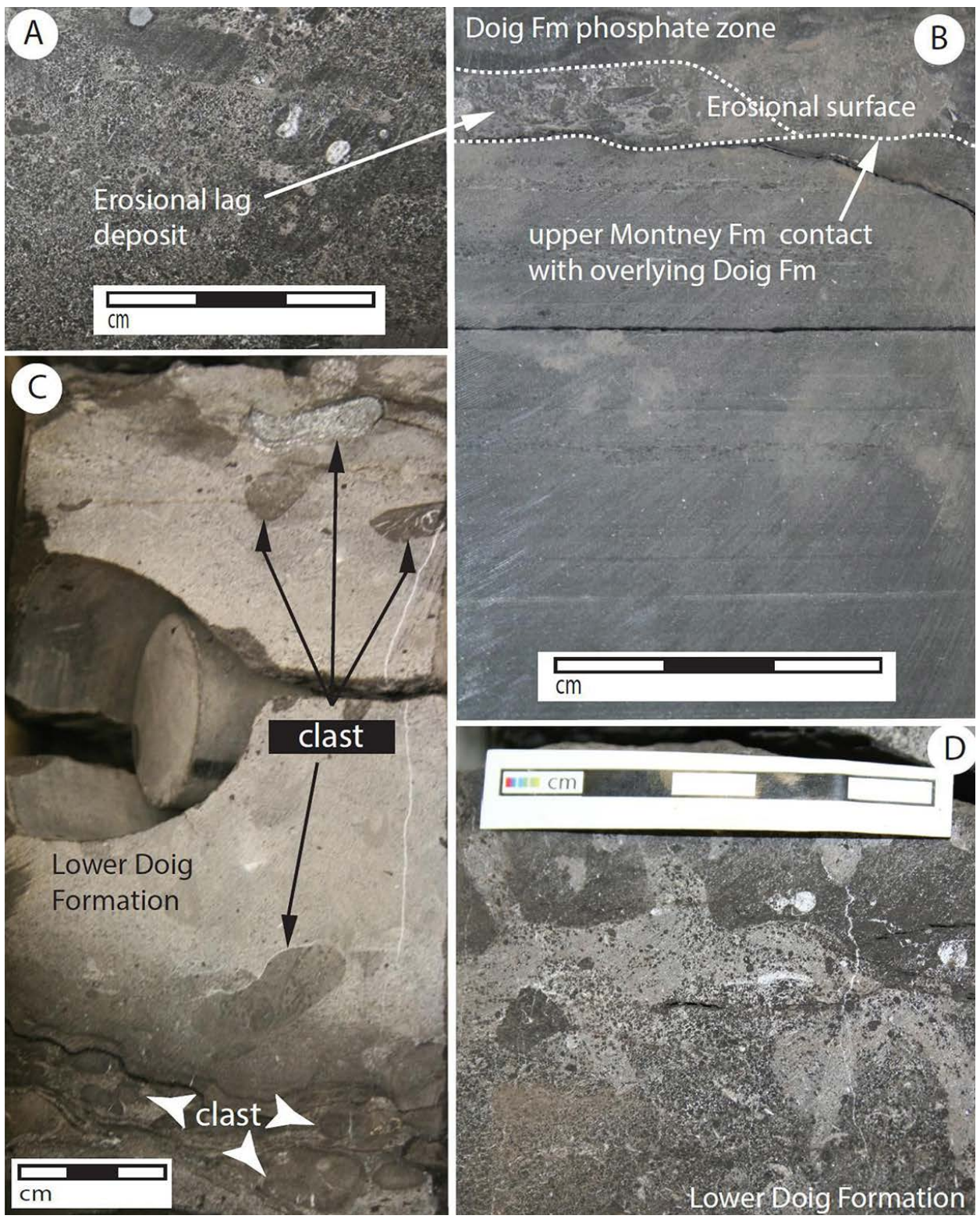

Figure 4. (A) Erosional lag deposit showing pebble clast along the Montney/Doig Formation boundary; (B) shows the Montney Formation and the overlying Doig Formation separated by erosional surface; (C) lag, clast of the Lower Doig Formation along the Doig/Montney boundary; (D) discontinuity surface along the Montney/Doig boundary.

In west-central Alberta, the Montney Formation has been reported by [23] to include turbidite channel lob complexes interpretive of mass wasting processes caused by Early Triassic (Smithian/Dienerian) global eustatic sea level fall. Within the study area in northeastern British Columbia, there is no evidence of turbidites channel lobe complexes associated with the (Smithian/Dienerian) global eustatic sea level fall.

This paper synthesizes the sedimentology, ichnology, and Rock-Eval geochemistry of the Upper Montney Formation in relation to tight gas reservoir characterization to decipher the depositional characteristics, reservoir potential and optimum reservoir li- 
thologies of the Monetney Formation in Fort St. John study area (T86N, R23W and T74N, R13W), northeastern British Columbia, Western Canada (Figure 1).

\section{Study Area and Methodology}

Based on analyses of paleomagnetic data, paleolatitude and paleoclimatic zonation [24], and fauna record [12], the Western Canada Sedimentary Basin (WCSB) during the Triassic time was situated at approximately $30^{\circ} \mathrm{N}$ paleolatitude [24]. The paleoclimate reconstruction suggests that the paleoclimate may have ranged from sub-tropical to temperate [11] [12] [24]. The region has been interpreted to be arid during the Triassic, and was dominated by westerly winds from the west [1] [24].

In Alberta and British Columbia, Triassic sediments were deposited in a central sub-basin known as the Peace River Embayment, which extended eastward from the Panthalassa western ocean onto the North American craton [1]. During the Triassic period, the Peace River Embayment was a low mini basin associated with minor fault block movement caused by a broad downwarp, which resulted in the rejuvenation of structural deformation within the Monias areas of southwest Fort St. John, British Columbia [1] [25]. Stratigraphically (Figure 5), the Triassic Montney Formation is Griesbachian to Spathian in age [21]. The Triassic succession thicken westward [1], and rests unconformably in most areas, upon the Belloy Formation in outcrop of northeastern British Columbia; Carboniferous in parts of northeastern British Columbia and Alberta; and Fantasque Formation in outcrop at Williston [21]. The thickness of Triassic deposit is about 1200 meters in the western-most outcrop in the Rocky Mountain Foothills [26]. The thickness of the Montney Formation within the Fort St. John study area in the subsurface varies in the east along British Columbia/Alberta boarder boundary and to the western portion of British Columbia (Figure 6). The Montney Formation structure map (Figure 7) indicates higher paleostructure in the east and low in the western portion of the study area. The structural tilt shows a depositional thinning to the east and

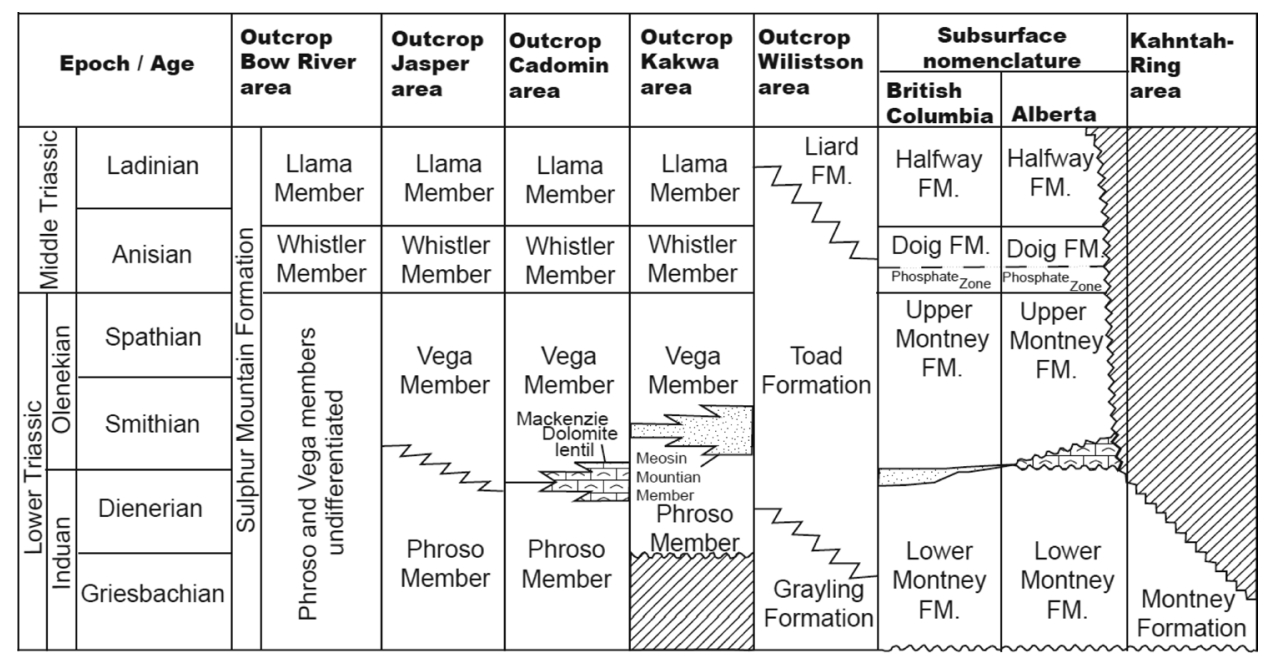

Figure 5. Stratigraphic chart showing Lower and Middle Triassic deposits and a correlation of outcrop with coeval subsurface strata in the western Canada Sedimentary Basin [21]. 


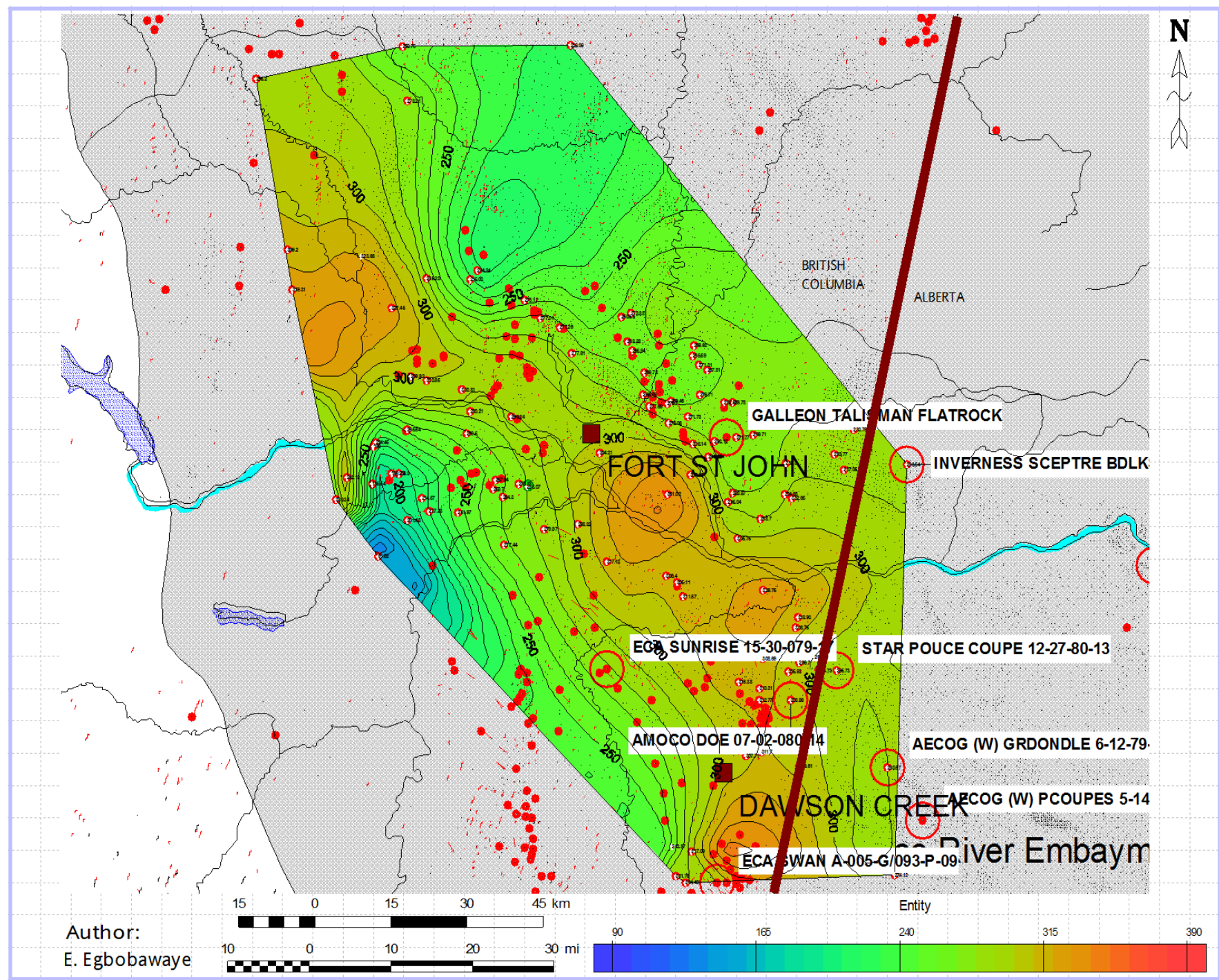

Figure 6. Isopach map of the Montney Formation showing the trends of thickness in northeastern British Columbia and northwestern Alberta.

north due to erosional removal. Isopach map of the Montney Formation indicates a maximum thickness of approximately 320 meters in the study area of northeastern British Columbia (Figure 6).

Drill cores of the Montney Formation from northeastern British Columbia were logged to assess sedimentological, ichnological and facies characteristics at the Charlie Lake Core Facility, British Columbia Oil and Gas Commission. Lithologic features and accessories, sedimentary texture, sedimentary structure, the nature of bedding contacts, and lithofacies were compiled in detail (Figures 8-10). Samples were collected from cores for thin-section petrography, X-ray diffraction (XRD) analysis, scanning electron microscopy (SEM) analysis, and Rock-Eval geochemistry. XRD analysis is essential in fine-grained sediments analysis, and it allows moderately accurate determination of the amount of magnesium substitution in calcite or dolomite lattices [27]. Thin-sections 


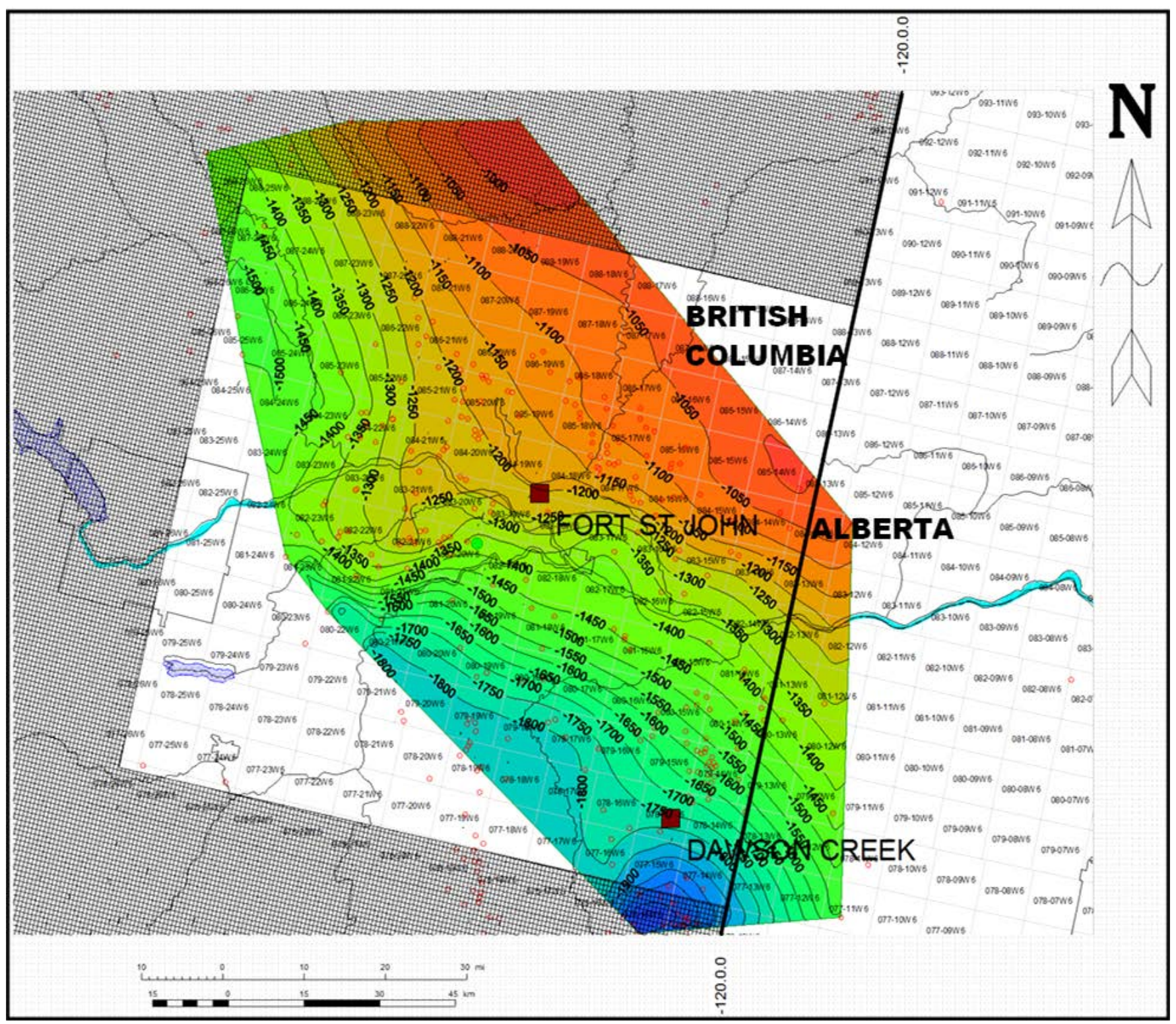

Figure 7. Map of study area showing structure contour map of the Montney Formation in northeastern British Columbia, Western Canada Sedimentary Basin (WCSB). The structure map shows structural tilting as evident by the increasing elevation eastward, which indicates that sediment source area was from the east, and sediments prograded westward.

were prepared with blue-dye epoxy to highlight porosity and examined with petrographic microscope in accordance with the method of thin-section petrography originally developed by [28], and were examined petrographically for textural characteristics, mineralogical composition, and porosity analyses. Thin-section petrography was used to determine grain sizes and sorting. Zones showing distinct features were photographed and analyzed.

Samples were crushed into powder using a pulverized shatter-box machine at the University of Alberta's Rock Crushing Facility. Samples were sent to Geological Survey of Canada and Chesapeake Energy Corporation, Oklahoma City, USA, for Rock-Eval 


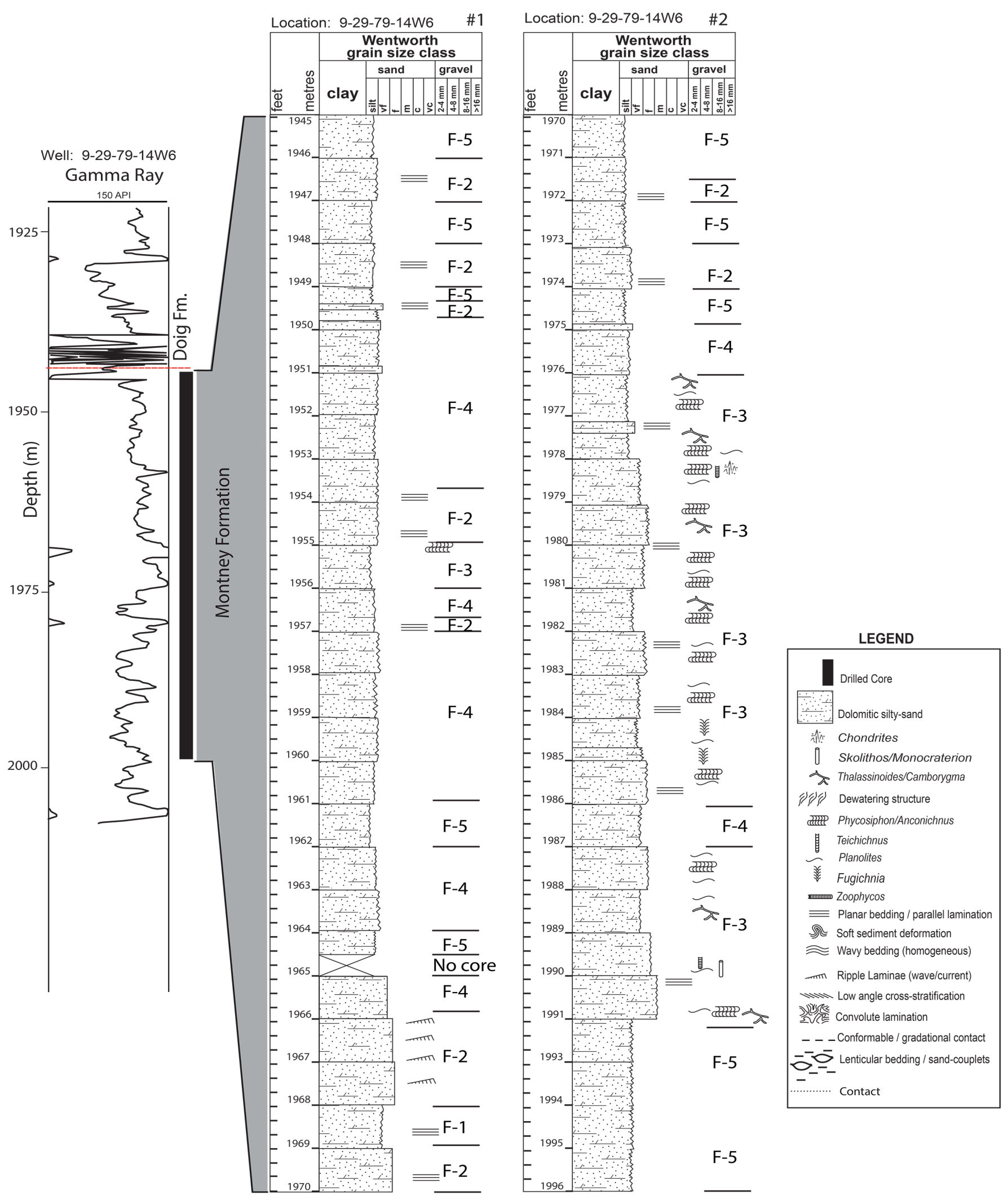

Figure 8. Gamma-ray log correlated with logged core (well: 2-29-79-14W6) showing lithofacies of the Montney Formation, northeastern British Columbia. 


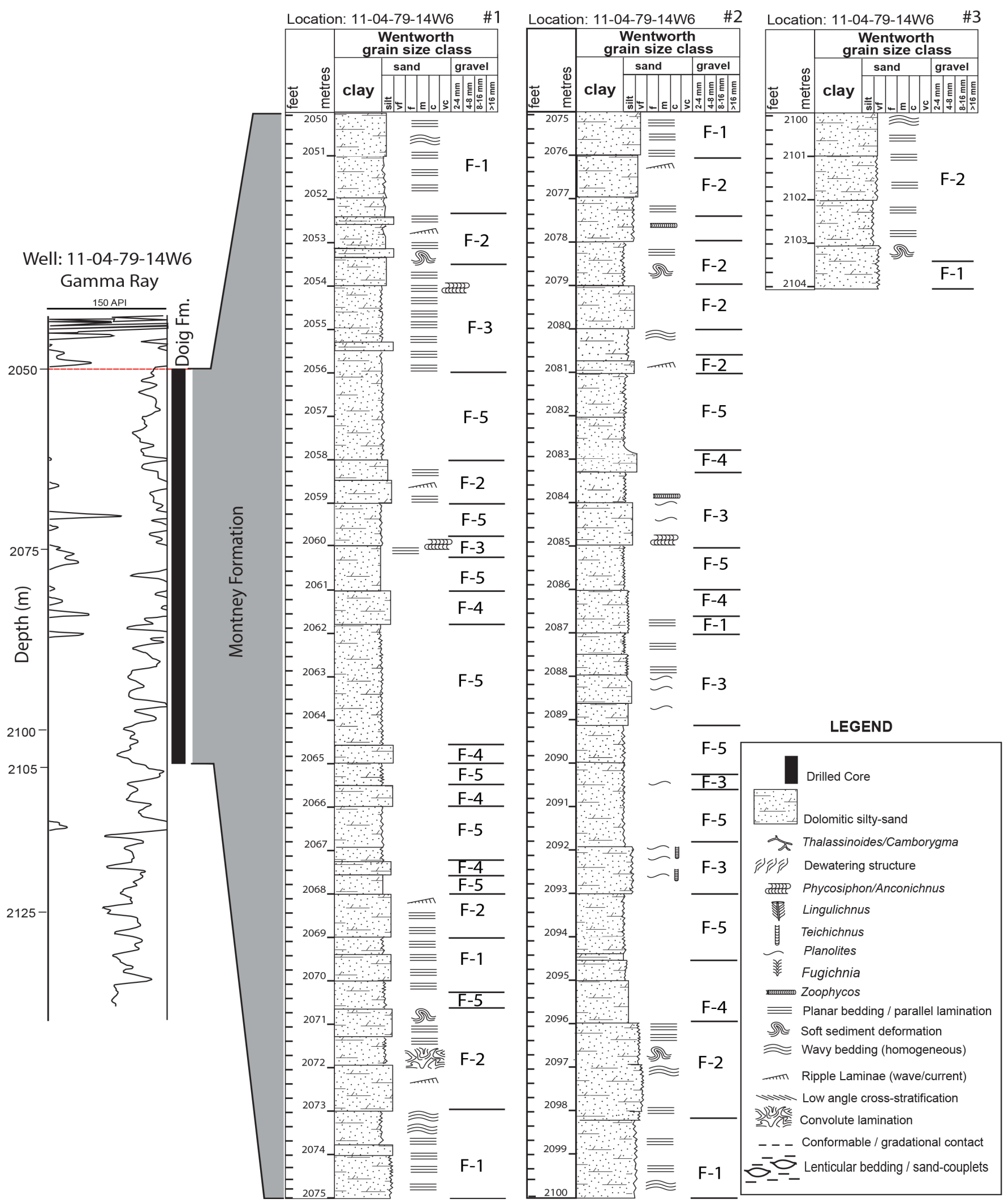

Figure 9. Gamma-ray log correlated with logged core (well: 11-04-79-14W6) showing lithofacies of the Montney Formation, northeastern British Columbia. 


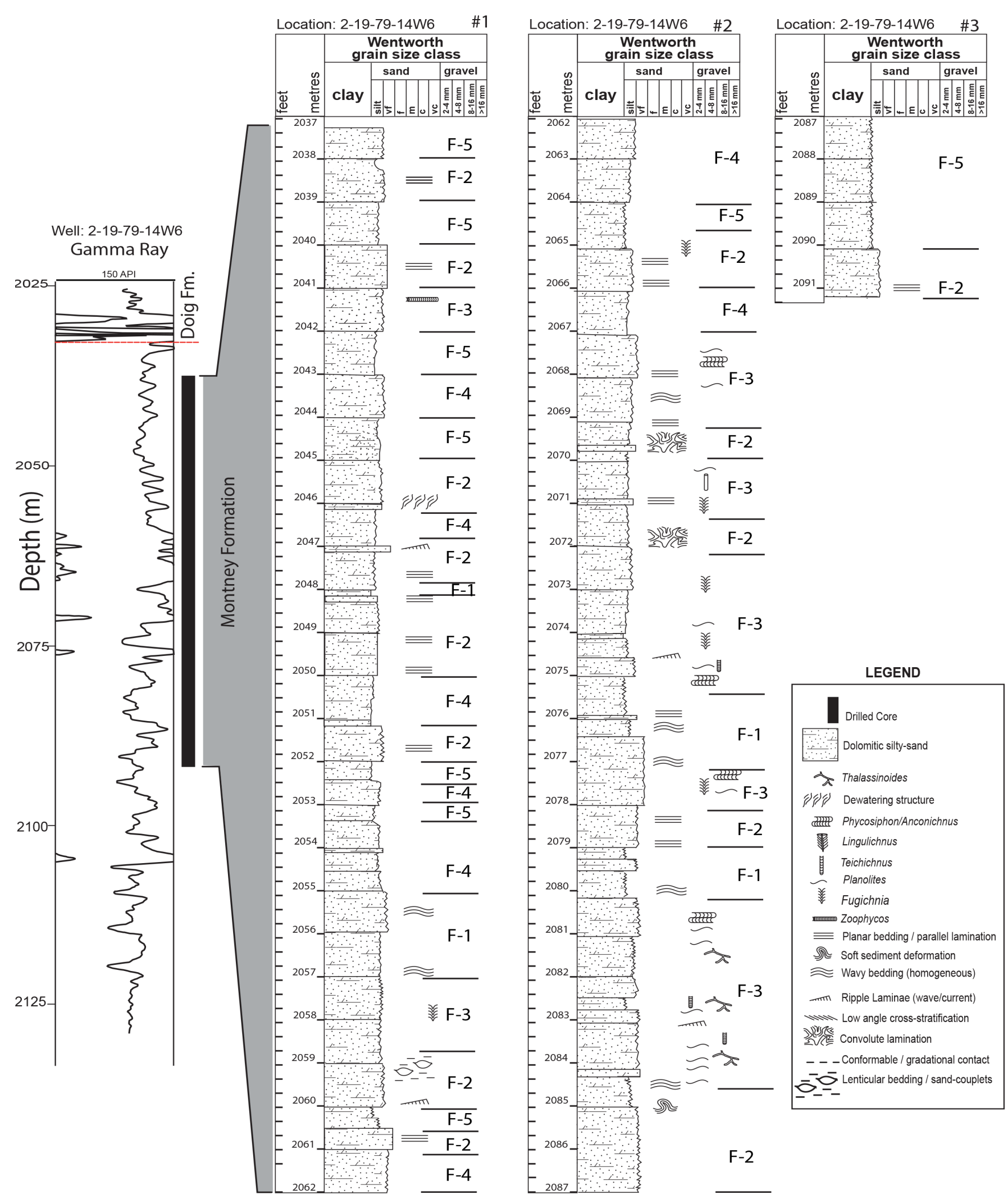

Figure 10. Gamma-ray log correlated with logged core (well: 2-19-79-14W6) showing lithofacies of the Montney Formation, northeastern British Columbia. 
analyses with additional geochemistry data from B.C Oil and Gas Commission. Ichnological study of the core samples involves recording and identification of ichnogenera, ichnofossil assemblages, distribution and paucity of trace fossils. Ichnofossils, lithofacie and depositional characteristics were integrated and used to interpret the paleoenvironments within the study interval.

\section{Facies Analysis}

[29] first introduced the concept of facies into the geological literature to describe a body of rock with specified biological characteristics in the Jura Mountains of Europe. Although the original definition of a facies was very concise from its inception, however, several ideologies of what constitute a facies have been proposed [30] [31], and the usage of the term facies has been a subject of debate for several decades [30] [31]. The core meaning of a facies with respect to a distinctive rock unit that forms under certain conditions of sedimentation, depicting a particular depositional process or specific depositional characteristics [32] remain central to the term facies. The facies concept is the building block of modern stratigraphy [32], and sequence stratigraphy. This paradigm led to descriptive rock attributes independent of time connotation to signify observable physical, chemical, and biological characteristics of rocks that aid objective description and differentiation of facies [32]. As a result, different facies schemes are used depending on the particular characteristics under consideration, or the scale of analysis [30] [31].

\subsection{Lithofacies}

The term lithofacies is a distinctly mappable subdivision of a stratigraphic unit based on a consideration of lithology, depositional features, petrological, and chemical characteristics of the rock distinguished from the underlying and overlying stratigraphic units or adjacent subdivisions within the rock record.

\subsection{Ichnofacies}

Trace fossils (animal tracks, trails, burrows, excavation, etc.) represents the vestiges of animal behavior in responds to stimuli within their environments, such as net sedimentation rates, salinity, oxygenation, temperatures, turbidity and a host of other environmental parameters [33]. The fundamental utility and strengths of the ichnofacies concept lies in its ease of interpretation with classical physical sedimentological facies analysis and its adherence to Walther's Law [34]. The overall behavior and coping strategies of animals are controlled by the prevailing physiochemical conditions of the environment [33]. Trace fossil morphology, resulting from the interaction of animals with sedimentary substrates, and subsequently preserved in the rock record become interpretive tool when integrated with physical sedimentary structure, and are invaluable in delineation of depositional environments [33] [34].

\subsection{Results of Facies Analysis in This Study}

Based on sedimentological and ichnological criteria from examination of Montney 
Formation cores in the study area, five lithofacies associations were identified: Lithofacies F-1, Lithofacies F-2, Lithofacies F-3, Lithofacies F-4, and Lithofacies F-5. Detailed description and interpretation are presented below. Sedimentological and ichnological parameters were integrated in the interpretation of depositional environments for the Upper Montney Formation. Trace fossils recorded in this study from cores are described in detail in Table 1. The small-scale lithofacies scheme developed herein (F1 through F5) help to associate genetically related facies, which were interpreted cogenetically. A summary of the sedimentary facies scheme used in this study is shown in Table 2. Specific interpretations for the depositional environments for the facies were

Table 1. Trace fossils description reported from the studied cores in the Upper Montney Formation, northeastern British Columbia.

1) Chondrites isp. Erected by Sternberg [35]. It is a dendritically complex burrow system, consisting of asymmetrical and branching smooth-walled tunnels. The Chondrites tunnels have a circular cross-section view.

2) Cruziana. Erected by Alcide D’Orbigny [36]. The burrow consists of elongate, and bilaterally symmetrical morphology. The burrow is preserved along bedding planes, with a sculpture of repeated striations that are mostly oblique to the long dimension.

3) Fugichnia. Erected by Simpson [37]. The burrow is an escape structure, which has the shape of chevron pattern showing the upward direction the organism tunneled through in responds to sudden, episodic, or high sedimentation events.

4) Planolites montanous isp. Erected by Nicholson [38]. Burrows are horizontal to sub-horizontal, unlined, un-branched, and small diameter $\sim 2 \mathrm{~mm}$. The shape of the burrow is sinuous, to tortuous, and circular to elliptical in cross-section. Burrow filled are structureless, and differ from the host rock/sediment. Walls are mostly smooth.

5) Skolithos linearis. Erected by Haldeman [39]. Burrows are straight, cylindrical to curved, distinctly smoothed walled, rarely branched, and vertical to steeply inclined. Unornamented simple shafts are mostly retrusive and merge upward at various angles with bedding planes.

6) Thalassinoides suevicus. Erected by Reith [40]. Burrow system is pre-dominantly horizontal and regularly branched. They form bedding-parallel mazes. Branches ramify at acute angles. The Y-shaped dichotomous bifurcations dominate T-shaped branches. The branches are cylindrical in shape and circular to oval shape in transverse section.

7) Teichichnus rectus. Erected by Seilacher [41]. Vertical and unbranched spreite consist of tightly packed, straight to broadly U-shaped laminae. Burrows have variable dimensions. Longitudinal sections show nested burrows of simple, long, straight to sinous, upward migrated, horizontal to sub-horizontal tunnels. These tunnels are mostly retrusive and merge upward at various angles with bedding planes.

8) Phycosiphon. Erected by Von Fisher-Ooster [42]. The structure is irregularly meandering, black-colored burrows with a pale holo of coarse silt. In cross-section, the burrows are elliptical to sub-circular, U-shaped in the longitudinal profile. Burrow structure is normally erratic, vermicularly tanged. In core, it commonly appears as tiny dark pin-head sized spots. In longitudinal cross-section, it shows discontinuous and surrounded by a pale silt halo.

9) Palaeophycus. Erected by Hall [43]. The structure is straight, slightly curved, slightly undulose or flexuous, smooth or ornamented, typically lined, essentially cylindrical, predominantly horizontal structures interpreted as open burrows; burrow-fill typically massive, similar to host rock, although substantial fill may be absent; where present, bifurcation is not systematic, nor does it result in swelling at the sites of branching. The structures is characterized as passively filled, typically lined, burrows [44].

10) Zoophycos. Erected by Massalongo [45]. Burrow is a circular to lobate sheet-like spreite; either flat, curved, inclined or wound in screw fashion around a central vertical axis. The spreite is a horizontal or sub-horizontal web of closely juxtaposed parallel burrow tunnels. Burrow tunnels system show the path of feeding apparatus during a single probing of the sediment. Successive probing side-by-side in the same direction or plane produces a horizontal spreite. 
Table 2. Summary of the lithology, sedimentary features, description of facies associations (F-1 through F-5) and interpretation of depositional environments.

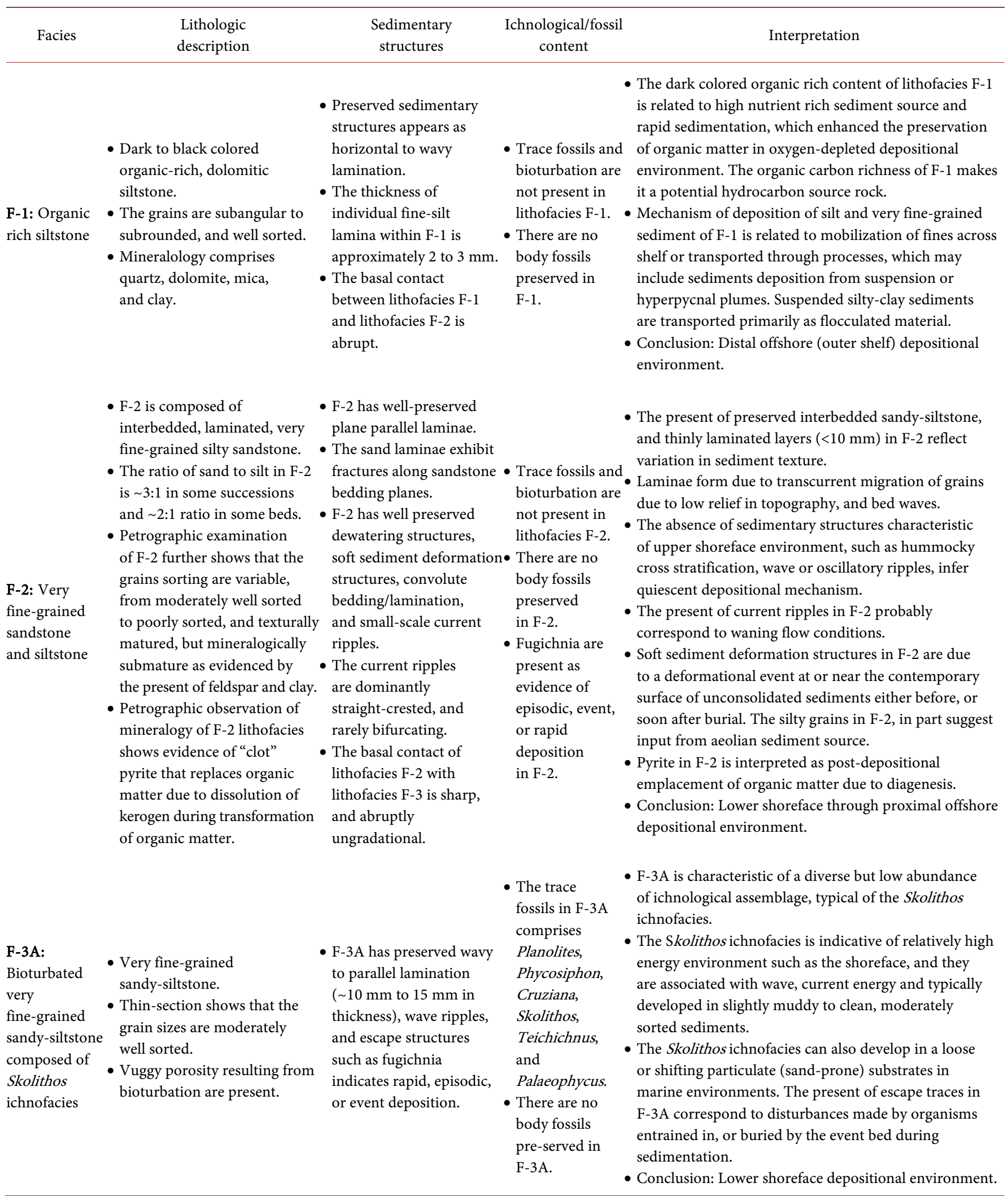


F-3B:

Bioturbated $-\mathrm{F}-3 \mathrm{~B}$ is composed of siltstone

siltstone

composed

of Cruziana

ichnofacies.

\section{dominated by Cruziana $\quad$ No sedimentary \\ ichnofacies. \\ structures.}

- F-3B is moderately well sorted.

Teichichnus, and

Palaeophycos.

In cores, these

traces are not

well preserved.

- F-3B fugichnia-

escape structures

are present.

- F-4 consist of dolomitic, thin beds ( $\leq 1$ meter) of very

F-4:

Dolomitic

very

fine-grained

sandstone

fine-grained sandstone.

- Thin-section petrography confirms that F-4 is quartz rich, moderately well sorted and dolomitic.
- F-4 succession shows a coarsening upward trend.

- Dark grey to black colored, organic rich, pyritized, massive siltstone.

- Petrographic examination of F-5 confirms that the grains are sub-angular to

F-5: Massive sub-rounded.

siltstone. - The texture of pyrite in F-5 under reflected light microscopy appears as irregularly rounded "clots" that partly coalesce with one another and partly separated by non-reflective dolomite.
- Trace fossils such as Planolites, Thalassinoides, Cruziana, and Palaeophycus are ichnocoenosis of the Cruziana ichnofacies.

- The Cruziana ichnofacies is commonly characterized by a high diversity of trace fossils associated with a variety of ichnofauna.

- The present of these trace fossils in F-3B are indicative of distal offshore setting.

- Conclusion: Distal offshore depositional environment.
- The basal contact of F-4 with lithofacies F-5 is sharp and grades into coarse siltstone grade.

- No sedimentary structures.
- Trace fossils and bioturbation are not present in lithofacies F-4.

- There are no body fossils preserved in F-4.
- The coarsening-upward trend in lithofacies F-4 is interpreted as basinward shoreline shift, which often characterizes a progradational trend.

- The coarsening upward succession of F-4 is likely to have accumulated in deepening water, particularly in areas that are not adjacent to the shoreline and are characteristic of facies that prograded basinward during a falling stage of regression.

- Conclusion: Proximal offshore depositional environment.

- The dark grey to black colored, organic carbon content of F-5 is a result of high nutrient rich sediment source and rapid sedimentation, which enhanced the preservation of organic matter.

- No sedimentary structures.

- The upper contact of F-5 with the overlying Doig Formation is reminiscent of erosional lag deposit characterized by a Glossifungites-Trypanites surface.

\footnotetext{
- Trace fossils - The composition of detrital dolomite in F-5 is and bioturbation interpreted as post-depositional in origin, rather than are not present in-situ.

in lithofacies - Pyrite in F-5 is related to post-depositional emplacement F-5.

- There are no body fossils pre-served in F-5.
}

based on consideration of facies associations, ichnological criteria and depositional characteristics. Detailed description and interpretation of the facies are discussed below following the classification scheme and analyses of [46].

\subsubsection{Lithofacies F-1 Description: Organic Rich Siltstone}

Lithofacies association F-1 is a dark to black colored organic-rich, dolomitic siltstone. 
The grain-size is primarily composed of coarse-silt with thin laminae of fine-silt. The fine-silt laminae are preserved as horizontal to wavy lamination (Figure 11(A)). The thickness of individual fine-silt lamina within Lithofacies F-1 is approximately $2 \mathrm{~mm}$ to $3 \mathrm{~mm}$. Thin-section petrography of samples obtained from Lithofacies association F-1 confirm the nature of silt composition and further show that the grains are subangualar to subrounded (Figure 11(D)), and well sorted (Figures 11(E)-(G)). SEM analysis shows that the organic rich siltstone of Lithofacies F-1 is composed of dolomite, mica, and clay minerals (Figure 11(B) and Figure 11(C)). Trace fossils are not present in Lithofacies F-1. The basal contact between Lithofacies F-1 and Lithofacies F-2 is abrupt.

\subsubsection{F-1 Interpretation}

The dark color organic rich content ( $2 \mathrm{wt} \%$ TOC) of Lithofacies F-1 is related to high nutrient rich sediment source and rapid sedimentation, which enhanced the preservation of organic matter [47] in oxygen-poor depositional environment [47]-[55], where density or temperature stratified water column form, typically below wave-base [47]. Oxygen poor environments can be characteristic of a distal offshore setting [51] [53] [54]. The organic matter and high TOC of Lithofacies F-1 is associated with the clay mineral. [56] study the relationship between organic matter and shale in modern sediments and found that adsorption of carbon compounds onto clay mineral surfaces played a fundamental role in the burial and preservation of total organic carbon in the sediment. Organic matter is an economically important source of hydrocarbons, minerals, and metals [56]. Organic carbon is derived mostly from photosynthesis by plants and algae, which are atoms of carbon buried in sediments [57]. Lithofacies F-1 is mainly composed of coarse silt-sized grains. Silt and very fine-grained sediment is the product of weathering, and subsequently transported by fluvial or aeolian mechanisms. [58] used depositional model (Figure 12) to show sediment source and various ways of sediments transport to environment of deposition. Particularly, [58] shows that the deposition of silt and very fine-grained sediments are related to mobilization of fines across-shelf, or transported through processes, which may include sediments deposition from hyperpycnal plumes [59] [60]. As hyperpycnal flow gradually loses part of its suspended load progressively seaward, the finer-grained silt-sized particles are deposited in distal offshore environments [61], where changes in bottom water anoxia and sediments settling from suspension mostly dominate [62].

Preserved horizontal to wavy lamination in lithofacies F-1 developed during sedimentation when finer-grains settle from suspension under gravity influence in a decelerating flow regime as experimented by [63]. The outershelf (distal offshore setting) environment is a locus for such decelerated bottom flow regime [64]. The sluggish flow regime enhances the development of lamination, characterized by very distinct, abrupt laminae surfaces of less than $1 \mathrm{~mm}$ thick, which contains finer-grained particles than the surrounding deposit [65]. The absence of soft-sediment deformation structures and convolute bedding in Lithofacies F-1 imply that wave loading, episodic, or seismically triggered deposition were not at play in the depositional process of Lithofacies F-1. 

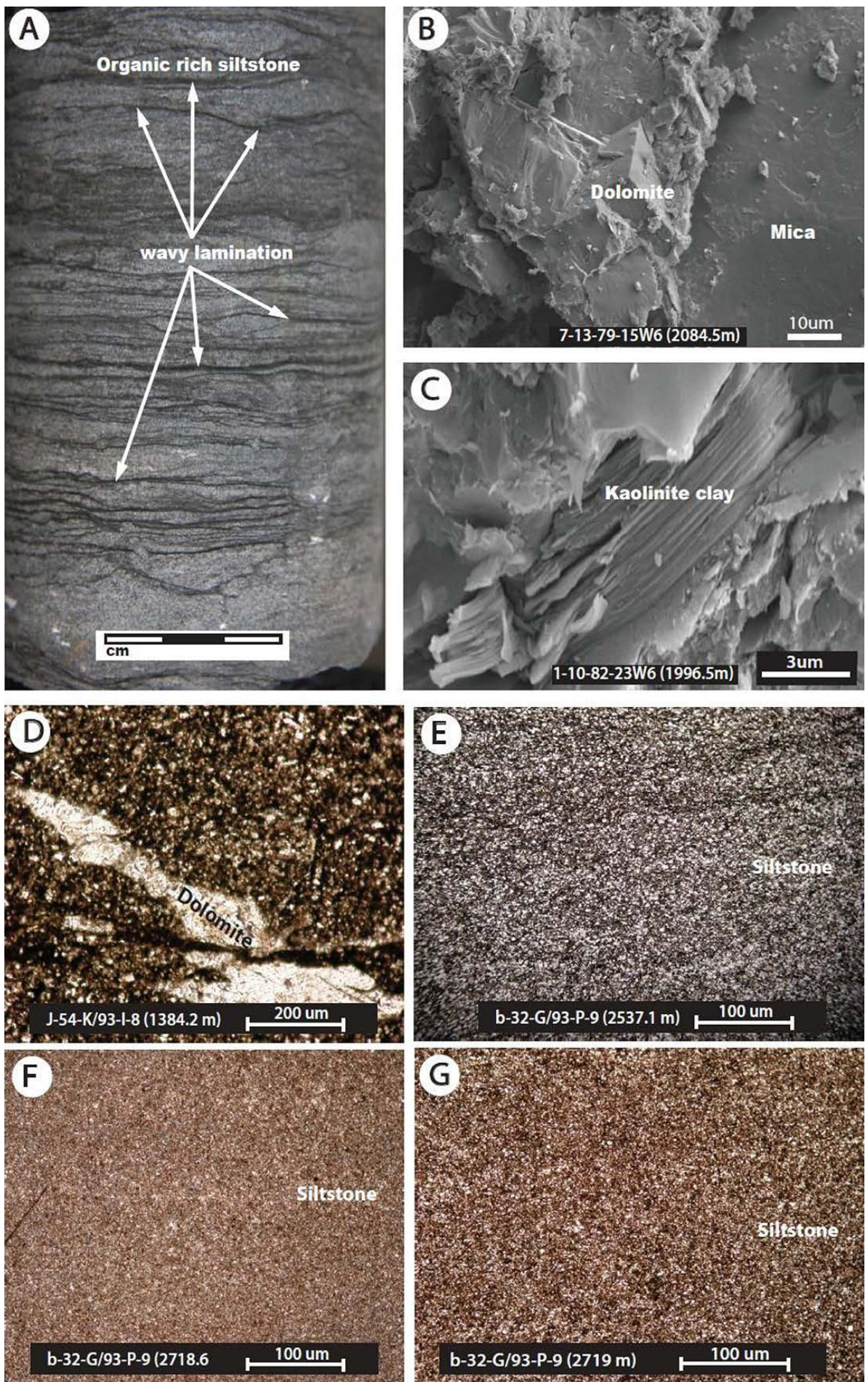

Figure 11. Shows core photo, scanning electron microscopy (SEM) images and petrographic microphotographs of Lithofacies association (F-1) from the Montney Formation. (A) Core photo of Lithofacies F-1, organic rich siltstone with wavy laminae (Well: 1-10-82-23-W6, depth 1996 m), Monias gas field, northeastern British Columbia; (B) shows the mineralogy of Lithofacies association F-1 composed of dolomite and mica (Well: 7-13-79-15W6, depth $2084 \mathrm{~m}$ ); (C) shows clay mineral associated with the organic component of Lithofacies association F-1, with distinctive layering characteristic of kaolinite clay (Well: 7-13-79-15W6, depth 2084); (D) detrital dolomite admixed quartz-grained siltstone (Well: J-54-K/93-I-8, depth $1384.2 \mathrm{~m}$ ); ((E) through (G)) shows very fine-grained, well sorted siltstone of Lithofacies association F-1 (Well: b-32-G/93-P-9). 
The subangular to subrounded grains of Lithofacies F-1 have implications for the sediment source, transport mechanism and duration of entrainment [66] [67]. Generally, grain roundness is a fundamental physical property of sediment particles, affecting their entrainment, transport, deposition, and, therefore provides clues about the sediment provenance, transport history and depositional conditions [68] [69]. Subangular to subrounded grainsizes of Lithofacies F-1 infers relatively short distance of transport from sediment source-rock prior to initial entrainment into suspension [70] [71]. The well sorted textural characteristics of Lithofacies F-1 implies the evenness of the mass of particles with the total amount of material that are within the same grain-size distribution as seen under microscopy. Mineralogical composition of Lithofacies F-1 includes silt-sized quartz, dolomite, mica, and clay. The silt size grains in Lithofacies F-1 derived its origin from the mechanical and chemical breakdown of quartz [72] [73] [74] [75] [76]. In support of weathering as a mechanism of disintegration of quartz into silt sized particles, an account of structural defects in quartz crystals was experimentally presented by [75] [76], and their findings suggest that silts may be released directly from bedrock during weathering [75] [76]. Furthermore, production of silt is associated with fracturing of coarser quartz grains during weathering and pedogenesis [77]. The depositions of silty sediments into distal setting are significantly related to flocculation of fines due to the affinity of mica as a major component of siliciclastic sediments [27]. Suspended sediments are well known to be transported primarily as flocculated material [78]. Flocs are composed of a complex matrix of organic particles, inorganic particles (e.g. clays and silts) and substantial interfloc spaces (pores) that allows for the retention, sustenance and flow through water [78].

The profound plume experimental work of [57] shows bedload transport of mud by floccule. In [57] [78] [79] show that floccule is associated with bedload transport in a thin layer of floccule-carrying clay in suspension within boundary-layer of higher concentration and interpreted the phenomenon as a direct analogue to the heavy fluid layer in sand transport. As a result of flocculation, significant alterations of the constituent particles in a hydrodynamic flow modifies grain-size and their shape, thereby enhancing effective transport of sediment [78].

Thin-section petrography shows that the dolomite in Lithifacies F-1 is detrital. The detrital nature of the dolomite in some thin-sections show sigmoidal morphorlogy resembling ripple lamination, suggesting that the dolomite fragments may have been shed from carbonate apron as debris. The scattered, detrital dolomite nature seen in thin-section petrography could be interpreted as postdepositional in origin, rather than in-situ.

The absence of bioturbation in Lithofacies F-1 imply stressed and disaerobic conditions [54] [58] [80] [81]. Thus, Lithofacies F-1 deposition may be related to pelagic processes [82]. Pelagic depositional process is supported by the absence of depositional features characteristic of shoreface, such as storm or wave generated primary sedimentary structures (cross bedding, or hummocky cross stratification). The absence of trace fossils in lithofacies F-1 may be due to dysaerobic or oxygenation stress [34] [54] [82] 
[83].

Dysoxic conditions prevailed for most of the Permian-Triassic (P-T) boundary that caused mass extinction, which ravaged biotic communities, the most severe in Earth's history [15] [84]-[97], due to unequalled decline in the amount of dissolved oxygen in the world's oceans [75]-[88]. The anoxic conditions extended intermittently into shallow marine (proximal shelf) depositional settings [4] [51] [89], which have been reported to be associated with global anoxic conditions that subsequently caused a prolonged faunal recovery in the aftermath of Permian-Triassic biota crises [85] [90]. The protracted fauna recovery continued into the Lower and Middle Triassic time [4], thereby delaying fauna revitalization for several millions of years following the fauna mass extinction [51] [91]-[96]. The harsh environmental conditions post P-T fauna environmental crises may have implications for the non-fossiliferous, or the non-evidence of fauna traces in Lithofacies association F-1. Based on the above sedimentological characteristics of Lithofacies association F-1 (organic rich siltstone), it is interpreted herein as a deposition in a distal offshore (outershelf) to ramp setting (Figure 12). A shelfal environment has been interpreted for similar siltstone facies [64] [98], or outershelf to continental slope bathymetry [64] [98]. This interpretation is in line with previously reported depositional environment for the Lower Triassic Montney Formation by [4] [9] [23] [98] [99].

\subsubsection{Lithofacies F-1 Description: Very Fine-Grained Sandstone and Siltstone}

Lithofacies association F-2 is composed of interbedded, laminated, very fine-grained sandstone and siltstone (Figure 13(A), Figure 14, and Figure 15(C)). The ratio of sand to silt in Lithofacies F-2 is approximately 3:1 (Figure 15(C)) in some successions, and $\sim$ 2:1 ratio in some beds (Figure 13(B), Figure 13(C), and Figure 13(D)). Thin-section analysis of Lithofacies association F-2 confirms that the lithology is siliceous, and the grain-size ranges from very fine-grained sandstone to coarse siltstone grade (Figure 17(D)). Petrographic examination of Lithofacies F-2 further shows that the grains

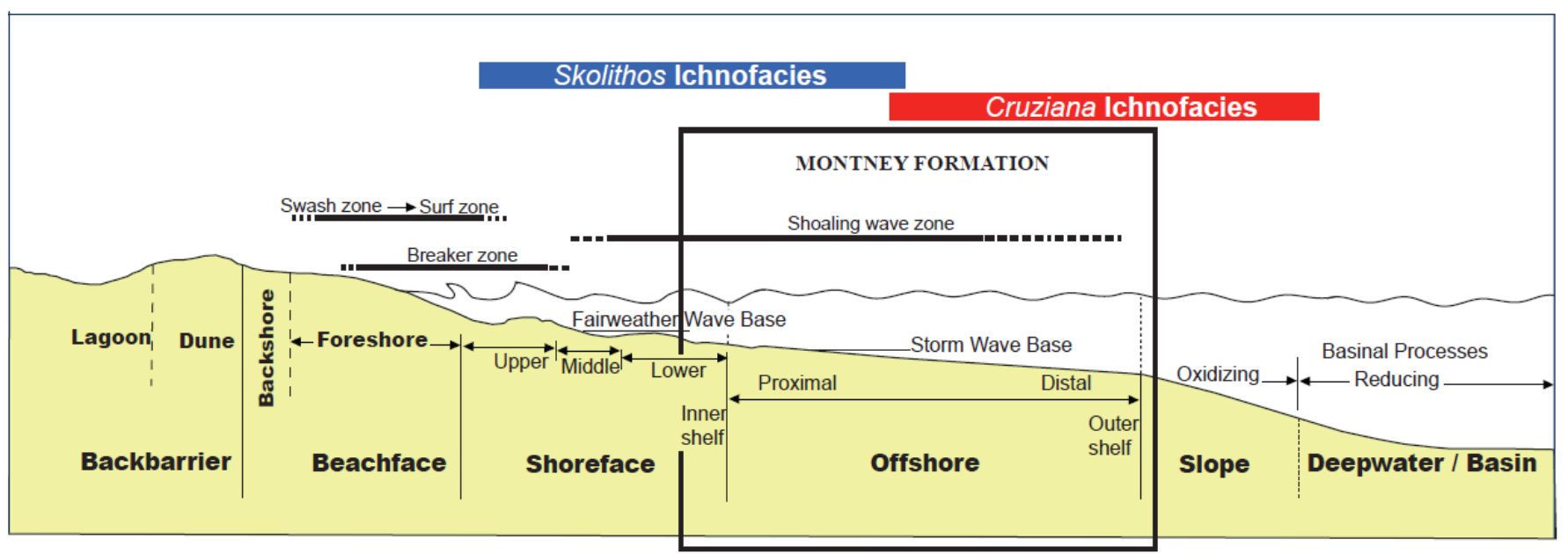

Figure 12. Schematic representation of the relationship between processes affecting transport and deposition of fine-grained sediments into distal offshore and deep-water environments. 

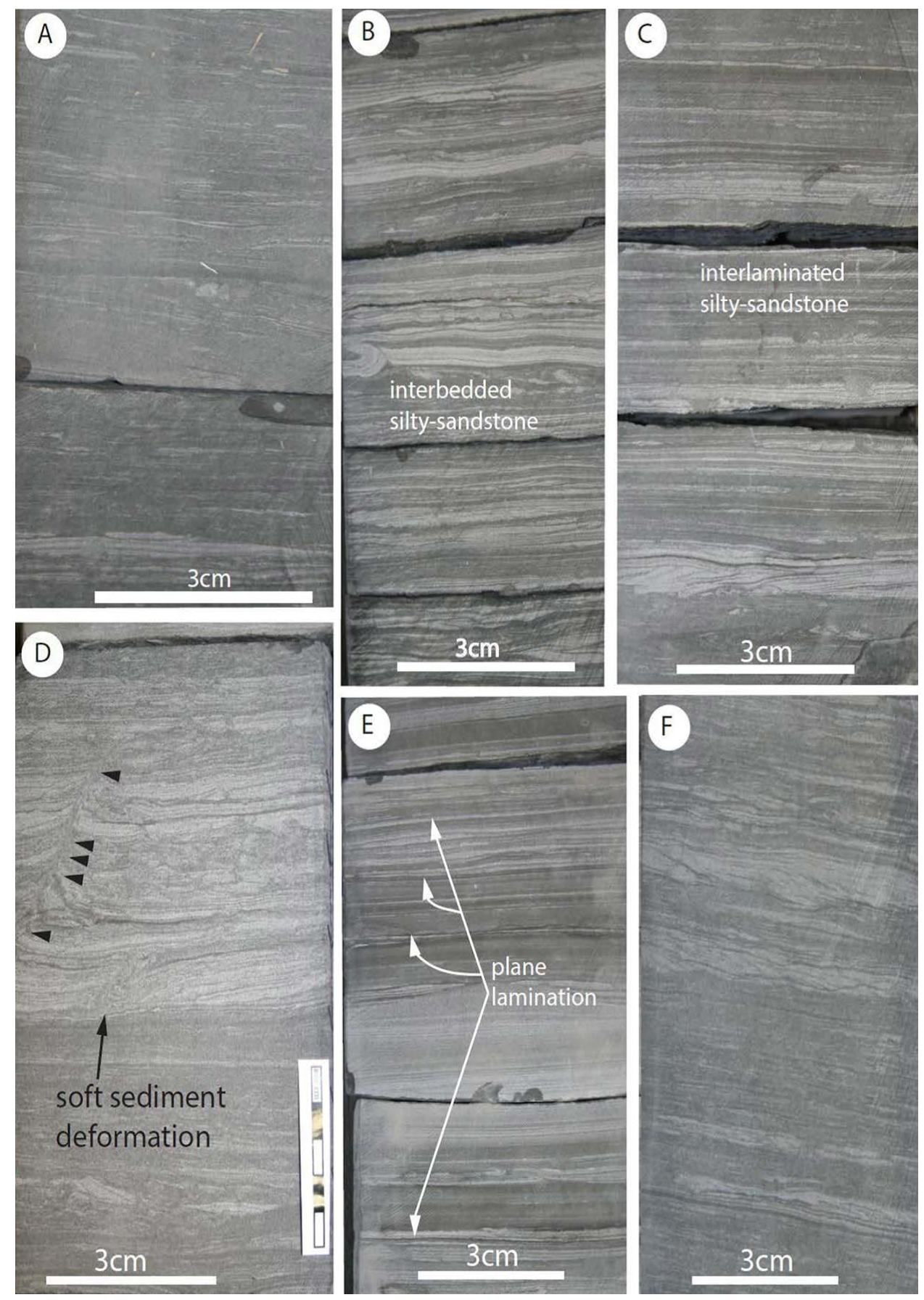

Figure 13. Core photographs showing depositional characteristics of Lithofacies F-2. (A) Shows interbedded sandy siltstone (well: 9-29-79-14W6; depth: $1970 \mathrm{~m}$ ). The percentage of sand proportion decreases upward from base of A to top of A; (B) laminated siltstone interbedded with very fine-grained sandstone (well: 11-04-79-14W6; depth: $2052.5 \mathrm{~m}$ ); (C) shows interlaminated silty-sandstone with fracture along sandstone bedding plane (well: 11-04-79-14W6; depth: 2051 $\mathrm{m})$; (D) very fine-grained sandstone with soft sediment deformation structure overlying coarsegrained siltstone (well: 11-04-79-14W6; depth: $2053.4 \mathrm{~m}$ ); (E) plane laminated silty-sandstone. Interbedded silty-sandstone (well: 11-04-79-14W6; depth: $2055 \mathrm{~m}$ ); (F) the proportion of sand increases towards the top of Plate-F (well: 9-29-79-14W6; depth: 1973.5 m). 
sorting are variable, from moderately well sorted to poorly sorted (Figure 17), and texturally matured, but mineralogically submature as evidenced by the present of feldspar and clay (Figure 17(D)). In addition, thin-section petrography shows that the mineral composition of Lithofacies F-2 comprises quartz, mica, pyrite, and detrital dolomite (Figure 17). SEM analysis further shows that some of the quartz in lithofacies F-2 has developed authigenic quartz overgrowth (Figure 16(G)).

Lithofacies F-2 have well-preserved plane parallel laminae (Figure 13, Figure 14, Figure 18, and Figure 19). The sand laminae exhibit fractures along sandstone bedding planes (Figure 15(B)). Depositional features in Lithofacies F-2 comprise dewatering sedimentary structures, soft sediment deformation structures, convolute bedding/ lamination (Figure 14(C); Figure 18(C)), and small-scale current ripples (Figure 15(A), Figure 19). The current ripples are dominantly straight-crested, and rarely bifurcating (Figure 16(A), Figure 16(D)). Body fossils are not present in Lithofacies F-2. The basal contact of Lithofacies F-2 with Lithofacies F-3 is sharp, and abruptly ungradational.

\subsubsection{F-2 Interpretation}

Lithofacies association F-2 is composed of interbedded, laminated, and very finegrained sandy-siltstone. [100] originally defined laminae (Figure 14(A) and Figure 15(A)) as sedimentary strata that are less than $10 \mathrm{~mm}$ thick. The present of preserved interbedded sandy-siltstone, and thinly laminated layers (approximately $<10 \mathrm{~mm}$ ) in Lithofacies association F-2 reflect variation in sediment texture between grain-size during sedimentation. The formation of laminae involves transcurrent migration of grains due to low relief in topography, and bed waves [101] [102]. Low relief and bed waves migration of sediments are characteristic of the lower shoreface through proximal offshore environment [103] [104]. Thinly laminated silt and very fine-grained sand in lithofacies F-2 may be related to deposition resulting from gravity influenced sedimentation in lower shoreface environment, where fair weather processes are dominant.

Silt and very fine-grained textural characteristics of Lithofacies F-2 suggests that the sediments may have been initially deposited on the shelf as fine-grained sediments, and subsequently transported either via suspension or near-bed migration to lower shoreface-proximal offshore settings [103]. This interpretation is supported by the absence of sedimentary structures characteristic of upper shoreface environment, where higher energy dominate [104], such as hummocky cross stratification, wave or oscillatory ripples, which are primarily a response to high-energy currents and waves [105]. Thus, quiescent sedimentation processes may have dominated during the deposition of very fine-grained sandstone interbedded with siltstone of Lithofacies F-2. Silt and very fine-grained sand in Lithofacies F-2, in part suggest the possibility of input from aeolian sediment source. Evidence supporting aridity in Western Canada Sedimentary Basin (WCSB) during the Triassic time was reported by [24] in the study of paleogeographic, paleolatitude and paleomagnetic analyses. Fauna record [12] and paleolatitude study shows that paleoclimate may have ranged from sub-tropical to temperate [11] [12] [24] during the Triassic period of WCSB, and has been interpreted to be arid, and 

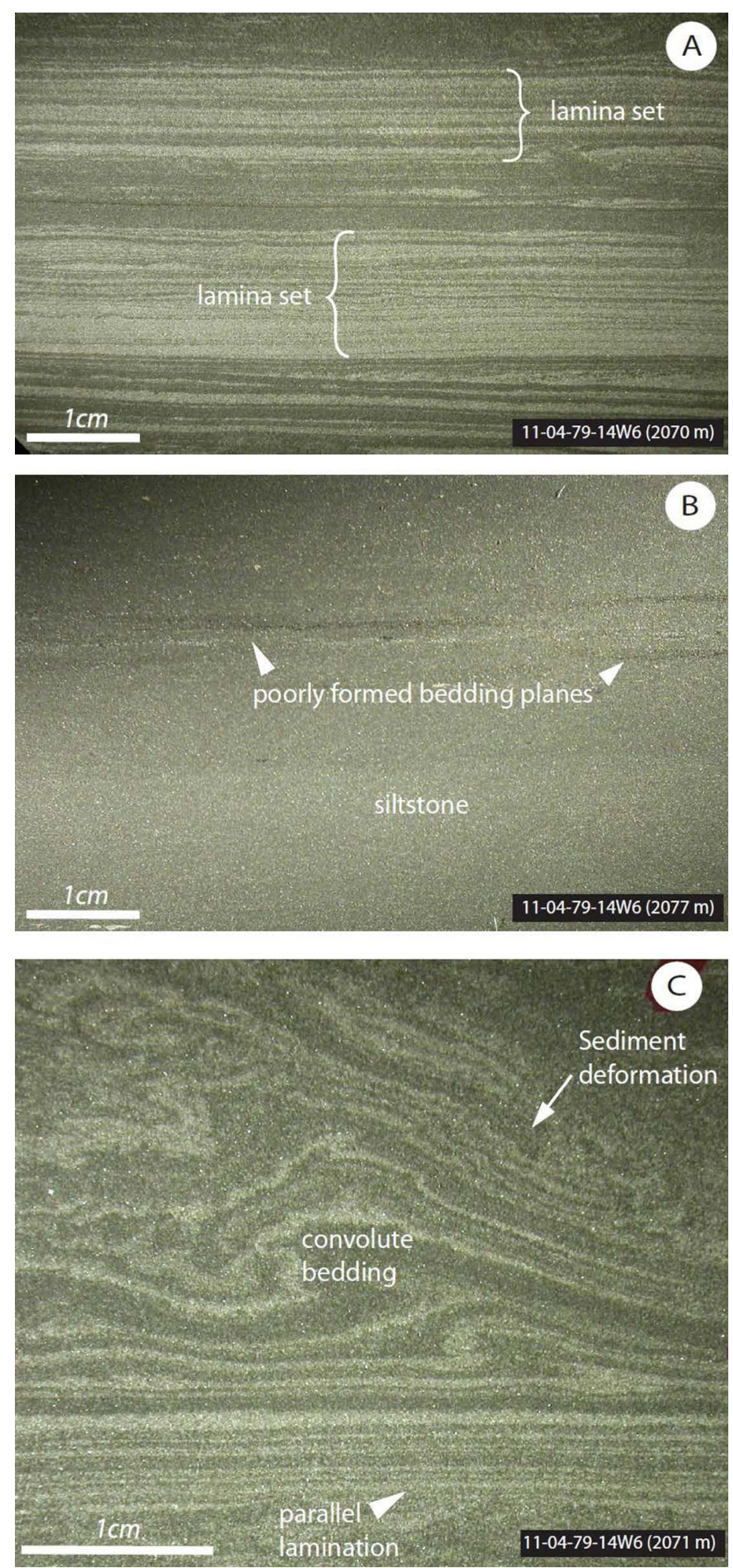

Figure 14. Microphotograph of core samples showing sedimentary structures in Lithofacies association F-2. (A) Laminated, very fine-grained silty-sandstone (well: 11-04-79-14W6; depth: $2070 \mathrm{~m}$ ); (B) coarse-grained siltstone and very fine-grained sandstone with poorly formed bedding planes (well: 11-04-79-14W6; depth: $2077 \mathrm{~m}$ ); (C) shows soft sediment deformation structure (well: 11-04-79-14W6; depth: $2071 \mathrm{~m}$ ). 

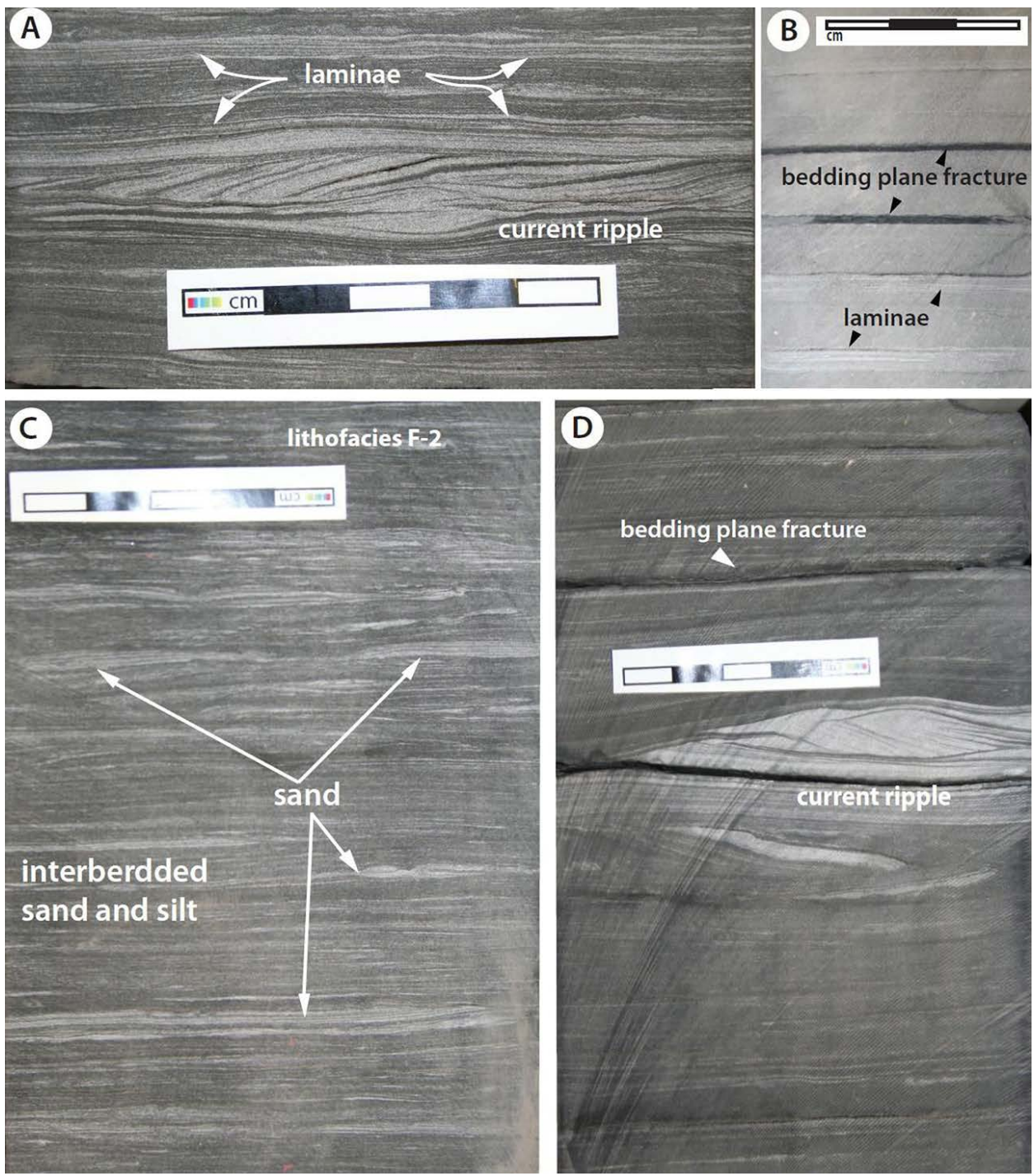

Figure 15. Core photographs showing depositional characteristics of Lithofacies F-2. (A) Laminated very fine-grained, silty-sandstone with current ripple (well: d-39-F/93-P-9; depth: 2655.5 $\mathrm{m}$ ); (B) siltstone with fractured along bedding planes (well: 8-22-82-20W; depth: $1818.7 \mathrm{~m}$ ); (C) shows interbedded silty-sandstone and very fine-grained sandstone (well: 9-29-79-14W6; depth: $1946.9 \mathrm{~m}$ ); (D) shows siltstone, current ripple and bedding plane fracture (well: 11-04-79-14W6; depth: $2076.2 \mathrm{~m})$.

was dominated by winds from the west [24] [106]. Paleoclimate of $30^{\circ} \mathrm{N}$ as the location of the WCSB in Triassic time is consistent with arid climate and desert conditions, in which aeolian depositional processes can thrive. Evidence that supported seasonal aridity during the Triassic was established by [106] through the measurement of paleocurrent on aeolian sandstone beds, which indicated a wind flow direction from northeast in a southwest direction. The southwest directional wind transport of sediments is believed to have released seasonal offshore silt and very fine-grained sands into marine surface water [23]. The north to south longshore sediment transport affected Montney sedimentation [23]. 

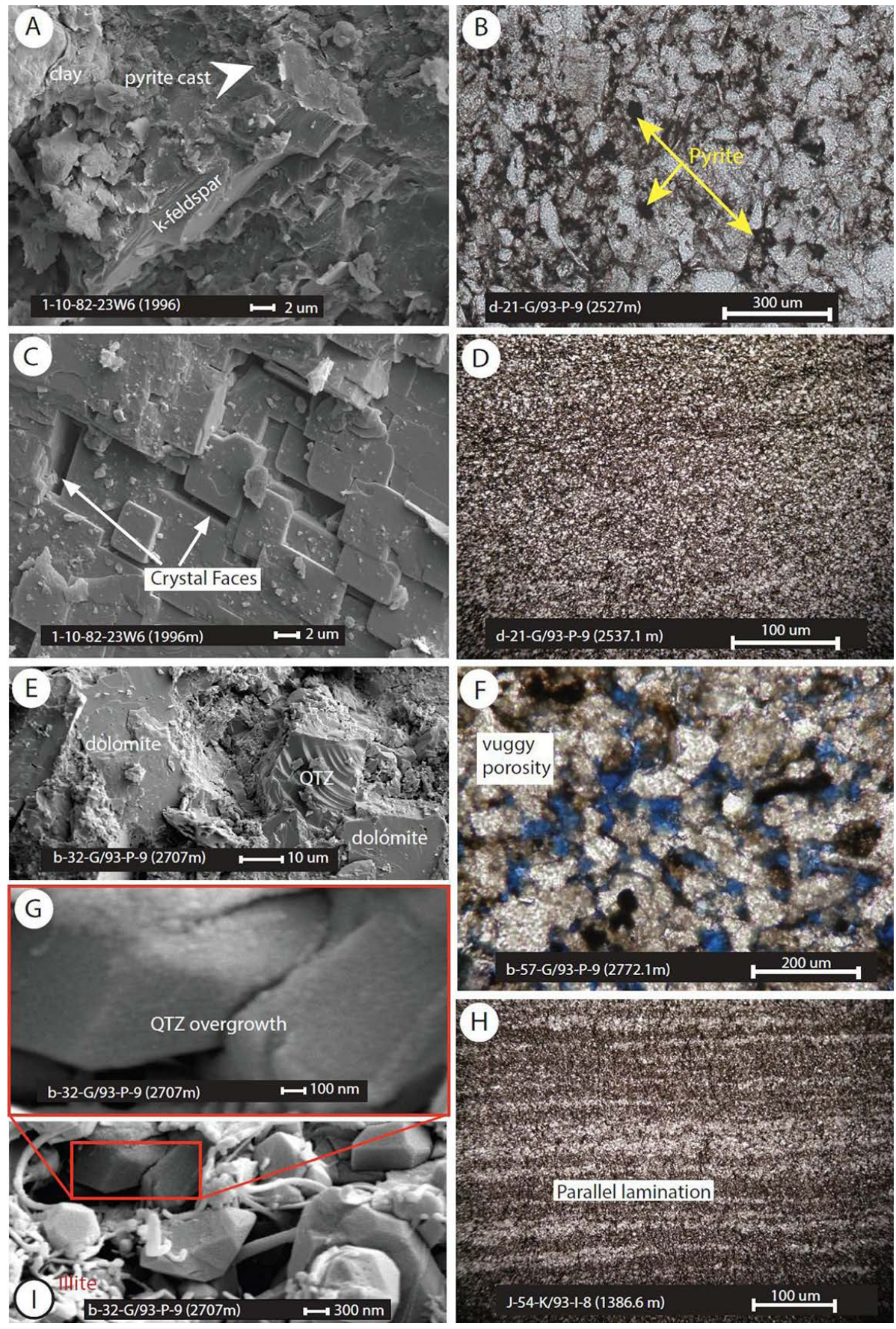

Figure 16. Microphotographs analyzed using scanning electron microscopy (SEM) and thin-section petrography. (A) Shows potassium feldspar, calcium reach feldspar, pyrite cast (white arrow), which forms as a result of diagenesis (well: 1-10-82-23W6; depth: $1996 \mathrm{~m}$ ); (B) pyritic dolomitic sandstone, sub-rounded grains, and moderately poorly sorted (well: d-21-G/93-P-9, depth: $2527 \mathrm{~m}$ ); (C) shows dolomite with perfect cleavage. The crystal faces exemplified brittleness of lithology due to tensile stress (well: 1-10-82-23-W6, depth: $1996 \mathrm{~m}$, Monias field); (D) very fine-grained sandstone and siltstone (well: d-21-G/93-P-9, depth: $2537 \mathrm{~m}$ ); (E) a mixture of massive, fractured dolomite and quartz exhibiting conchoidal fracture; (F) shows vuggy porosity associated with intergranular and grained moldic, formed by partial leaching to complete dissolution of feldspar grains and other unstable minerals (well: b-57-G/93-P-9; depth: 2707 m); (G) shows authigenic quartz overgrowth due to diagenesis (well: b-57-G/93-P-9; depth: $2707 \mathrm{~m}$ ); (H) shows parallel, interlaminated, interstratified very fine-grained sandy-siltstone and argillaceous siltstone due to grain size difference (well: J-54-K/93-I-8; depth: $1386.6 \mathrm{~m}$ ); (I) shows quartz overgrowth (insect for Plate G), illite clay and micro void spaces (inter-particle porosity) (well: b-57-G/93-P-9; depth: 2707 m). 

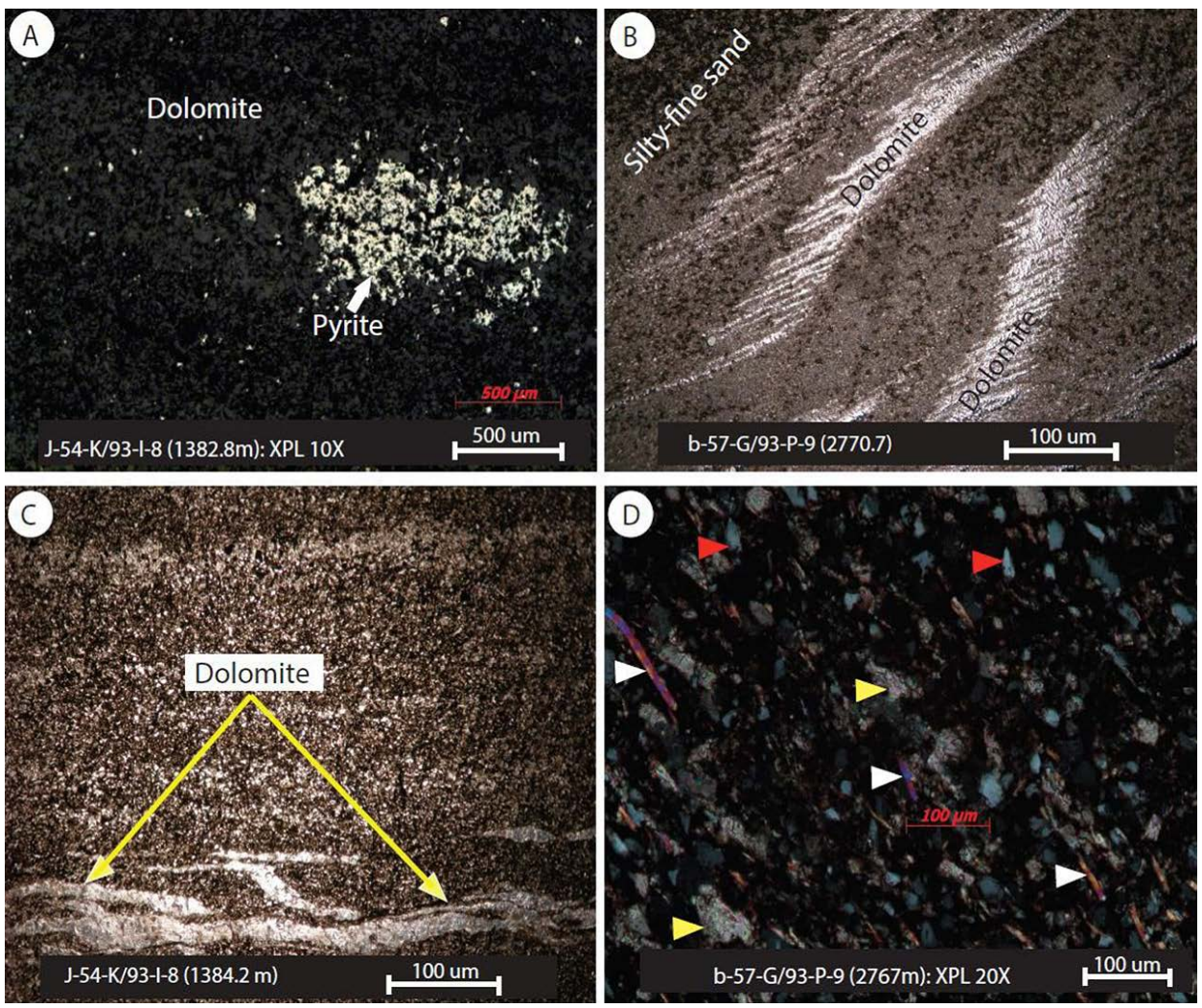

Figure 17. Photomicrographs in thin-sections showing mineralogy for lithofacies F-2. (A) Crossed polarized light showing pyrite mineral admixed dolomite mineral, quartz, mica and detrital grains. Pyrite is an indication of diagenesis in the Montney Formation; (B) dolomitic silty-sandstone. The detrital dolomite forms ripple; (C) detrital dolomite admixed silty-sandstone; (D) shows mica, quartz, dolomite, and detrital grains. In Plate D, red arrow = Quartz; yellow arrow $=$ Dolomite; white arrow $=$ Mica.

The siliceous characteristics of Lithofacies F-2 imply quartz dominant amongst the sandstone mineralogical composition. The variable grain sorting (moderately well sorted to poorly sorted) of Lithofacies F-2 is related to the interbedded sandy-siltstone (Figure 17(A) and Figure 17(D)), and is interpreted as texturally matured, but mineralogically submature. The sedimentological manifest of small-scale current ripples (Figure 15(A), Figure 15(D); Figure 18(A)) form a continuum of Lithofacies F-2 interpretation. Current ripple probably correspond to waning flow conditions [107]. Current ripples readily form in shallow water, but can also form in deepwater setting due to ocean-bottom currents [108]. However, the current ripple reported in Lithofacies F-2 may have formed in lower shoreface or proximal offshore environment. The proximal offshore setting has relatively low topographic gradient, which provides an excellent platform for the formation of ripples under deceleration of currents, as sand and silt fall from suspension during low energy coupled with dominance of sand that are reworked on the beds into ripples [108]. Deformation structures in Lithofacies F-2 (Figure 13(D); Figure 14(C); Figure 18(C); Figure 19(A)) is a result of wave loading commonly due to storm or high-energy deposit [109]. Soft sediment deformation 

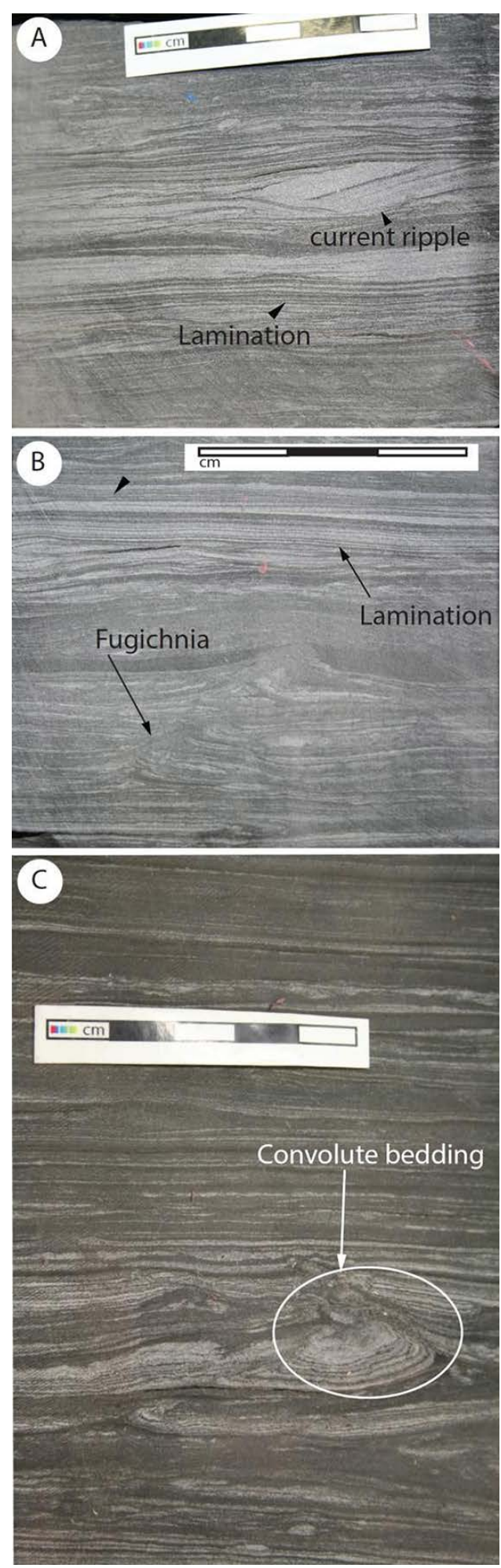

Figure 18. Core photographs showing depositional characteristics of Lithofacies F-2. (A) Shows lamination and current ripple (well: d-39-F/93-P-9; depth: $2660.6 \mathrm{~m}$ ); (B) shows sediment deformation structure and parallel lamination of very fine-grained silty-sandstone (well: d-39-F/ 93-P-9; depth: $2659.8 \mathrm{~m}$ ); (C) shows convolute bedding/sediment deformation (well: d-21-G/ 93-P-9; depth: $2526.5 \mathrm{~m}$ ). 

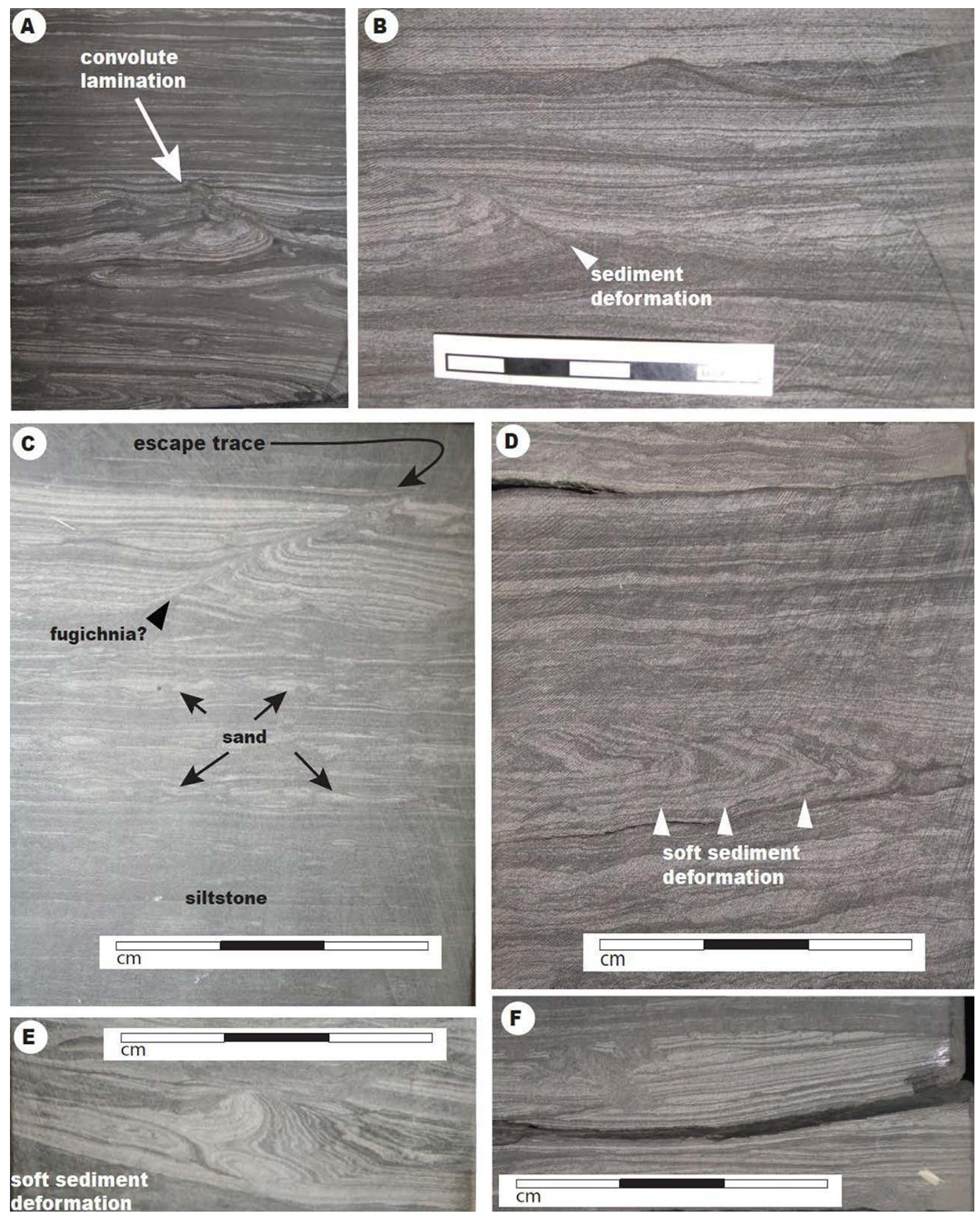

Figure 19. Core photographs showing various types of sediment deformation in Lithofacies F-2. (A) Shows convolute lamination/bedding (well: d-21-G/93-P-9; depth: $2526.5 \mathrm{~m}$ ); (B) shows micro-fault that resulted in discontinuity of parallel lamination due to sediment deformation (well: d-21-G/93-P-9; depth: $2540.5 \mathrm{~m}$ ); (C) shows fugichnia resulting from sediment deformation caused by escape trace during high or episodic sedimentation (well: 9-29-79-14W6; depth: $1985.2 \mathrm{~m}$ ); (D) shows soft sediment deformation structure caused by sediment loading and dewatering (well: d-21-G/93-P-9; depth: $2541 \mathrm{~m}$ ); (E) shows soft sediment deformation/convolute lamination (well: 9-29-79-14W6; depth: 1965.5 m); (F) shows lamination and sediment deformation (well: 11-04-79-14W6; depth: 2097 m). 
structures in Lithofacies F-2 are formed due to processes occurring during a deformational event at or near the contemporary surface of unconsolidated sediments either before, or soon after burial [110]. Deformation structure are produced due to mechanical forces causing plasticity, commonly related to gravity acting upon weak sediment, usually silts or sands, prior to or soon after, or at deposition along the sediment surface [110]. Soft sediment deformation structures can develop only in the presence of susceptible sediments, with appropriate forces that can trigger deformation mechanism [111] [112]. Liquefaction or fluidization is the most important agent for the development of sediment deformation structures in water-saturated and cohesionless sediments [111]. Liquefaction or fluidization in unconsolidated sediments may be triggered by several processes such as seismic shocks, or aftershocks, wave loading or overloading, groundwater movements, and effect of storm waves [113]. The contrasting grain-sizes (very fine-grained sand and silt) of Lithofacies F-2 characterized by alternating grain sizes, overlying homogeneous sediments makes deformation structure possible.

The analysis of soft-sediment deformation structures can unravel the driving force, deformation mechanism, timing of deformation relative to sedimentation, and the triggering agent [113]. Sediment deformation structures in Lithofacies F-2 may be related to the Triassic tectonic activity. [114] [115] [116] [117] interpreted sediments loading, deformed beddings, slumping structures and small-scale faults as indicators of tectonically driven factors that influenced the deposition of Triassic succession. Other workers [117] [118] have interpreted some of the deformation structures in the Montney Formation to be related to initial terrain collision in the British Columbia/Yukon as part of a regional tectonism of Early to Middle Triassic. Other possibilities for the formation of deformation structures in Lithofacies F-2 include seismicity, current turbulence associated with the onset of sediment-laden hypopycnal plumes could trigger deformation of laminae [118] [119] [120], and hydrostatic pressure effects associated with upwelling [121] [122].

Convolute bedding [101], and convolute lamination [123] [124] in Lithofacies F-2 are associated with fluid escape, and their formation is related to grain-size and deformation mechanism. The convolute lamination/bedding structures involve folding of lamination into cuspate upright form with a sharp anticline and a relatively gentle syncline (Figure 14(C)), and they are formed as a result of plastic deformation of partially liquefied sediment usually occurring shortly after deposition [108]. Convolute lamination may also be the product of seismically triggered event that results in rapid deposition. The present of soft sediment deformation and convolute lamination in Lithofacies F-2 (Figure 14(C); Figure 16(C)) are evidence of penecontemporaneous event, or small-scale local episodic deposition.

The observed bedding plane fractures in Lithofacies association F-2 formed as a result of grain-size gradations and internal layering of parallel lamination and depositional fabric [125]. Natural fractures are important features that can help deliver hydrocarbons from tight rock matrix of a formation to the wellbore [126]. The natural 
bedding plane fractures in Lithofacies F-2 have the potential to serve as both initial permeability conduit [9] and can also hydraulically enhanced permeability conduits for hydrocarbon flow from tight rock reservoir [126] [127]. Mineralogical composition of Lithofacies F-2 comprises quartz, dolomite, feldspar, mica, illite clay and pyrite. Quartz is the most abundant mineral in sandstone and serves as an indicator of textural and compositional maturity [68]. Quartz rich sediments have implication for porosity, particularly, effective porosity-the result of interconnectivity of pores in a siliciclastic matrix. Based on SEM analysis, the quartz in Lithofacies F-2 shows evidence of quartz overgrowth (Figure 16(G)). Although quartz overgrowth within a dolomitic fabric insinuates complex relationships between quartz and carbonate, however, textural and mineralogical evidence from SEM (Figure 16(E) and Figure 16(G)) suggests that at least two different phases of cementation may have taken place during authigenic modification of quartz. The dolomitic nature of the Montney Formation siltstone within the study area implies that carbonate cements may have been precipitated subsequent to, or post-dated an early quartz cement, and may have peripherally replaced the cement of overgrowth and detrital grain surfaces [128]. The present of feldspar in Lithofacies F-2 is diagnostic of provenance, and useful in the estimation of paleoclimatotogical conditions [129], which can be derived from unstable minerals, particularly, the present of feldspar group in a siliciclastic deposit [130]. Plagioclase feldspar tends to be unstable during weathering, which limits its use to rocks that were deposited under tectonic conditions and favorable for rapid deposition [129]. The instability of plagioclase feldspar is useful in the interpretation of provenance and sediment history because any sandstone containing appreciable amounts of plagioclase feldspar would probably be first-cycle, and therefore, do not lead to erroneous interpretation on multi-cycle material [129]. Second-cycle feldspar grains are not common, because feldspar is not resistant to weathering. In general, most plagioclase feldspar in sedimentary rocks are sourced from igneous or gneiss [68] [72]. The interpretation for the present of feldspar in Lithofacies F-2 indicate that the sediments are compositionally immature and have not undergone multiple cycles of sedimentation and redeposition.

Pyrite in Lithofacies F-2 (Figure 16(A); Figure 17(A)) is interpreted as post-depositional emplacement due to diagenesis. The pyrite in Lithofacies F-2 (Figure 18(A)) appears as detrital pyrite aggregate within a dolomitic, very fine-grained, siltstone matrix (Figure 16(A); Figure 17(A)). Aggregated pyrite has been defined by [131] [132] as "a texture seen under the microscope, under reflected light microscopy appearing as small pyrite crystals that are aggregated into irregularly rounded 'clots' that are partly coalescent with one another and partly separated by non-reflective clay and carbonate". Aggregate pyrite in Lithofacies F-2 is interpreted to have formed in-situ during diagenesis. Pyrite is an important diagenetic mineral and can help define the diagenetic history of sediments [131]. Thus, the present of pyrite in Lithofacies F-2 is an indication of diagenesis in the Montney Formation.

Detrital dolomite in Lithofacies F-2 appears to have been shed-off from carbonate apron as debris (Figure 17(B)). The present of detrital dolomite has been interpreted 
by [133] as post-depositional in origin. Based on the aforementioned lithological description, petrographic examination, scanning electron microscopy, and depositional characteristics of Lithofacies association F-2, it is interpreted herein as a deposition in the lower shoreface through proximal offshore depositional environment, occurring just below fair-weather wave base (Figure 12).

\subsubsection{Lithofacies F-3 Description}

Lithofacies F-3 is primarily composed of very fine-grained sandstone and coarse siltstone grade. Based on trace fossil assemblage, lithofacies F-3 is subdivided into: Lithofacies F-3A (Skolithos ichnofacies) and lithofacies F-3B (Cruziana ichnofacies). The typical assemblage of the Skolithos ichnofacies and Cruziana ichnofacies is presented as a model in Figure 20. Although the model show ichnofauna diversity and abundance, the recorded trace fossils within the study interval of the Montney Formation in British Columbia does not have abundance and diversity of either the Skolithos ichnofacies, or the Cruziana ichnofacies. The description of lithofacies association F-3A and F-3B are discussed below. The recorded infauna traces in cores from the study area are defined morphologically in Table 1.

\subsubsection{Lithofacies F-3A Description: Skolithos Ichnofacies}

Lithofacies F-3-A is composed of bioturbated, very fine-grained sandy-siltstone (Figure 21). The trace fossils in Lithofacies F-3A comprises Planolites, Phycosiphon, Cruziana, Skolithos, Teichichnus, and Palaephycus. Lithofacies F-3A has preserved wavy to parallel lamination ( $10 \mathrm{~mm}$ to $15 \mathrm{~mm}$ in thickness), wave ripples, sediment deformation, and escape structures such as fugichnia (Figure 22(C), Figure 23). Thin-section analysis of lithofacies F-3A shows Phycosiphon trace fossil (Figure 24(A) and Figure 24(B)), and vuggy porosity resulting from bioturbation (Figure 24(D)). Thin-section examination of Lithofacies F-3A shows that the grain-sizes are moderately well sorted (Figure 24(C)) admix dolomite and pyrite (Figure 24(C), Figure 24(E)).

\subsubsection{F-3A Interpretation}

Lithofacies F-3A comprises trace fossils characteristic of a diverse ichnological assemblage, which is typical of the Skolithos ichnofacies. Such trace fossils suite characterizes fine-grained siltstones and mudstones with diverse suites [134]. The trace fossils within Lithofacies F-3A are Skolithos, Planolites, Phycosiphon, Cruziana, Teichichnus, and Paleaeophycos. The Skolithos ichnofacies is indicative of relatively high-energy environment [134] such as the shoreface. They are associated with wave, current energy and typically developed in slightly muddy to clean, moderately sorted sediments [34]. The Skolithos ichnofacies can also develop in a loose or shifting particulate (sand-prone) substrates in marine environments [34] [134]. The present of escape traces in Lithofacies F-3A correspond to disturbances made by organisms entrained in, or buried by the event bed during sedimentation.

Thin-section analysis shows that the porosity observed in Lithofacies F-3A is associated with biogenic modification or reorganization of sediment fabric due to burrows 


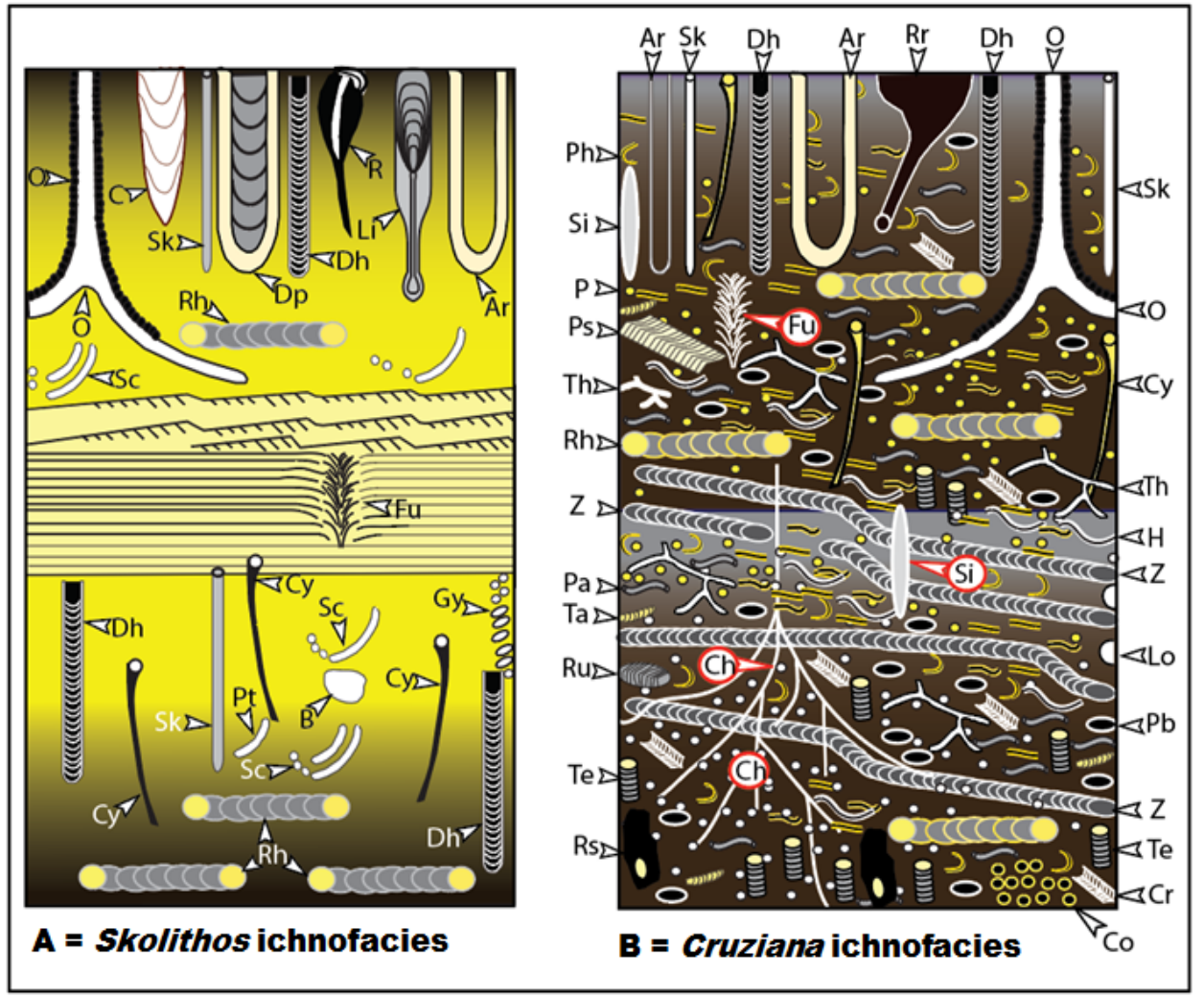

Figure 20. Archetypal expression of the Skolithos ichnofacies and Cruziana ichnofacies; modified from [34]. The diversity and abundances of trace fossils suite represented in this model is farfetched from the reality of the trace fossils observed in the study core interval of the Montney Formation (see Table 1. for trace fossils recorded in the Montney Formation in this study). This model serves the generality of the typical Skolithos ichnofacies and the Cruziana ichnofacies that may exist in any locality. However, a departure from this may occur when dealing with mixed Skolithos and Cruziana ichnofacies, in which cut crossing ichnofacies of opportunistic association dominates. The Skolithos ichnofacies interpretation of abbreviation in Figure A: Ophiomorpha (O), Conichnus (C), Skolithos (Sk), Diplocraterion habichi (Dh), Roselia (R), Lingulichnus (Li), Arenicolites (Ar), Rhizocorrallium (Rh), Schaucylindrichnus (Sc), Fugichnia (Fu), Cylindrichnus (Cy), Bergaueria (Be), Gyrolithes (Gy), and Palaeophycus tubularis (Pt). For the Cruziana ichnofacies, the interpretation of abbreviations for Figure B are: Arenicolites (Ar), Skolithos (Sk), Diplocraterion habichi (Dh), Rhizocorrallium $(R h)$, Ophiomorpha $(O)$, Phycosiphon $(P h)$, Siphonichnus $(S i)$, Planolites $(P)$, Psammichnites $(P s)$, Thalassinoides $(T h)$, Rhizocorrallium (Rh), Zoophycos (Z), Palaeophycus heberti (Pa), Rusophycus (Ru), Teichichnus (Te), Rosselia socialis (Rs), Conichnus (C), Cruziana (Cr), Phoebichnus (Pb), Lockeia (Lo), Helminthopsis (H), Fugichnia (Fu), Chondrites ( $\mathrm{Ch})$, and Cylindrichnus $(\mathrm{Cy})$.

by organisms, coupled with heterogeneous distribution of cements (Figure 25). Such observation in thin-sections signifies that petrography should not be overlooked as a useful technique in assessing reservoir quality in sediments; although, due to over reliance on wire-line log analysis and other large-scale methods of reservoir evaluation, petrography seems to be overlooked [135]. Evidently, petrography offers a microscopic opportunity to assess reservoir characteristics, albeit, not possible by large-scale assessment methods [135]. 


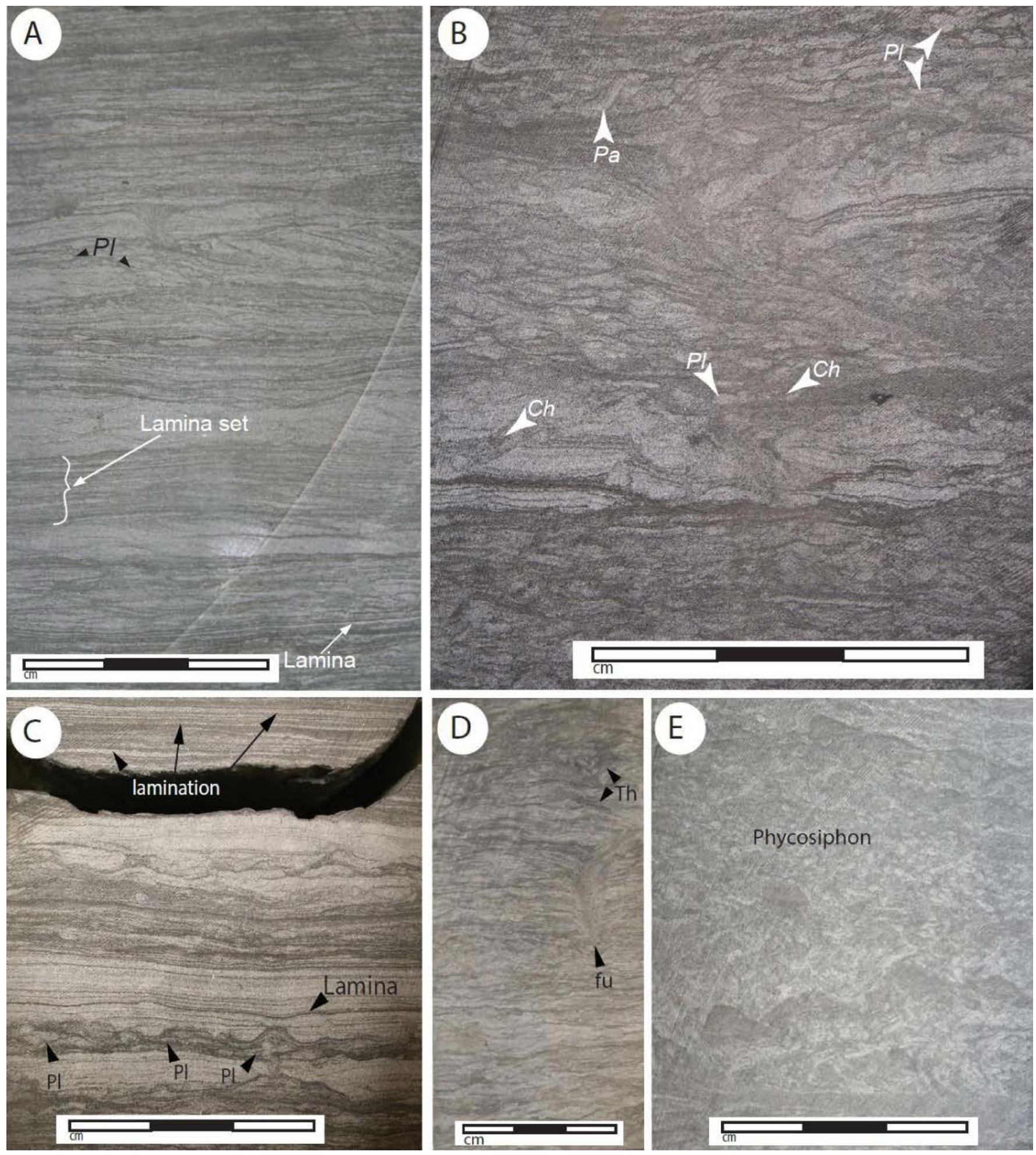

Figure 21. (A) Laminated very fine-grained sandstone and coarse siltstone with Planolites (PI); (B) the lower part of the core is cryptically bioturbated with poor preservation of biogenic structures. The upper part of the core is bioturbated with trace fossils such as Palaeophycus $(P a)$, Phycosiphon (Ph), Planolites $(P I)$, and Chondrites $(C h) ;(\mathrm{C})$ laminated siltstone interbedded with very fine-grained sandstone; (D) laminated siltstone interbedded with very fine-grained sandstone. Fugichnia (fu) and Thalassinoides (Th) are present; (E) cryptically bioturbated silty-sandstone with Phycosiphon ( $P h)$. 

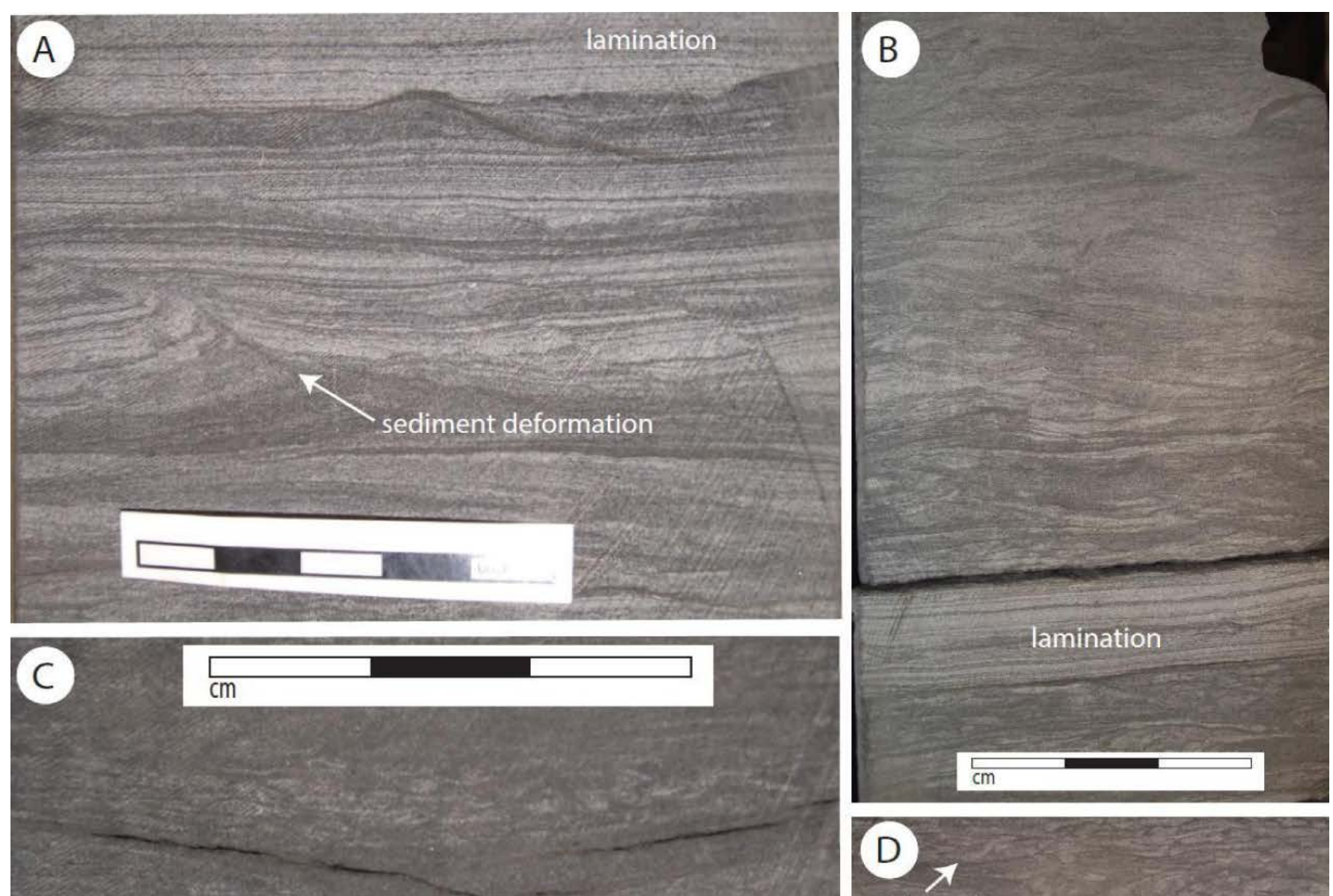

Palaeophycus

\section{fugichnia}
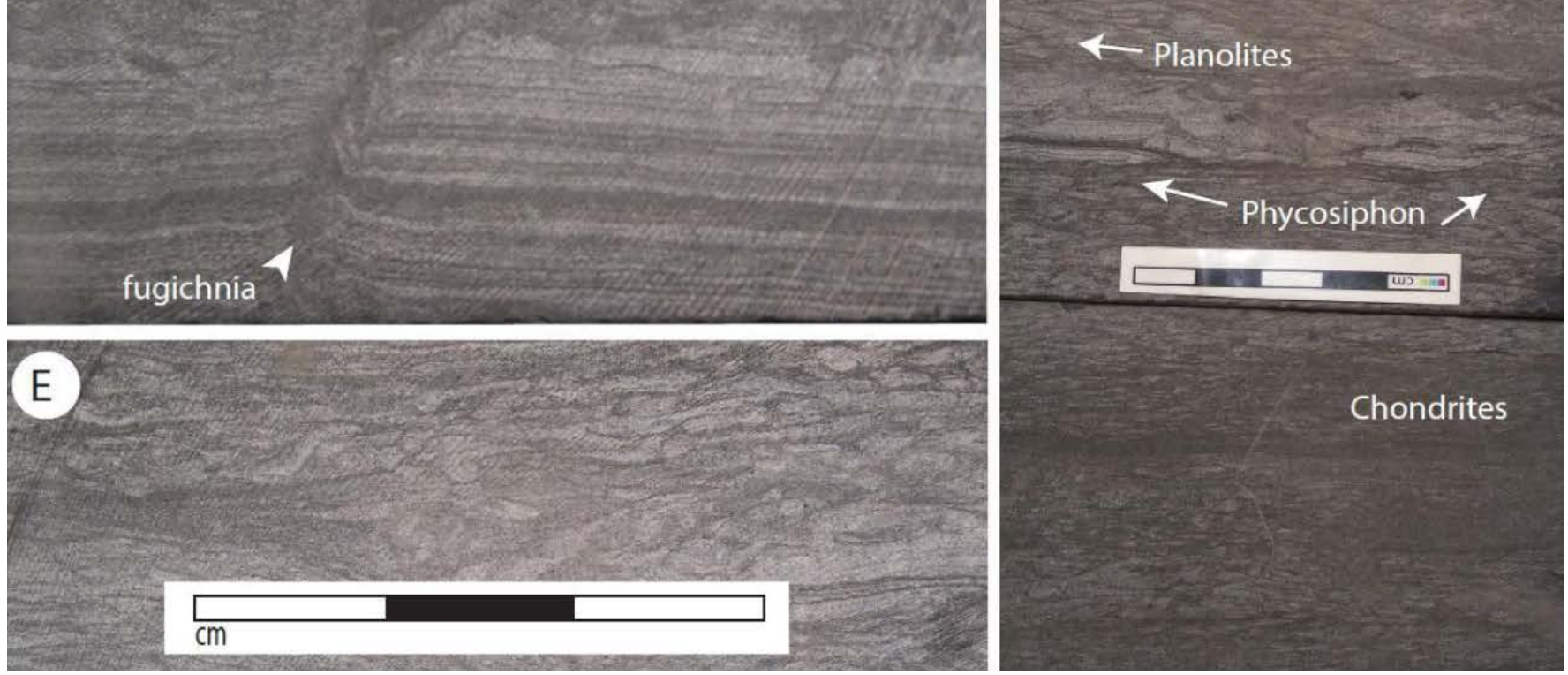

Figure 22. Shows Lithofacies F-3A trace fossils. (A) Laminated very fine-grained sandstone and coarse siltstone (well: A-20-H/93-P-9; depth: $2465.2 \mathrm{~m}$ ); (B) very fine-grained sandstone (well: d-21-G/93-P-9; depth: $2528.5 \mathrm{~m}$ ); (C) shows lamination and fugichnia (fu) (well: d-21-G/93-P-9; depth: $2541 \mathrm{~m}$ ); (D) shows trace fossils such as Planolites (PI), Chondrites (Ch), and Palaeophycus (Pa) (well: d-21-G/93-P-9; depth: 2527.3m); (E) shows Planolites (PI), Chondrites (Ch), and Palaeophycus (Pa). 

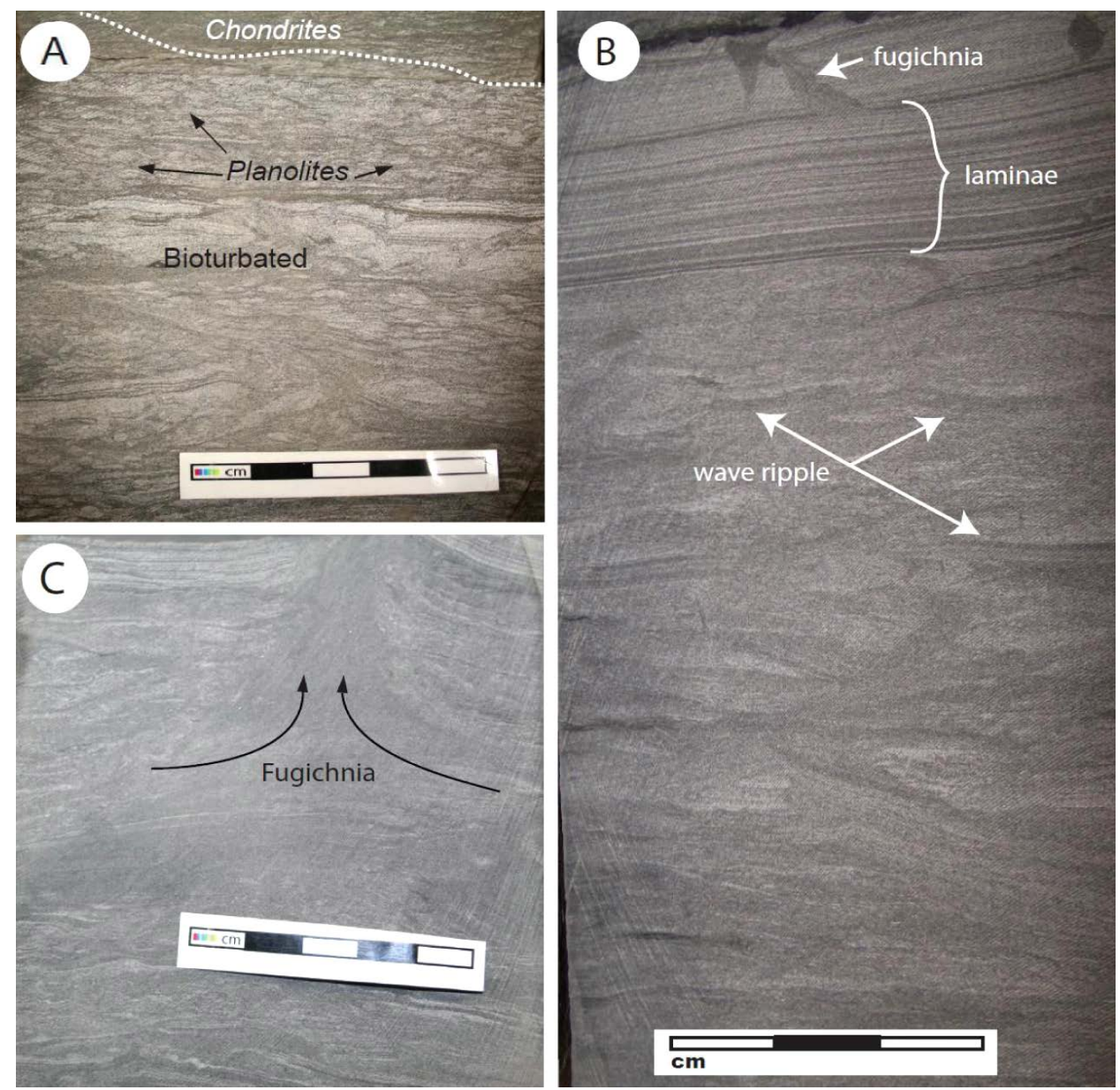

Figure 23. Shows depositional characteristics of Lithofacies F-3. (A) Shows bioturbated Lithofacies F-3 by Planolites and Chondrites (well: d-21-G/93-P-9; depth: $2534 \mathrm{~m}$ ); (B) shows wave ripple, and lamination (well: 9-29-79-14W6; depth: $1967 \mathrm{~m}$ ); (C) shows fugichnia, "escape trace" formed as a result of infauna attempt to escape burial during high, episodic sedimentation (well: 9-29-79-14W6; depth: $1984 \mathrm{~m}$ ).

Based on the present of Skolithos ichnofacies in Lithofacies F-3A, the depositional characteristics corresponds to the lower shoreface depositional environment [34]. Thus, the bioturbated very fine-grained sandy-siltstone of Lithofacies of F-3A is assigned to the Skolithos ichnofacies and interpreted herein as a deposit in the lower shoreface environment.

\subsubsection{Lithofacies F-3B Description: Cruziana Ichnofacies}

Lithofacies F-3B is composed of bioturbated siltstone dominated by Cruziana ichnofacies. The trace fossils recorded in Lithofacies F-3B are rare Zoophycos? Planolites, Phycosiphon, Chondrites, Thalassinoides, Cruziana, Skolithos, Teichichnus, and Palaephycos (Figure 20). In some cores, these traces are not well preserved, but appeared as cryptic bioturbation. The grain-size of lithofacies F-3B is moderately well sorted. Sedimentary structures in lithofacies F-3B include sediment deformation and fugichniaescape structures. 

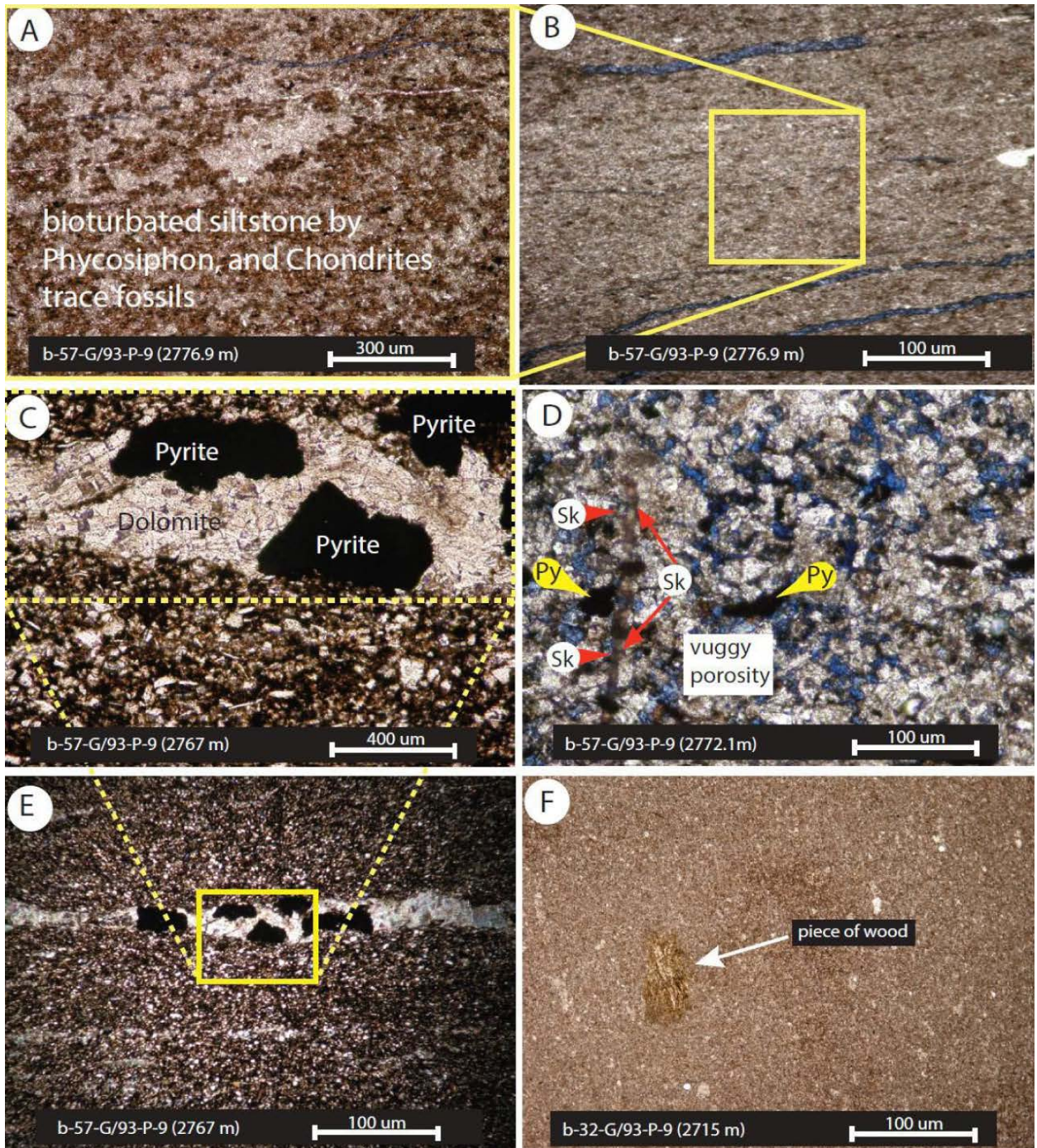

Figure 24. Microphotographs showing textural and mineralogical characteristics of Lithofacies F-3 of the Montney Formation in the Fort St. John study area, eastern north British Columbia. ((A) and (B)) Dolomitic silty-sandstone, bioturbated by Phycosiphon and Chondrites trace fossils; ((C) and (E)) shows pyritized detrital dolomite in a silty-sandstone matrix; (D) shows vuggy porosity associated with bioturbation. Skolithos (Sk) trace fossil is identified in thin-section in Plate D, and pyrite as "py"; (F) shows very fine-grained siltstone with preserved wood/plant material indicating continental provenance.

\subsubsection{F-3B Interpretation}

Trace fossils such as Planolites, Thalassinoides, Cruziana, and Palaeophycus are ichnocoenosis of the Cruziana ichnofacies [34]. The generalized ichnogenera attributed to the Cruziana ichnofacies is shown in Figure 20 and Figure 21. The Cruziana ichnofacies is commonly characterized by a high diversity of trace fossils (Figure 20) associated with a variety of ichnofauna [136] [137]. Cruziana expressions of distal proximal offshore environment are transitional between distal expression of the Skolithos ichnofacies and the archetypal Cruziana ichnofacies [34]. Distal expressions of the Cruziana ichnofacies are associated with muddy siltstone, silty mudstone, reflecting a soft, cohesive 


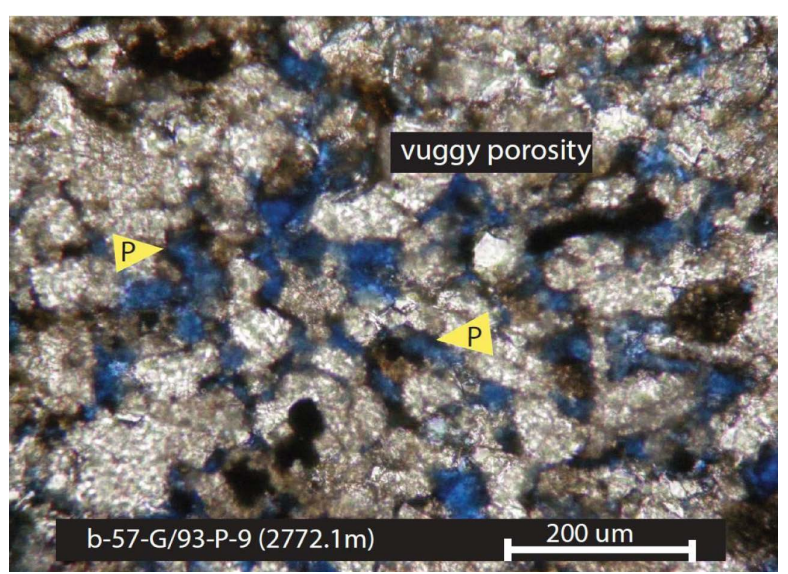

Figure 25. Microphotograph showing dolomitic siltstone facies and the associated vuggy porosity resulting from dissolution of material. Yellow arrow labeled " $\mathrm{P}$ " is pointing to vuggy porosity.

substrate under persistent quiescent fully marine condition [44], which is the case in Lithofacies F-3B. Lithofacies F-3B shows an increased proportion of Phycosiphon, Planolites, Thalassinoides, Chondrites and rare Zoophycos? which reflects a basinward ichnofacies. Thus, the present of these trace fossils in Lithofacies F-3B are indicative of distal offshore setting. Facies associated with rapid deposition rates are usually characterized by reduction in bioturbation intensity [34] [138]. Ichnofauna associated with such deposits are those showing escape behavior structure such as fugichnia (Figure 23(C)), and simple feeding structures, persistently high rate of deposition or event sedimentation results in low biodiversity and sparse ichnological imprint. Indications of rapid, episodic, or seismically generated tempestites ( small scale $=\mathrm{cm}$ ) in Lithofacies F-3B are suggested by the presence of finer-grained sand overlying siltstone, fluid escape structures, and soft sediment deformation. Such episodic or event deposition typically results in reduced or non-bioturbation due to insufficient time for endobenthic fauna to recolonize the tempestite substrate [34]. Commonly known Cruziana ichnofacies are those with deeply penetrating dwelling structures (e.g. Thalassinoides, Ophiomorpha) and rapidly adjusting structures (e.g. Diplocraterion, Teichichnus), intrabasinal feeding structures (e.g. Planolites, Macaronichnus) and escape structures tend to be the most common elements in the suites characteristic to rapid sedimentation [34]. The dwelling structures trace fossils, feeding structures traces, and rapidly adjusting structures occur as mono-specific ichnogenera with poor diversity in Lithofacies F-3B.

Based on the above sedimentological and ichnofacies characteristics of Lithofacies F-3B, it is interpreted as a deposition in a distal offshore setting (Figure 12).

\subsubsection{Lithofacies F-4 Description: Dolomitic Very Fine-Grained Sandstone}

Lithofacies F-4 consists of dolomitic, thin beds $(\leq 1 \mathrm{~m})$ of very fine-grained sandstone reoccurring as facies association throughout the entire successions in the logged cores (Figures 8-10). Thin-section petrography confirms that Lithofacies F-4 is quartz rich, moderately well sorted and dolomitic. Bioturbation and sedimentary structures are not present in lithofacies association F-4. In general, Lithofacies F-4 succession shows a 
coarsening upward trend. The basal contact of lithofacies F-4 with Lithofacies F-5 is sharp and grades into coarse siltstone grade.

\subsubsection{F-4 Interpretation}

The coarsening-upward trend in Lithofacies F-4 is interpreted as basinward shoreline shift, which often characterizes a progradational trend [139] [140]. The coarsening upward succession of Lithofacies F-4 is likely to have accumulated in deepening water, particularly in areas that are not adjacent to the shoreline [141] [142], and are characteristic of facies that prograded basinward during a falling stage of regression [139]. Based on depositional characteristics of Lithofacies F-4, it is interpreted herein as a deposition in proximal offshore depositional environment (Figure 12). The proximal offshore is characterized by storm wave base, immediately seaward of the lower limit of minimum fairweather wave base, where offshore processes operate continually.

\subsubsection{Lithofacies F-5 Description: Massive Siltstone}

Lithofacies F-5 is composed of dolomitic dark grey to black colored, organic rich, pyritized, massive siltstone (Figure 26). Petrographic examination of Lithofacies F-5 confirm the present of dolomite, quartz grains that are sub-angular to sub-rounded, and pyrite (Figures 27(A)-(D)). The texture of pyrite in Lithofacies F-5 under reflected light microscopy appears as irregularly rounded "clots" that partly coalesce with one another and partly separated by non-reflective dolomite (Figure 27(B)). SEM analysis of Lithofacies F-5 further shows that mineralogy comprises clay (smectite, illite, dickite, and palygorskite), and detrital dolomite (Figure 27(E) and Figure 27(F)). The observed palygorskite only occur in one sample and more analysis will help to establish how widely distributed palygorskite is in Lithofacies F-5. X-ray diffraction (XRD) analysis shows a spectrum and arrays of major and accessory minerals in Lithofacies F-5, which further confirm the present of dolomite, pyrite, and in addition, shows mica, and Albite. Bioturbation are not present in Lithofacies F-5. The basal contact of Lithofacies F-5 with Lithofacies F-4 is sharp. The upper contact of Lithofacies F-5 in some succession is sharp and erosionally demarcated from the overlying Doig Formation by an erosional lag deposit (Figure 26(D)).

\subsubsection{F-5 Interpretation}

The dark grey to black colored, organic carbon content of Lithofacies F-5 is a result of high nutrient rich sediment source and rapid sedimentation, which enhanced the preservation of organic matter [47], in oxygen-poor depositional environment [47] [48] [52] [54] [142], where density or temperature stratified water column form, typically below wave-base [47]. Oxygen-depleted environment is characteristic of a distal offshore setting [52] [54] [55]. The organic carbon richness of Lithofacies F-5 implies that F-5 is a potential hydrocarbon source rock.

Pyrite in Lithofacies F-5 is related to post-depositional emplacement caused by the dissolution of organic matter due to diagenesis (Figure 27(D)). Pyrite is commonly associated with organic rich sediments, such as black shales, and has been interpreted as 

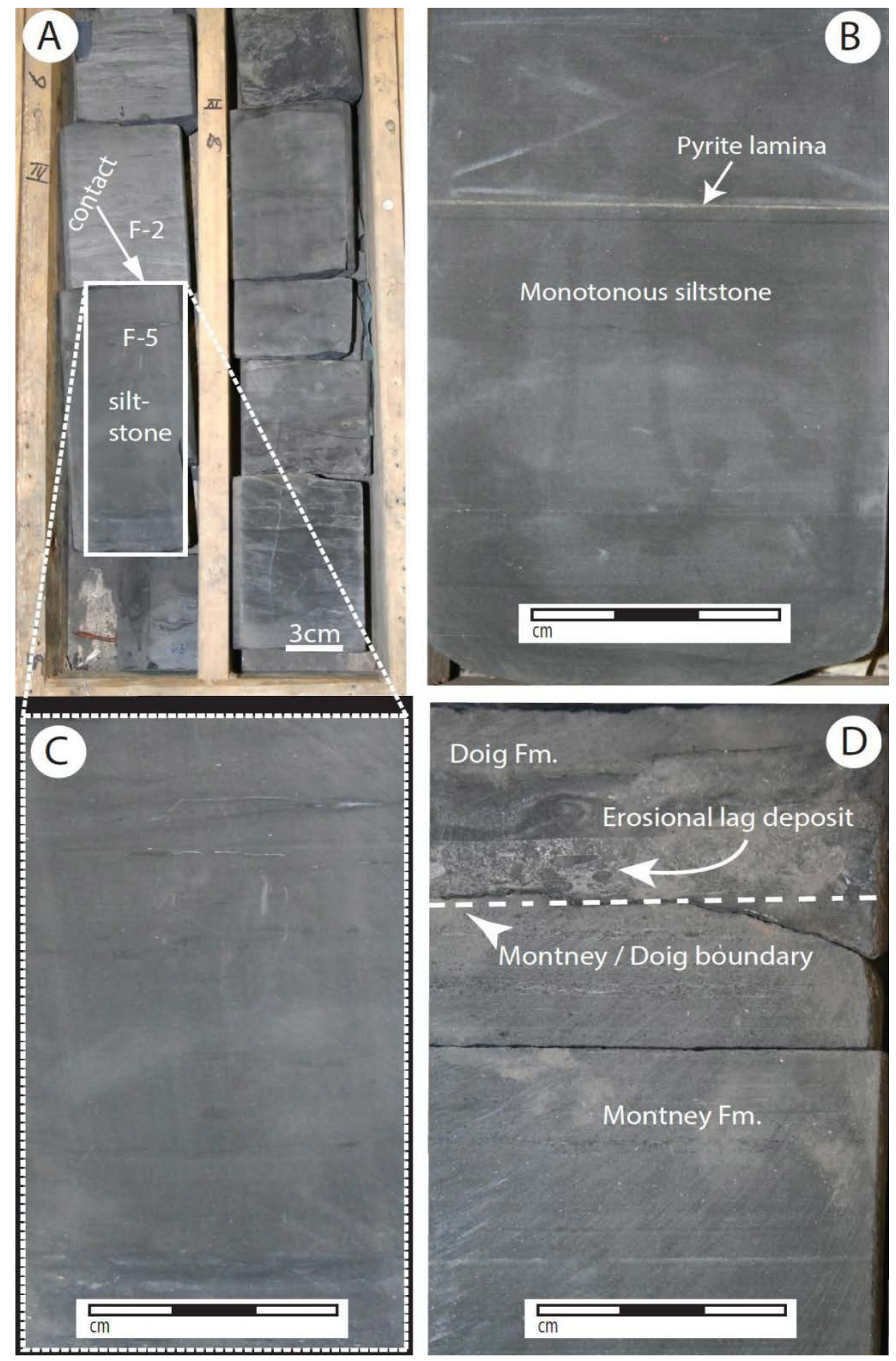

Figure 26. Shows massive siltstone of Lithofacies F-5. (A) Shows inset for plate C. Illustration shows the sharp facies contact between F-5 and F2 (well: 8-22-82-20-W6; depth: 1817.5); (B) massive siltstone with pyrite lamina (well: a-39-F/93-P-9; depth: $2455 \mathrm{~m}$ ); (C) shows magnification of plate A. Illustration shows massive siltstone (well: 8-22-82-20-W6; depth: $1817.5 \mathrm{~m}$ ); (D) shows massive siltstone and erosional lag deposit, and facies contact along the Montney Fm./ Doig Fm. boundary (well: d-39-F/93-P-9; depth: 2652.5 m). 

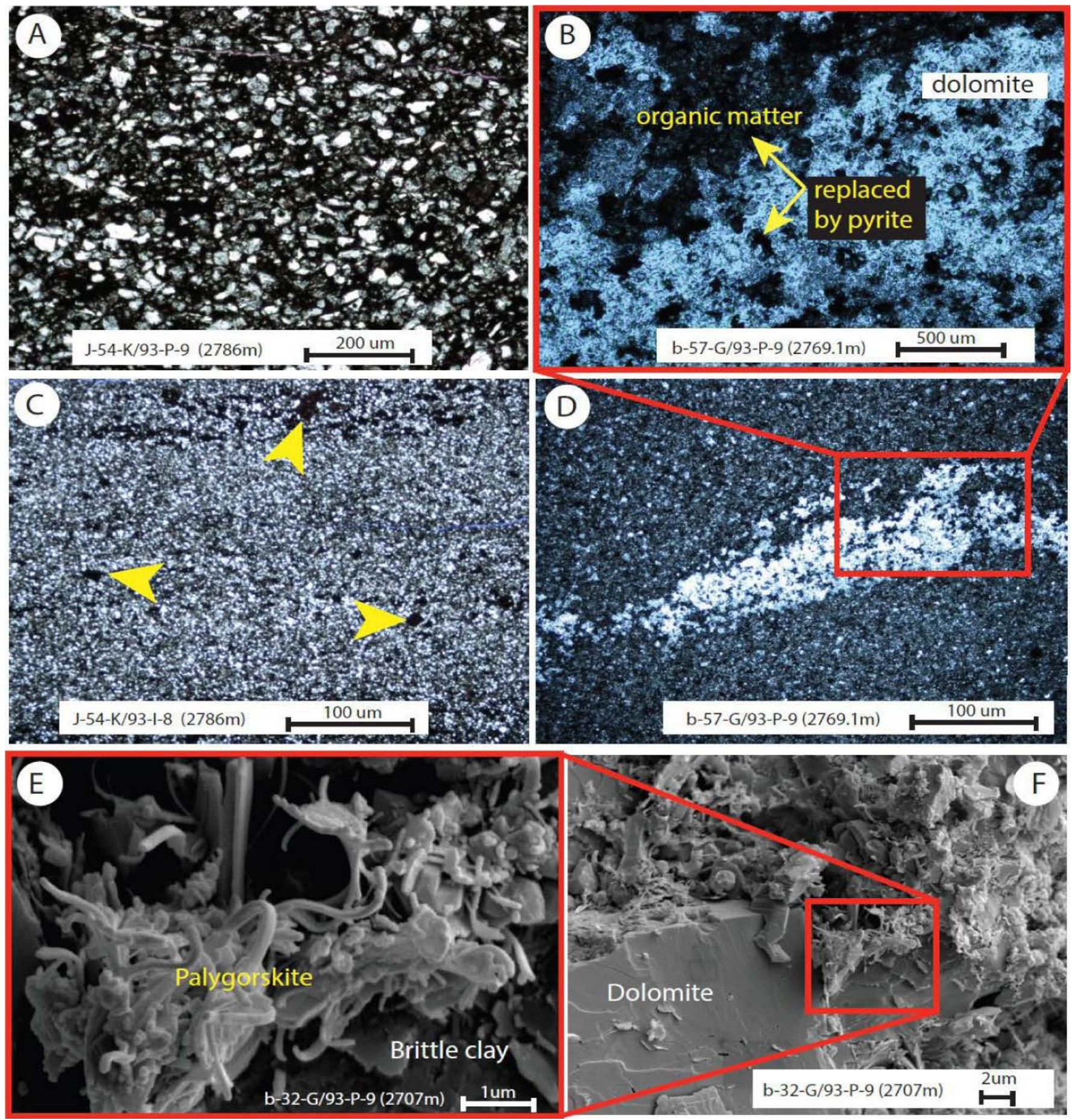

Figure 27. Shows microphotographs of scanning electron microscopy (SEM) and petrography of lithofacies of the Montney Formation. The textural characteristics are exemplified. (A) Angular to sub-angular grains, quartz rich, well sorted. (B) Pyritic sandstone, sub-rounded grains, and moderately well sorted; (B) shows magnification of plate D. Illustration shows dolomite, and pyritized, organic carbon rich siltstone. Pyrite replaces organic matter during diagenensis; (C) shows siltstone and some pyrite; (D) shows inset for plate B. Illustration shows dolomitic siltstone that have been pyritized due to diagenesis; (E) shows magnification of plate F. Illustration shows very well formed palygorskite clay, a form of clay mineral growth, derived from the transformation of illite to dickite, and further transformation of dickite to palygorskite due to diagenesis (severe temperature and pressure); (F) shows inset for plate E. Illustration shows dolomite, quartz, illite, dickite and palygorskite clay. 
concretionary in origin [143]. Localized pyrite concentrations in sediments are formed under fully anoxic conditions, due to an excess of $\mathrm{H} 2 \mathrm{~S}$ in the sediment from iron that was released from terrigenous grains, thereby causing precipitation in the form of disseminated tiny iron sulfide grains [143]. Accumulation of localized pyrite is related to anoxic organic-rich sediments, which is typically in a non-sulfidic surface layer [144]. In such environmental settings, iron oxyhydroxide coatings on terrigenous grains of the surface sediment readily source and solubilized iron that keeps pore waters free of $\mathrm{H} 2 \mathrm{~S}$ via pyrite formation [144] [145]. Contemporaneously, bacterial decay of organic matter becomes a mechanism of diffusing oxygen from the pore waters [143]. Under the ensuing combination of anoxic and non-sulfidic conditions, [143] argued that iron should be able to migrate through the sediment, making possible the localized accumulation of pyrite. This phenomenon produces various kinds of pyrite aggregates commonly present in organic rich black shales [143]. Morphologically, pyrites can be described as pyrite nodules, pyrite laminae, pyritized burrows, pyritized fossils [143], or nucleated pyrite [142]. Pyrite is an important diagenetic mineral and their present in a sample can help define the diagenetic history of sediments [131]. Therefore, the occurrence of pyrite in Lithofacies F-5 is a strong evidence of post depositional changes, and interpreted herein to have formed in-situ during diagenesis. Similarly, the present of detrital dolomite in Lithofacies F-5 is interpreted as post-depositional in origin, rather than in-situ [133]. Clay mineral in Lithofaciesis F-5 is associated with the organic carbon richness. [56] study the relationship between organic matter and shale in modern sediments and found that adsorption of carbon compounds onto clay mineral surfaces played a fundamental role in the burial and preservation of total organic carbon in the sediment. This evidence proved that organic matter are within the smectite interlayers of clay, which implies that hydrocarbon prone source rock may be closely related to clay mineralogy [56]. The depositional mechanism of the silt-sized grains and clay in lithofacies F-5 may be related to flocculation of fines due to the affinity of mica mineral as a major component of siliciclastics sediments, which is particularly more associated with silts and very fine-grained sediments [27].

[145] observed that the distance of transport of clay rich sediments affects clay mineral composition, thus they differ from one depositional environment to another (e.g., coastal clay mineral differs from continental slope clay mineral). The observation of [145] shows that chlorite proportion of clay mineral increase from the lower slope to upper slope, corresponding with a decrease in the proportion of smectite. The illite component of clay reaches its maximum on the middle slope [145]. Differential proportion of clay in the different depositional environment may be due to different mineral grain-sizes that characterize different depositional settings, and the different affinities to flocculation effects associated with deposition of hemipelagic [145]. The illitic/ palygorskite clay in lithofacies F-5 (Figure 27(E) and Figure 27(F)) has significant interpretation in relation to petrogenesis of the Montney Formation. [145] stated that kaolinite tends to flocculate near the river mouths, whereas illite (Figure 27(E) and Figure 27(F)) and montmorillonite (smectite) are transported further offshore, thus, 
supporting a distal depositional environment interpretation for Lithofacies F-5. [146] [147] [148] have reported similar depositional environment based on clay mineralogy. The X-ray diffraction response of illite (clay mineral) coupled with SEM image is an indication of the diagenesis, and low-grade metamorphic history of a sedimentary rock [149] [150] [151] [152]. Kaolinite is transformed to illite during diagenesis, typically at temperatures of $212^{\circ}-230^{\circ} \mathrm{F}\left(100^{\circ} \mathrm{C}-110^{\circ} \mathrm{C}\right)$ [153] [154]. The transformation of illite clay to dickite, and further transformation to palygorskite clay (Figure 27(E) and Figure 27(F)), supports the interpretation of diagenesis in lithofacies F-5. The clay associated with lithofacies F-5 is interpreted as post depositional in origin based on the diagenetic transformation of illite clay to palygorskite clay (Figure 27(E) and Figure 27(F)). [154] have reported that post-depositional origin is one of the ways clay minerals in sediments are derived, or by diagenetic modification. The absent of bioturbation in Lithofacies F-5 imply stressed and anaerobic conditions in restricted or oxygen poor environment [54] [55] [56] [57] [58] [80] [82]. Thus, lithofacies F-5 deposition may be related to pelagic processes. Pelagic depositional process is supported by the absence of depositional features characteristic of shoreface environment, such as storm or wave generated primary sedimentary structures (cross bedding, or hummocky cross stratification). The absence of trace fossils in lithofacies F-5 may be due to dysaerobic or oxygenation stress [33] [34] [49] [84] [85].

The upper contact of lithofacies F-5 of the Montney Formation with the overlying Doig Formation is reminiscent of erosional lag deposit characterized by a Glossifungites-Trypanites surface [19] [20] [83]. The mechanics of the deposition of rip-up clast of pebble sized to very coarse-grained sandstone, erosional disconformity that mark the boundary between the Montney and Lower Doig formations is interpreted to be akin to upper flow regime. The deposition of massive siltstone of Lithofacies F-5 may be related to transport and deposition from suspension, principally enhanced by the influence of waves mobilization of sediment by hyperpycnal mechanisms [58] [59] [60] [61]. As hyperpycnal flow gradually loses competence, part of its suspended load progressively settle from suspension seaward, the finer-grained silt-sized particles are deposited in distal offshore environments [64], where changes in bottom-water anoxia and suspension sediments settling from buoyant plumes mostly dominate [62]. The initial entrainment of sediments into suspension in the surf zone is due to turbulence, convection and eddy currents [155] [156]. As sediments goes beyond shoreface environment, energy start to dwindle and coarser grain-size begin to fall off from suspension and are deposited, while finer grains (silt-size) particles continue in suspension basinward. [155] [156] reported that gravity waves contribute significantly to the entrainment and transport of sediment, by enhancing near-bed velocities. [157] [158] proved with field measurement that turbulence are significantly responsible for sediments suspension in hydrodynamic flows. Siltstone deposit commonly occurs in a variety of depositional settings where energy and hydrodynamic processes are subtle and quiescent. Lithofacies F-5 massive siltstone was deposited by hydrodynamic processes related to settling of silt size particles through the water column. The organic rich nature of Lithofacies F-5 
suggests pelagic or hemipelagic processes commonly associated with distal settings. Based on the sedimentological and mineralogical characteristics of Lithofacies F-5 as described above, it is interpreted herein, as a deposition in a distal offshore (outer shelf) depositional environment to ramp setting.

\section{Hydrocarbon Potential of the Montney Formation}

Analyses of the Total Organic Carbon (TOC), S2, OI, HI and Tmax of the Montney Formation shows variably source rock richness, hydrocarbon generating potential with a Type III/IV and subordinate Type II kerogen. These parameters altogether indicate that the Triassic Montney Formation has good source rock richness (Figure 28) and thermal maturity is within gas generating window based on Tmax and vitrinite reflectance data (Figure 28, Figure 29). Rock Eval result coupled with porosity observed in this study has significant implication for reservoir quality and hydrocarbon production in the Montney Formation in northeastern British Columbia where isopach map and stratigraphic thickness range from $200 \mathrm{~m}$ to $320 \mathrm{~m}$ (Figure 6). The observed porosity on a thin-section (micron scale), shows that the porosity is associated with: 1) dissolution of organic matter or dolomitic material during diagenesis; 2) bioturbationenhanced porosity resulting from burrows by organisms; and 3) fracture porosity along bedding planes. [131] [159] have shown that reservoir enhancement in unconventional thinly bedded, silty to muddy lithologies that often characterizes permeability of unconventional reservoir can be enhanced by the activity of burrows.

\section{Conclusions}

The Montney Formation in northeastern British Columbia is a thick succession of siltstone, and very fine-grained sandstone. The facies of the Montney Formation are characterized by sedimentary structures such as lamination, soft sediment deformation,

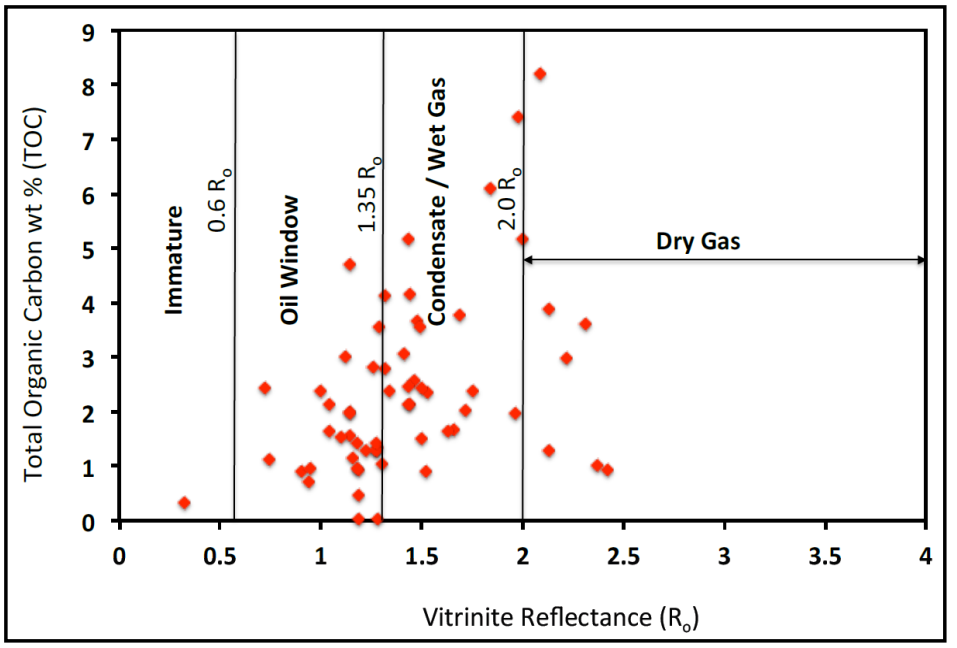

Figure 28. Total Organic carbon (TOC) vs. vitrinite reflectance (Ro) showing the thermal maturity of the Montney Formation source rock, and hydrocarbon generating phases in the Montney Formation sediments from study area, northeastern British Columbia. 


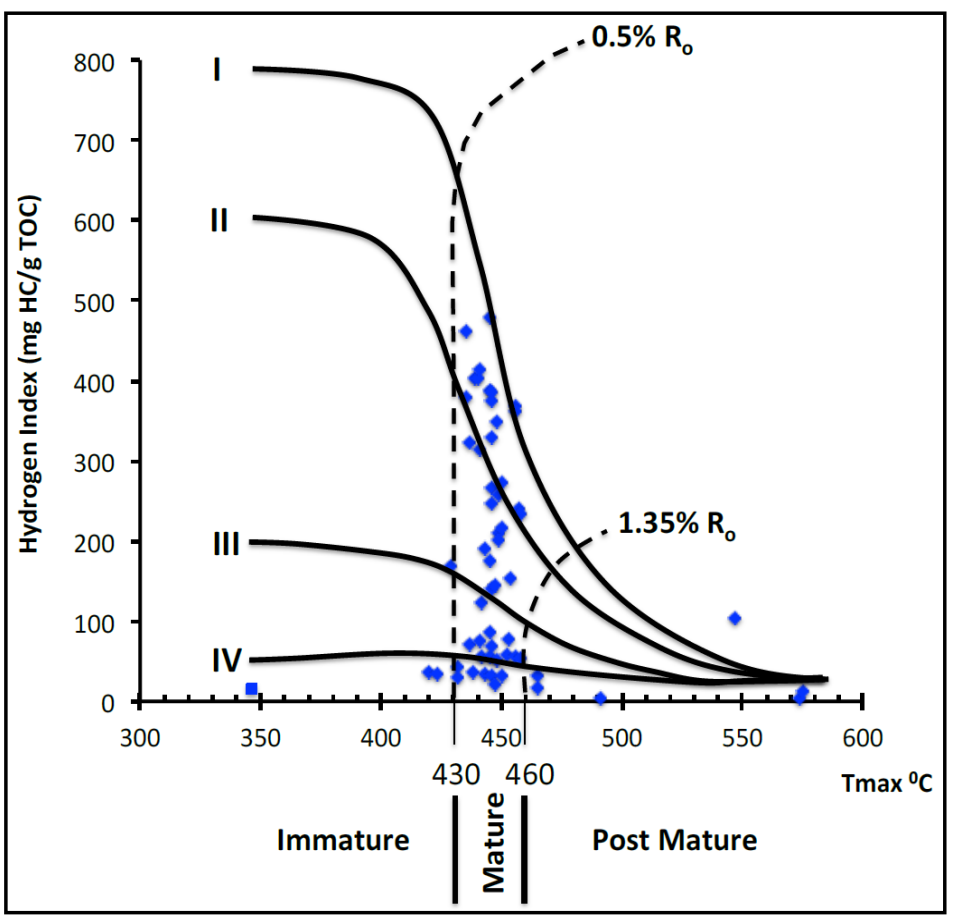

Figure 29. Thermal maturity of the Montney Formation determined with Tmax and vitrinite reflectance (Ro). The dotted line (Ro) is vitrinite reflectance calibrated with Tmax. This shows that the Montney Formation in northeastern British Columbia is extensively matured.

convolute lamination/bedding, current ripples, and infauna escape traces. The Montney Formation lithology is primarily composed of interbeded siltstone and very fine-grained, and interlaminated silty-sandstone. The Montney Formation in the study area is interpreted as deposition in the lower shoreface through proximal offshore to distal offshore settings.

Although trace fossils were not in abundance in the study area, however, infauna/ biodiversity was relatively high and represent ichnocoenoses attributed to the Skolithos and Cruziana ichnofacies. The low diversity of indigenous infauna, support the hypothesis of dysoxic depositional conditions in the lower Montney Formation during the Griesbachian time [4]. The ichnofauna records in the study area are mostly associated with lithofacies F-3, which is divided into Lithofacies F-3A and F-3B as the Skolithos ichnofacies and Cruziana ichnofacies respectively. The basis of this subdivision was to differentiate the Skolithos ichnofacies from the archetypal Cruziana ichnofacies. There was considerable diversity of ichnofauna traces in lithofacies F-3, except for monospecific genera, and similarly, abundance of ichnogenera was low. The recorded trace fossils are Chondrites, Planolites Montanus, Skolithos linearis, Thalassinoides, Teichichnus, Phycosiphon, Palaeophycus, and very rare Zoophycos? The escape traces (fugichnia) were very common in most cores logged in the study area. The morphology of fugichnia is akin to the shape of chevron pattern, typically showing an upward direction the organism tunneled through in responds to sudden, episodic, or high sedimentation events. Planolites was the most pervasive and abundant in the cores from the 
study area.

The impoverished trace fossils in lithofacies of the Montney Formation may be due to dysaerobic or oxygenation stress [34] [46] [48] [82] [83]. Dysoxic conditions prevailed for most of the Permian-Triassic (P-T) boundary that caused mass extinction, which ravaged biotic communities, the most severe in Earth's history [15] [84] [90], due to unequalled decline in the amount of dissolved oxygen in the world's oceans [86] [87] [88]. The anoxic conditions extended intermittently into shallow marine (proximal shelf) depositional settings [4] [49] [89], which have been reported to be associated with global anoxic conditions that subsequently caused a prolonged faunal recovery in the aftermath of Permian-Triassic biota crises [85] [90]. The protracted fauna recovery continued into the Lower and Middle Triassic time [4], thereby delaying fauna revitalization for several millions of years following the fauna mass extinction [49] [91] [92]. The harsh environmental conditions post $\mathrm{P}-\mathrm{T}$ fauna environmental crises have implications for the non-fossiliferous, or the non-evidence of fauna traces in lithofacies association F-1. The delayed recovery of biota communities obstructed diversification of species as well as prolonged elevated extinction levels that continued into the earliest Triassic [4], causing a depressed biota habitat for much of the Lower Triassic [85]. The harsh environmental conditions have implications for the non-fossiliferous, or the impoverished nature of trace fossils in facies from the Montney Formation.

Hydrocarbon reservoir potential in the Montney Formation assessed using RockEval data shows that the source rock is rich in organic matter, has thermal maturity that lies within gas generating window, and primarily a gas prone Type III/Type IV with subordinate Type II kerogen. Mineralogical composition of the Montney Formation consists of dolomite, quartz, calcite, plagioclase, clay (Illite/smectite), mica, K-feldspar, and pyrite [22].

\section{Acknowledgements}

The Faculty of Graduate Studies and Research, University of Alberta is thanked for scholarship funding and for providing a conducive academic environment that enhanced the completion of this research in the department of Earth and Atmospheric Sciences. Geoscience B.C is appreciated for awarding scholarship funding in unconventional hydrocarbon reservoir research in British Columbia, which supported this work. Drs. Murray Gingras and Jonh-Paul Zonneveld are both thanked for funding this research.

\section{References}

[1] Edwards, D.E., Barclay, J.E., Gibson, D.W., Kvill, G.E. and Halton, E. (1994) Triassic Strata of the Western Canada Sedimentary Basin. Geological Atlas of Western Canada (Chapter 16): Calgary, Canadian Society of Petroleum Geologists/Alberta Research Council, 257-275.

[2] Podruski, J.A., Barclay, J.E., Hamblin, A.P., Lee, P.J., Osadetz, K.G., Procter, R.M. and Taylor, G.C. (1988) Conventional Oil Resources of Western Canada. Geological Survey of Canada Paper, 149 p.

[3] Gibson, D.W and Edwards, D.E. (1990) An Overview of Triassic Stratigraphy and Deposi- 
tional Environments in the Rocky Mountain Foothills and Western Interior Plains, Peace River Arch Area. Bulletin of Canadian Petroleum Geology, 38A, 146-158.

[4] Zonneveld, J-P., Gingras, M.K. and Beatty, T.W. (2010) Diverse Ichnofossil Assemblages Following the P-T Mass Extinction, Lower Triassic, Alberta and British Columbia, Canada: Evidence for Shallow Marine Refugia on the Northwestern Coast of Pangaea. Palaios, 25, 368-392. https://doi.org/10.2110/palo.2009.p09-135r

[5] Davies, G.R. (1997) The Triassic of the Western Canada Sedimentary Basin: Tectonic and Stratigraphic Framework, Paleogeography, Paleoclimate and Biota. Bulletin of Canadian Petroleum Geology, 45, 434-460.

[6] Orchard, M.J. and Tozer, E.T. (1997) Triassic Conodont Biochronology, Its Calibration with the Ammonoid Standard, and a Biostratigraphic Summary for Western Canada Sedimentary Basin. Bulletin of Canadian Petroleum Geology, 45, 675-692.

[7] Reidiger, C.L., Fowler, M.G., Brooks, P.W. and Snowdon, L.R. (1990) Triassic Oils and Potential Mesozoic Source Rocks, Peace River Arch Area, Western Canada Basin. Organic Geochemistry, 16, 295-305. https://doi.org/10.1016/0146-6380(90)90049-6

[8] Milelli, S. (2013) New Report Doubles Previous Estimates of Montney Formation Natural Gas Reserves in British Columbia and Alberta. Canadian Energy Perspectives, Development in Energy and Law, 14 November 2013. http://www.canadianenergylawblog.com/2013/11/14/new-report-doubles-previous-estimat es-of-montney-formation-natural-gas-reserves-in-british-columbia-and-alberta/

[9] Egbobawaye, E.I., Zonneveld, J.-P. and Gingras, M.K. (2010) Tight Gas Reservoir Evaluation in Montney and Lower Doig Formations, Northeastern British Columbia, Western Canada. American Association of Petroleum Geologists Abstract, 19, 66-67.

[10] Egbobawaye, E.I., Gingras, M.K. and Zonneveld, J.-P. (2011) The Geochemistry of the Montney and Lower Doig Tight Gas Reservoir, Northeastern British Columbia. American Association of Petroleum Geologists Abstract, No. 90124.

http://www.searchanddiscovery.com/abstracts/html/2011/annual/abstracts/Egbobawaye.ht ml?q=\%2BtextStrip\%3Aegbobawaye

[11] Gibson, D.W. and Barclay, J.E. (1989) Middle Absaroka Sequence, the Triassic Stable Craton. In: Ricketts, B.D., Ed., Western Canada Sedimentary Basin: A Case History, Canadian Society of Petroleum Geologists, 219-231.

[12] Tozer, E.T. (1982) Marine Triassic faunas of North America: Their Significance for Assessing Plate and Terrane Movements. Geologische Rundschau, 71, 1077-1104. https://doi.org/10.1007/BF01821119

[13] Henderson, C.M. (1997) Uppermost Permian Conodont and Permian-Triassic Boundary in the Western Canada Sedimentary Basin. Bulletin of Canadian Petroleum Geology, 45, 693-707.

[14] Porter, J.W., Price, R.A. and McCrossan, R.G. (1982) The Western Canada Sedimentary Basin. Philosophical Transactions of the Royal Society of London, A305, 169-182. https://doi.org/10.1098/rsta.1982.0032

[15] Zonneveld, J.-P. (2011) Suspending the Rules: Unraveling the Ichnological Signature of the Lower Triassic Post-Extinction Recovery Interval. Palaios, 26, 677-681. https://doi.org/10.2110/palo.2011.S06

[16] Kump, L.R., Pavlov, A. and Arthur, M.A. (2005) Massive Release of Hydrogen Sulfide to the Surface Ocean and Atmosphere during Intervals of Oceanic Anoxia. Geology, 33, 397-400. https://doi.org/10.1130/G21295.1

[17] Luo, G., Wang, Y., Yang, H., Algeo, T.J., Kump, L.R., Huang, J. and Xie, S. (2011) Stepwise 
and Large-Magnitude Negative Shift in $\delta^{13} \mathrm{C}$ carb Preceded the Main Marine Mass Extinction of the Permian-Triassic Crisis Interval. Palaeogeography, Palaeoclimatology, Palaeoecology, 299, 70-82. https://doi.org/10.1016/j.palaeo.2010.10.035

[18] Armitage, J.H. (1962) Triassic Oil and Gas Occurences in the Triassic Charlie Lake Formation, Northeastern British Columbia, Canada. Journal of the Alberta Society of Petroleum Geologists, 10, 35-56. http://archives.datapages.com/data/cspg/data/010/010002/0035.htm

[19] Egbobawaye, E.I., Kravchinsky, V.A., Zonneveld, J.-P. and Gingras, M.K. (2011) Magnetostratigraphy Dating and Correlation of the Lower Doig and Upper Montney Formations (Lower Triassic), Northeastern British Columbia, Western Canada. Canadian Society of Petroleum Geologists, CSPG, CSEG, CWLS Convention Abstract, Calgary, 1-5.

[20] Wilson, N. and Zonneveld, J.-P. (2011) Transition of the Montney to Doig Formations; Subsurface to Outcrop Correlations. Northeastern British Columbia Unconventional Gas Forum Presentation, April 2011.

[21] Orchard, M.J. and Zonneveld, J.-P. (2009) The Lower Triassic Sulphur Mountain Formation in the Wapiti Lakearea: Lithostratigraphy, Conodont Biostratigraphy, and a New Biozonation for the Lower Olenekian (Smithian). Canadian Journal of Earth Sciences, 46, 757-790. https://doi.org/10.1139/E09-051

[22] Egbobawaye, E.I. (2016) Whole-Rock Geochemistry and Mineralogy of Triassic Montney Formation, Northeastern British Columbia, Western Canada Sedimentary Basin. International Journal of Geosciences, 7, 91-114. http://dx.doi.org/10.4236/ijg.2016.71008

[23] Moslow, T.F. and Davies, G.R. (1997) Turbidite Reservoir Facies in the Lower Triassic Montney Formation, WestCentral Alberta. Bulletin of Canadian Petroleum Geology, 45, 507-536.

[24] Habicht, J.K.A. (1979) Paleoclimate, Paleomagnetiam, and Continental Drift. AAPG Studies in Geology No. 9, American Association of Petroleum Geologists, Tulsa, 31 p.

[25] Barclay, J.E., Krause, F.F., Campbell, R.I. and Utting, J. (1990) Dynamic Casting and Growth Faulting: Dawson Creek Graben Complex, Carboniferous-Permian Peace River Embayment, Western Canada. In: O'Connell, S.C. and Bell, J.S., Eds., Geology of the Peace River Arch, Bulletin of Canadian Petroleum Geology, 38A, 115-145.

[26] Willis, A.J. (1992) Sedimentology and Stratigraphic Framework of the Middle Triassic Halfway Formation, Wembly Oil field, Alberta. Unpublished Master's Degree Thesis, University of Alberta, $412 \mathrm{p}$.

[27] Tucker, M. (1988) Techniques in Sedimentology. Willey-Blackwell Scientific Publisher, Boston, $393 \mathrm{p}$.

[28] Sorby, H.C. (1858) On the Microscopic Structure of Crystals, Indicating the Origin of Minerals and Rocks. Quarterly Journal of the Geological Society of London, 14, 453-500. https://doi.org/10.1144/GSL.JGS.1858.014.01-02.44

[29] Gressly, A. (1838) Observations géologiques sur le Jura soleurois. Nouveaux mémoires de la Société Helvetique des Sciences Naturelles. Neuchâtel, 2, 349 p.

[30] Reading, H.G. (1996) Sedimentary Environments and Facies. 3rd Edition, Blackwell Scientific Publications, Boston, 615 p.

[31] Miall, A.D. (1980) Cyclicity and the Facies Model Concept in Geology. Bulletin of Canadian Society of Petroleum Geologists, 28, 59-80.

[32] Cross, T.A. and Homewood, P.W. (1997) Amanz Gressly's Role in Founding Modern Stratigraphy. Geological Society of America Bulletin, 109, 1617-1630. https://doi.org/10.1130/0016-7606(1997)109<1617:AGSRIF>2.3.CO;2 
[33] Gingras, M.K., Barn, K.B., MacEachern, J.A. and Pemberton, S.G. (2005) Conceptual Framework for the Application of Trace Fossils. AAPG and SEPM Short Course Note, No. 52, 1-26.

[34] MacEachern, J.A., Pemberton, S.G., Bann, K.L. and Gingras, M.K. (2005) Departure from the Archetypal Ichnofacies: Effective Recognition of Physico-Chemical Stresses in the Rock Record. Applied Ichnology, Short Course Note No. 52, SEPM and CSPG, 2005. American Association of Petroleum Geologists Bulletin and SEPM Short Course Note, No. 52, 66-88.

[35] Sternberg, K.V. (1833) Versuch einer geognostisch-botanischen Darstellung der Flora der Vorwelt. Leip zig and Prague. In: On the Trace-Fossil Chondrites, 22, Part 4, 475-499.

[36] D’Orbigny, A. (1842) Voyage dans l'Amérique méridionale (le Brésil, la République oriental de l'Uruguay, la République Argentine, la Patagonie, la République du Chili, la République de Bolivia, la République du Péron) exécuté pendant les annees 1826, 1827, 1829, 1830, 1831, 1832, et 1833. Pitois-Levrault (Paris), Levrault (Strasbourg), 3(4) (Paléontologie), 188 p.

[37] Nicholson, H.A. (1873) Contributions to the Study of the Errant Annelids of the Older Paleozoic Rocks. Proceedings of the Royal Society of London, 21, 288-290. https://doi.org/10.1098/rspl.1872.0061

[38] Simpson, S. (1975) Classification of Trace Fossils. In: Frey, R.W., Ed., The Study of Trace Fossils, Springer-Verlag, New York, 39-54. https://doi.org/10.1007/978-3-642-65923-2_3

[39] Haldeman, S.S. (1840) Supplement to Number One of "A Monograph of the Limniades, or Freshwater Univalve Shells of North America”, Descriptions of Apparently New Animals in Different Classes, and the Names and Characters of the Subgenera in Paludina and Anculosa. In: Dobson, J., Ed., Philadelphia, 3 p.

[40] Reith, A. (1932) Neue Funde spongeliomorpher Fucoideen aus dem Jura Schwabens. Geologische und palaeontologische Abhandlungen, 19, 257-294.

[41] Seilacher, A. (1955) Spuren und Fazies im Un-terkambrium. In: Schinderwolf, O.H. and Seilacher, A., Eds., Beitrige zur Kenntnis des Kambriums in der Salt Range (Pakistan), Akademie der Wissenschaften und der Literatur zu Mainz, Mathematisch-naturwissenschaftliche Klasse, Abhandlungen, No. 10, 11-143.

[42] Von Fisher-Ooster, C. (1858) Die fossilen Fucoiden der Schweizer Alpen, nebst Erörterungen uber deren geologischen Alter. Huber, Bern, $72 \mathrm{p}$.

[43] Hall, J. (1847) Palaeontology of New York. Volume 1: Containing Descriptions of the Organic Remains of the Lower Division of the New York System (Equivalent to the Lower Silurian rocks of Europe). In: van Benthuysen, C., Ed., Paleontological Society, Albany, State of New York. 338 p.

[44] Pemberton, S.G. and Frey, R.W. (1982) Trace Fossil Nomenclature and the Planolites Palaeophycus Dilemma. Journal of Paleontology, 56, 843-881.

[45] Massalongo, A. (1855) Zoophycos, novum genus plantorum fossilium. Antonelli (Verona), 45-52.

[46] Reading, H.G. and Collinson, J.D. (1996) Clastic Coasts. Sedimentary Environments: Processes, Facies and Stratigraphy. Blackwells, Cornwall, 154-231.

[47] Muller, P.J. and Suess, E. (197) Productivity, Sedimentation Rate and Sedimentary Organic Matter in the Oceans-1. Organic Carbon Preservation. Deep-Sea Research, Pergamon Press Ltd., 26A, 1347-1362.

[48] Demaison, G.J. and Moore, G.T. (1980) Anoxic Environments and Oil Source Rock Bed Genesis. American Association of Petroleum Geologists Bulletin, 64, 1179-1209. 
[49] Ekdale, A.A. (1985) Trace Fossils and Mid-Cretaceous Anoxic Events in the Atlantic Ocean. In: Curran, H.A., Ed., Biogenic Structures: Their Use in Interpreting Depositional Environments, SEPM Special Publication, 333-342. https://doi.org/10.2110/pec.85.35.0333

[50] Wignall, P.B. and Twitchett, R.J. (2002b) Extent, Duration, and Nature of the Permian-Triassic Superanoxic Event. In: Koeberl, C. and MacLeod, K.C., Eds., Catastrophic Events and Mass Extinctions. Impacts and Beyond: Geological Society of America Special Paper 356, 393-413.

[51] Tyson, R.V. and Pearson, T.H. (1991) Modern and Ancient Continental Shelf Anoxia: An Overview. In: Tyson, R.V. and Pearson, T.H., Eds., Modern and Ancient Continental Shelf Anoxia: Geological Society of London Special Publication 58, 1-24. https://doi.org/10.1144/gsl.sp.1991.058.01.01

[52] Wignall, P.B. and Hallam, A. (1992) Anoxia as a Cause of the Permian/Triassic Mass Extinction: Facies Evidence from Northern Italy and the Western United States. Palaeogeography, Palaeoclimatology, Palaeoecology, 93, 21-46. https://doi.org/10.1016/0031-0182(92)90182-5

[53] Bentley, S.J. and Nitouer, C.A. (1999) Physical and Biological Influences on the Formation of Sedimentary Fabric in an Oxygen-Restricted Depositional Environment: Eckernförde bay, Southwestern Baltic Sea. Palaios, 14, 585-600. https://doi.org/10.2307/3515315

[54] Ekdale, A.A. and Mason, T.R. (1988) Characteristic Trace-Fossil Associations in Oxygen-Poor Sedimentary Environments. Geology, 16, 720-723. https://doi.org/10.1130/0091-7613(1988)016<0720:CTFAIO >2.3.CO;2

[55] Houseknecht, D.W. and Schenk, C.J. (2004) Sedimentology and Sequence Stratigraphy of the Cretaceous Nanushuk, Seabee, and Tuluvak Formations Exposed on Umiat Mountain, North-Central Alaska. US Geological Survey Professional Paper 1709-B, 1-18.

[56] Kennedy, M.J., Pevear, D.R. and Hills, R.J. (2002) Mineral Surface Control of Organic Carbon in Black Shale. Science, 295, 657-660. https://doi.org/10.1126/science.1066611

[57] Schieber, J., and Southard, J.B. (2009) Bedload Transport of Mud by Floccule Ripples-Direct Observation of Ripple Migration Processes and Their Implications. Geological Society of America, 37, 483-486. https://doi.org/10.1130/g25319a.1

[58] Stow, D.A.V., Reading, H.G. and Collison, J.D. (2002) Deep Seas. In: Reading, H.G., Ed., Sedimentary environments: Processes, Facies, and Stratigraphy, Blackwell Science, Oxford, 395-453.

[59] Milliman, J.D. and Meade, R.H. (1983) World-Wide Delivery of River Sediment to the Oceans. Journal of Geology, 91, 1-21. https://doi.org/10.1086/628741

[60] Wright, L.D., Yang, Z.-S., Bornhold, B.D., Keller, G.H., Prior, D.B. and Wiseman Jr., W.J. (1986) Hyperpycnal Plumes and Plume Fronts over the Huanghe (Yellow River) Delta Front. Geo-Marine Letters, 6, 97-105. https://doi.org/10.1007/BF02281645

[61] Wiseman Jr., W.J., Fan, Y-B., Bornhold, B.D., Keller, G.H., Su, Z.-Q., Prior, D.B., Yu, Z.-X., Wright, L.D., Wang, F.-Q. and Qian, Q.-Y. (1986) Suspended Sediment Advection by Tidal Currents off the Huanghe (Yellow River) Delta. Geo-Marine Letters, 6, 107-113. https://doi.org/10.1007/BF02281646

[62] Ghadeer, S.G. and Macquaker, J.H.S. (2011) Sediment Transport Processes in an Ancient Mud-Dominated Succession: A Comparison of Processes Operating in Marine Offshore Settings and Anoxic Basinal Environments. Journal of Geological Society of London, 168, 1121-1132. https://doi.org/10.1144/0016-76492010-016

[63] Pedersen, G.K. (1985) Thin, Fine-Grained Storm Layers in a Muddy Shelf Sequence: An Example from the Lower Jurassic in the Stenlille 1 Well, Denmark. Journal of Geological 
Society of London, 142, 357-374. https://doi.org/10.1144/gsjgs.142.2.0357

[64] Berthault, G. (1988) Experiments on Lamination of Sediments. EN Tech. Journal, 3, 25-29. http://www.creationontheweb.com/images/pdfs/tj/j03_1/j03_1_025-029.pdf

[65] Thomas, S.G., Fielding, C.R. and Frank, T.D. (2007) Lithostratigraphy of the Late Early Permian (Kungurian) Wandrawandian Siltstone, New South Wales: Record of glaciation? Australian Journal of Earth Sciences, 54, 1057-1071. https://doi.org/10.1080/08120090701615717

[66] Bridge, J.S. (1981) Hydraulic Interpretation of Grain-Size Distributions Using a Physical Model for Bedload Transport. Journal of Sedimentary Petrology, 51, 1109-1124. https://doi.org/10.1306/212F7E37-2B24-11D7-8648000102C1865D

[67] Middleton, G.V. (1976) Hydraulic Interpretation of Sand Size Distributions. The Journal of Geology, 84, 405-426. https://doi.org/10.1086/628208

[68] Folk, R.L. and Ward, W.C. (1957) Brazos River Bar: A Study in the Significance of Grain Size Parameters. Journal of Sedimentary Petrology, 27, 3-26. https://doi.org/10.1306/74D70646-2B21-11D7-8648000102C1865D

[69] Blott, S.J. and Pye, K. (2001) Gradistat: A Grain Size Distribution and Statistics Package for the Analysis of Unconsolidated Sediments. Earth Surface Processes and Landforms, 26, 1237-1248. https://doi.org/10.1002/esp.261

[70] Bagnold, R.A. (1956) The Flow of Cohesionless Grains in Fluids. Transaction Royal Society of London, 249, 235-297. https://doi.org/10.1098/rsta.1956.0020

[71] Visher, G.S. (1969) Grain Size Distributions and Depositional Processes. Journal of Sedimentary Petrology, 39, 1074-1106.

[72] Kuenen, P.H.H. (1959) Experimental Abrasion: Fluviatile Action on Sand. American Journal of Science, 257, 172-190. https://doi.org/10.2475/ajs.257.3.172

[73] Kuenen, P.H.H. (1969) Origin of Quartz Silt. Journal of Sedimentary Petrology, 39, 16311633. https://doi.org/10.1306/74D71ED3-2B21-11D7-8648000102C1865D

[74] Riezebos, P.A. and van der Waals, I. (1974) Silt-Sized Quartz Particles: A Proposed Source. Sedimentary Geology, 12, 279-285. https://doi.org/10.1016/0037-0738(74)90022-0

[75] Moss, A.J. and Green, P. (1975) Sand and Silt Grains: Predetermination of Their Formation and Properties by Microfractures in Quartz. Journal of the Geological Society of Australia, 22, 485-495. https://doi.org/10.1080/00167617508728913

[76] Blatt, H. (1970) Determination of Mean Sediment Thickness in the Crust: A Sedimentologic Method. Geological Society of America, 81, 255-262. https://doi.org/10.1130/0016-7606(1970)81[255:DOMSTI]2.0.CO;2

[77] Blatt, H. (1987) Oxygen Isotopes and the Origin of Quartz. Journal of Sedimentary Petrology, 57, 373-377. https://doi.org/10.1306/212F8B34-2B24-11D7-8648000102C1865D

[78] Droppo, I.G. (2001) Rethinking What Constitutes Suspended Sediment. Hydrological Processes, 15, 1551-1564. https://doi.org/10.1002/hyp.228

[79] Schieber, J., Southard, J.B. and Thaisen, K. (2007) Accretion of Mudstone Beds from Migrating Floccule Ripples. Science, 318, 1760-1763. https://doi.org/10.1126/science.1147001

[80] Rhoads, D.C. and Morse, J.W. (1971) Evolutionary and Environmental Significance of Oxygen-Deficient Martine Basins. Lethaia, 4, 413-428. https://doi.org/10.1111/j.1502-3931.1971.tb01864.x

[81] Byers, C.W. (1977) Biofacies Patterns in Euxinic Basins: A General Model. In: Cook, H.E., and Enos, P.E., Eds., Deep-Water Carbonate Environments, Society of Economic Paleon- 
tologists and Mineralogists Special Publication 25, 5-17. https://doi.org/10.2110/pec.77.25.0005

[82] Savrda, C.E., Bottjer, D.J. and Gorsline, D.S. (1984) Development of a Comprehensive Oxygen-Defficienty Marine Biofacies Model: Evidence from Santa Monica, San Pedro, and Santa Barbara Basins, California Continental Borderland. American Association of Petroleum Geologists Bulleyin, 68, 1179-1192.

[83] Egbobawaye, E.I. (2013) Tight Gas Reservoir Characterization in Montney Formation, Northeastern British Columbia, Western Canada. Unpublished Ph.D. Thesis, Department of Earth and Atmospheric Sciences, University of Alberta, Edmonton, 431 p.

[84] Burnett, C.W. (1977) Geochemistry and Origin of Phosphorite Deposits from off Peru and Chile. Bulletin of Geological Society of America, 88, 813-823. https://doi.org/10.1130/0016-7606(1977)88<813:GAOOPD >2.0.CO;2

[85] Bentor, Y.K. (1980) Phosphorites-The Unsolved Problems. In: Bentor, Y.K., Ed., Marine Phosphates, Special Publication of Society of Economic Paleontology and Mineralogy, Tulsa, 29, 3-18. https://doi.org/10.2110/pec.80.29.0003

[86] Raup, D.M. (1979) Size of the Permo-Triassic Bottleneck and Its Evolutionary Implications. Science, 206, 217-218. https://doi.org/10.1126/science.206.4415.217

[87] Erwin, D.H., Bowring, S.A. and Jin, Y.G. (2002) End-Permian Mass Extinctions: A Review. In: Koeberl, C. and MacLeod, K.G., Eds., Catastrophic Events and Mass Extinction: Impacts and Beyond, Geological Society of America Special Paper, 356, 363-383.

https://doi.org/10.1130/0-8137-2356-6.363

[88] Twitchett, R.J. (1999) Palaeoenvironments and Faunal Recovery after the End-Permian Mass Extinction. Palaeogeography, Palaeoclimatology, Palaeoecology, 154, 27-37. https://doi.org/10.1016/S0031-0182(99)00085-1

[89] Isozaki, Y. (1997) Permo-Triassic Boundary Superanoxia and Stratified Superocean: Records from lost Deep Sea. Science, 276, 235-238.

https://doi.org/10.1126/science.276.5310.235

[90] Grice, K., Cao, C., Love, G.D., Böttcher, M.E., Twitchett, R.J., Grosjean, E., Summons, R.E., Turgeon, S.C., Dunning, W. and Yugan, J. (2005) Photic Zone Euxinia during The Permian-Triassic Superanoxic Event. Science, 307, 706-709.

https://doi.org/10.1126/science.1104323

[91] Berner, R.A., Vandenbrooks, J.M. and Ward, P.D. (2007) Oxygen and Evolution. Science, 316, 557-558. https://doi.org/10.1126/science.1140273

[92] Hallam, A. (1991) Why Was There a Delayed Radiation after the End-Paleozoic Extinction? Historical Biology, 5, 257-262. https://doi.org/10.1080/10292389109380405

[93] Erwin, D.H. (1993) The Great Paleozoic Crisis: Life and Death in the Permian. Columbia University Press, New York, 327 p.

[94] Hallam, A. (1995) The Earliest Triassic as an Anoxic Event, and Its Relationship to the End-Paleozoic Mass Extinction. Canadian Society of Petroleum Geologists Memoir, 17, 797-804.

[95] Wignall, P.B. and Twitchett, R.J. (2002) Oceanic Anoxia and the End Permian Mass Extinction. Science, 272, 1155-1158. https://doi.org/10.1126/science.272.5265.1155

[96] Twitchett, R.J. and Wignall, P.B. (1996) Trace Fossils and the Aftermath of the Permo-Triassic Mass Extinction: Evidence from Northern Italy. Palaeogeography, Palaeoclimatology, Palaeoecology, 124, 137-151. https://doi.org/10.1016/0031-0182(96)00008-9

[97] Twitchett, R.J., Krystyn, L., Baud, A., Wheeley, J.R. and Richoz, S. (2004) Rapid Marine 
Recovery after the End-Permian Mass-Extinction Event in the Absence of Marine Anoxia. Geology, 32, 805-808. https://doi.org/10.1130/G20585.1

[98] Eyles, C.H., Eyles, N. and Gostin, V.A. (1998) Facies and Allostratigraphy of High-Latitude, Glacially Influenced Marine Strata of the Early Permian Southern Sydney Basin, Australia. Sedimentology, 45, 121-161. https://doi.org/10.1046/j.1365-3091.1998.00138.x

[99] Davies, G.R., Moslow, T.F. and Sherwin, M.D. (1997) The Lower Triassic Montney Formation, West-Central Alberta. Bulletin of Canadian Petroleum Geology, 45, 474-505.

[100] McKee, E. and Weir, G.W. (1953) Terminology for Stratification and Cross-Stratification in Sedimentary Rocks. Geological Society of America Bulletin, 64, 381-390. https://doi.org/10.1130/0016-7606(1953)64[381:TFSACI]2.0.CO;2

[101] Cheel, R.J. and G.V. (1986) Middleton, Horizontal Lamination Formed under Upper Flow Regime Plane Bed Conditions. Journal of Geology, 94, 489-504. https://doi.org/10.1086/629053

[102] Poala, C., Wiele, S.M. and Reinhart, M.A. (1989) Upper-Regime Parallel Lamination as the Result of Turbulent Sediment Transport and Low-Amplitude Bedforms. Sedimentology, 36, 47-60. https://doi.org/10.1111/j.1365-3091.1989.tb00819.x

[103] Johnson, H.D and Baldwin, C.T. (2002) Shallow Clastic Seas. In: Reading, H.G., Ed., Sedimentary Environments. Processes, Facies, and Stratigraphy, Blackwell Science, Oxford, 232-279.

[104] Weise, B.R. (1980) Wave-Dominated Delta Systems of the Upper Cretaceous San Miguel Formation, Maverick Basin, South Texas. Bureau of Economic Geology, Report of Investigations, 107, Austin, Texas, 33 p.

[105] Harms, J.C., Southard, J.B. and Walker, R.G. (1982) Structure and Sequence in Clastic Rocks. Lecture Notes: Society of Economic Paleoleontologist and Mineralogists Short Course No. 9, Calgary, 7.7.2. https://doi.org/10.2110/scn.82.09

[106] Arnold, K.J. (1994) Origin and Distribution of Aeolian Sandstones in the Triassic Charlie Lake Formation, Northeastern British Columbia. Unpublished M.Sc. Thesis, University of Alberta, Edmonton, 320 p.

[107] MacEachern, J.A. (1994) Ichnology of Viking and Peace River formations, Alberta. Unpublished Ph.D. Thesis, University of Alberta, Edmonton, 617 p.

[108] Collinson, J., Mounney, J.N. and Thompson, D. (2006) Sedimentary Structures. 3rd Edition. Terra Publishing, England, 292 p. https://www.amazon.com/Sedimentary-Structures-Third-John-Collinson/dp/190354419X

[109] Moretti, M. (2000) Soft-Sediment Deformation Structures Interpreted as Seismites in Middle-Late Pleistocene Aeolian Deposits (Apulian Foreland, Southern Italy). Sedimentary Geology, 135, 167-179. https://doi.org/10.1016/S0037-0738(00)00070-1

[110] Bhattacharya, H.N. and Bandyopadhyay, S. (1998) Seismites in a Proterozoic Tidal Succession, Singhbhum, Bihar, India. Sedimentary Geology, 119, 239-252. https://doi.org/10.1016/S0037-0738(98)00051-7

[111] Allen, J.R.L. (1986) Earthquake Magnitude-Frequency, Epicentral Distance and Soft Sediment Deformation in Sedimentary Basins. Sedimentary Geology, 46, 67-75. https://doi.org/10.1016/0037-0738(86)90006-0

[112] Allen, J.R.L. (1982) Sedimentary Structures: Their Character and Physical Basis. Elsevier, New York, 2, 663.

[113] Owen, G. (1987) Soft-Sediment Deformation in Upper Proterozoic Torridonian Sandstones (Applecross Formation) at Torridon, Northwest Scotland. Journal of Sedimentary Research, 
A65, 495-504.

[114] Wittenberg, J. and Moslow, T.F. (1991) Origin and Variability of Overthickened Sandstone in the Doig Formation, West-Central Alberta. Canadian Society of Petroleum Geologists, Calgary, 146.

[115] Cant, D.J. (1984) Possible Syn-Sedimentary Tectonic Controls on Triassic Reservoirs, Halfway and Doig, Charlie Lake Formations, West-Central. Canadian Society of Petroleum Geologists, Calgary, 45.

[116] Cant, D.J. (1986) Hydrocarbon Trapping in the Halfway Formation (Triassic), Wembly Field, Alberta. Bulletin of Canadian Petroleum Geology, 34, 329-338.

[117] Beranek, L.P. and Mortensen, J.K. (2006) A Triassic Link between Yukon-Tanana and North America; New Detrital Zircon Age, Geochemical, and Biostratigraphic Data. Geological Society of America, Cordilleran Section, Abstracts with Program, 38, 5-6.

[118] Ferri, F. and Zonneveld, J.-P. (2008) Were Triassic Rocks of the Western Canada Sedimentary Basin Deposited in a foreland? Canadian Society of Petroleum Geologists Reservoir, 35, 12-14.

[119] Stewart, A.D. (1963) On Certain Slump Structures in the Torridonian Sandstones of Applocross. Geological Magazine, 100, 205-218. https://doi.org/10.1017/S0016756800055151

[120] Selley, R.C. (1969) Torridonian Alluvium and Quick Sands. Scottish Journal of Geology, 5, 328-346. https://doi.org/10.1144/sjg05040328

[121] William, G.E. (1969) Characteristics and Origin of a Precambrian Pediment. Journal of Geology, 77, 183-207. https://doi.org/10.1086/627421

[122] William, G.E. (1970) Origin of Disturbed Bedding in Torridon Group Sandstones. Scottish Journal of Geology, 6, 409-411. https://doi.org/10.1144/sjg06040409

[123] Ten Haaf, E. (1956) Significance of Convolute Lamination. Geology en Mijnbouw, 18, 188-194.

[124] Sanders, J.E. (1960) Origin of Convoluted Laminae. Geology Magazine, 97, 409-421. https://doi.org/10.1017/S0016756800061768

[125] Wall, B.R.G., Girbacea, R., Mesonjesi, A. and Aydin, A. (2006) Evolution of Fracture and Fault-Controlled Fluid Pathways in Carbonates of the Albanides Fold-Thrust Belt. American Association of Petroleum Geologists Bulletin, 90, 1227-1249. https://doi.org/10.1306/03280604014

[126] Reid, S.A. and McIntyre, J.L. (2001) Monterey Formation Porcelanite Reservoirs of the Elk Hills Field, Kern County, California. American Association of Petroleum Geologists Bulletin, 85, 169-189.

[127] MacKinnon, T.C. (1989) Petroleum Geology of the Monterey Formation in the Santa Maria and Santa Barbara Coastal and Offshore Areas. In: MacKinnon, T., Ed., Oil in the California Monterey Formation, Washington DC, American Geophysical Union, Field Trip Guidebook T311, 11-27. https://doi.org/10.1029/ft311p0011

[128] Burley, S.D. and Kantorowicz, J.D. (1986) Thin Section and S.E.M. Textural Criteria for the Recognition of Cement-Dissolution Porosity in Sandstones. Sedimentology, 33, 587-604. https://doi.org/10.1111/j.1365-3091.1986.tb00763.x

[129] Pitman, E.D. (1970) Plagioclase Feldspar as an Indicator of Provenance in Sedimentary Rocks. Journal of Sedimentary Petrology, 40, 591-598.

[130] Krynine, P.D. (1941) Triassic Sediments of Connecticut. Geological Society of America Bulletin, 52, 1919.

[131] Hudson, J.D. (1982) Pyrite in Ammonite-Bearing Shales from the Jurassic of England and 
Germany. International Association of Sedimentologists, 37, 639-667.

https://doi.org/10.1111/j.1365-3091.1982.tb00072.x

[132] England, G.L., Rasmussen, B., Krapez, B. and Groves, D.I. (2002) Palaeoenvironmental Significance of Rounded Pyrite in Siliciclastic Sequences of the Late Archean Witwatersrand Basin: Oxygen-Deficient Atmosphere or Hydrothermal Alteration? International Association of Sedimentologists, 49, 1133-1156.

[133] Bone, Y., James, N.P. and Kyser, T.K. (1992) Synsedimentary Detrital Dolomite in Quaternary Cool-Water Carbonate Sediments, Lacepede Shelf, South Australia. Geology, 20, 109-112. https://doi.org/10.1130/0091-7613(1992)020<0109:SDDIQC>2.3.CO;2

[134] Pemberton, S.G. and MacEachern, J.A. (2001) The Use of Trace Fossils in Sequence Stratigraphy, Exploration and Production Geology. Applied AAPG Short Course, 60.

[135] Gordon, J.B., Pemberton, S.G. and Gingras, M.K. (2010) Biogenically Enhanced Permeability: A Petrographic Analysis of Macaronichnus Segregatus in the Lower Cretaceous Bluesky Formation, Alberta, Canada. American Association of Petroleum Geologists Bulletin, 94, 1779-1795. https://doi.org/10.1306/04061009169

[136] Pemberton, S.G. and Frey, R.W. (1984) Ichnology of Storm-Influenced Shallow Marine Sequence: Cardium Formation (Upper Cretaceous) at Seebe, Alberta: In: Stott, D.F. and Glass, D.J., Eds., The Mesozoic of Middle North America, Canadian Society of Petroleum Geologists, Memoir 9, 281-300.

[137] Frey, R.W., Pemberton, S.G. and Saunders, T.D.A. (1990) Ichnofacies and Bathymetry: A Passive Relationship. Journal of Paleontology, 64, 155-157.

https://doi.org/10.1017/S0022336000042372

[138] Howard, J.D. (1975) The Sedimentological Significance of Tracefossils. In: Frey, R.W., Ed., The Study of Trace Fossils, New York Springer-Verlag, 131-146. https://doi.org/10.1007/978-3-642-65923-2_8

[139] Catuneanu, O. (2006) Principles of Sequence Stratigraphy (ed.). Elsevier, Oxford, 255.

[140] Naish, T. and Kamp, P.J.J. (1997) Foraminiferal depth Palaeoecology of Late Pliocene Shelf Sequences and Systems Tracts, Wanganui Basin, New Zealand. Sedimentary Geology, 110, 237-255. https://doi.org/10.1016/S0037-0738(96)00085-1

[141] Catuneanu, O., Willis, A.J. and Miall, A.D. (1998) Temporal Significance of Sequence Boundaries. Sedimentary Geology, 121, 157-178.

https://doi.org/10.1016/S0037-0738(98)00084-0

[142] Wishner, K., Levin, L., Gowing, M. and Mullineaux, L. (1990) Involvement of the Oxygen Minimum in Benthic Zonation on a Deep Seamount. Nature, 346, 57-58. https://doi.org/10.1038/346057a0

[143] Berner, R.A. (1981) A New Geochemical Classification of Sedimentary Environments. Journal of Sedimentary Petrology, 51, 359-366.

[144] Canfield, D.E., Raiswell, R. and Bottrell, S. (1992) The Reactivity of Sedimentary Iron Minerals toward Sulfide. American Journal of Science, 292, 659-683. https://doi.org/10.2475/ajs.292.9.659

[145] Einsele, G. (2000) Sedimentary Basins: Evolution, Facies, and Sediment Budget. Springer-Verlag, Berlin, Heidelberg, 791 p. https://doi.org/10.1007/978-3-662-04029-4

[146] Schieber, J. (2003) Simple Gifts and Buried Treasures-Implications of Finding Bioturbation and Erosion Surfaces in Black Shales. The Sedimentary Record, SEPM, 1, 4-8.

[147] Carson, B. and Arcaro, N.P. (1983) Control of Clay Mineral Stratigraphy by Selective Transport in Late Pleistocene-Holocene Sediments of Northern Cascadia Basin-Juan de 
Fuca Abyssal Plain: Implication for Studies of Clay Mineral Provenance. Journal of Sedimentary Petrography, 53, 395-406.

[148] Gibbs, R.J. (1985) Settling velocity, Diameter, and Density for Flocs of Illite, Kaolinite and Montmorillonite. Journal of Sedimentary Petrography, 55, 65-68.

[149] Lamy, F., Hebbeln, D. and Wefer, G. (1998) Terrigeneous Sediment Supply along the Chilean Continental Slope: Modern Latitudinal Trends of Texture and Composition. Geologische Rundschau, 87, 477-494. https://doi.org/10.1007/s005310050223

[150] Weaver, C.E. (1960) Possible Uses of Clay Minerals in the Search for Oil. AAPG Bulletin, 44, 1505-1518. https://doi.org/10.1016/b978-0-08-009351-2.50024-6

[151] Frey, M. (1970) The Step from Diagenesis to Metamorphism in Pelitic Rocks during Alpine Orogenesis. Sedimentology, 15, 261-279. https://doi.org/10.1111/j.1365-3091.1970.tb02189.x

[152] Gill, W.D., Khalaf, F.E. and Massoud, M.S. (1977) Clay Minerals as an Index of the Degree of Metamorphism of the Carbonate and Terrigeneous Rocks in the South Wales coalfield. Sedimentology, 39, 330-332.

[153] Stalder, P.J. (1970) Organic and Inorganic Metamorphism in the Taveyyannaz Sandstone of Swiss Alps and Equivalent Sandstones in France and Italy. Journal of Sedimentary Petrolo$g y, 49,463-482$.

[154] Burst, J.F. (1969) Diagenesis of Gulf Coast Clayey Sediments and Its Possible Relation to Petroleum Migration. American Association of Petroleum Geologists Bulletin, 53, 73-93.

[155] Hardy, R.G. and Turcker, M.E. (1988) X-Ray Power Diffraction of Sediments. In: Techniques in Sedimentology, Blackwell Scientific Publication, Oxford, 191-228.

[156] Shibayama, T., Higuchi, A. and Horikawa, K. (1986) Sediment Transport Due to Breaking Waves. Proc. 20th Coastal Engineering Conference, ASCE, 1509-1522.

[157] Smith, G.G. and Mocke, G.P. (2002) Interaction between Breaking/Broken Waves and Infragravity-Scale Phenomena to Control Sediment Suspension Transport in the Surfzone. Marine Geology, 187, 329-345. https://doi.org/10.1016/S0025-3227(02)00385-7

[158] Aagaard, T. and Greenwood, B. (1994) Sediment Transport by Wind Waves, Long Waves and Mean Currents: An Experiment on Nearshore Morphodynamics, Lake Huron, Canada. Coastal Dynamics, 14-28.

[159] Pemberton, S.G. and Gingras, M.K. (2005) Classification and Characterizations of Biogenically Enhanced Permeability. American Association of Petroleum Geologists Bulletin, 89, 1493-1517. 
Submit or recommend next manuscript to SCIRP and we will provide best service for you:

Accepting pre-submission inquiries through Email, Facebook, LinkedIn, Twitter, etc. A wide selection of journals (inclusive of 9 subjects, more than 200 journals)

Providing 24-hour high-quality service

User-friendly online submission system

Fair and swift peer-review system

Efficient typesetting and proofreading procedure

Display of the result of downloads and visits, as well as the number of cited articles

Maximum dissemination of your research work

Submit your manuscript at: http://papersubmission.scirp.org/

Or contact ijg@scirp.org 